\title{
Faith, power, and conflict: Miner preachers and the United Mine Workers of America in the Harlan County mine wars, 1931-1939
}

Carletta A. Bush

West Virginia University

Follow this and additional works at: https://researchrepository.wvu.edu/etd

\section{Recommended Citation}

Bush, Carletta A., "Faith, power, and conflict: Miner preachers and the United Mine Workers of America in the Harlan County mine wars, 1931--1939" (2006). Graduate Theses, Dissertations, and Problem Reports. 2503.

https://researchrepository.wvu.edu/etd/2503

This Dissertation is protected by copyright and/or related rights. It has been brought to you by the The Research Repository @ WVU with permission from the rights-holder(s). You are free to use this Dissertation in any way that is permitted by the copyright and related rights legislation that applies to your use. For other uses you must obtain permission from the rights-holder(s) directly, unless additional rights are indicated by a Creative Commons license in the record and/ or on the work itself. This Dissertation has been accepted for inclusion in WVU Graduate Theses, Dissertations, and Problem Reports collection by an authorized administrator of The Research Repository @ WVU.

For more information, please contact researchrepository@mail.wvu.edu. 
Faith, Power, and Conflict: Miner Preachers and the United Mine Workers of America in the Harlan County Mine Wars, 1931-1939

\author{
Carletta A. Bush \\ Dissertation submitted to the \\ Eberly College of Arts and Sciences \\ At West Virginia University \\ In partial fulfillment of the requirements \\ For the degree of \\ Doctor of Philosophy \\ In Modern American History \\ Ronald L. Lewis, Ph.D., chair \\ Elizabeth Fones-Wolf, Ph.D. \\ Kenneth Fones-Wolf, Ph.D. \\ John Super, Ph.D. \\ Dwight Billings, Ph.D. \\ Department of History \\ Morgantown, WV \\ 2006
}

Keywords: Kentucky, Harlan County, mine wars, miner preachers, Bloody Harlan, United Mine Workers of America, Church of God

Copyright 2006 Carletta A. Bush 


\section{ABSTRACT \\ Faith, Power, and Conflict: Miner Preachers and the United Mine Workers of America in the Harlan County Mine Wars, 1931-1939}

\section{Carletta A. Bush}

Early accounts of the Harlan County mine wars place the inability of the United Mine Workers of America (UMWA) to establish a permanent foothold in the county, first at the feet of of the Harlan County Coal Operators Association (HCCOA) and secondly at the worn work boots of miners who, when work was plentiful, saw little or no need for a union. The power of the HCCOA is not in question. Its members used their immense wealth and influence to build a million dollar war chest to fight the union and to maintain their iron-clad grip upon the county's political, judicial, and legal systems. In doing so, the association built such an impenetrable fortress around the county that without the assistance of the international UMWA and the protection of the federal government, local unionists were unable to maintain union recognition. The international UMWA abandoned the Harlan miners, not once, but twice during the 1930s. UMWA support for the Harlan miners might have evaporated, but the miners' desire for a union remained. In spite of the UMWA's lack of support, a group of miner/preachers secretly drummed up support for the union. The county's miners persisted in their demand for change in the work place and within the community with resources from a source regarded as an opiate of the people and a bulwark in the defense of the status quo-- their religion. The plain folk religion of the mountaineers, with its emphasis on the centrality of the Holy Spirit and literal interpretation of the Bible, empowered these miners. The power of the Holy Spirit empowered miners to preach the gospel of Jesus Christ and Unionism, and God's Word sanctified their revolution. These miner preachers and their churches provided more visible resources as well. Besides the leadership provided by miner preachers, these churches provided miners, regardless of race, ethnicity, or religious affiliation, with free spaces where they could gather to receive information, hold union meetings, political rallies, and establish aid distribution during strikes. Equally important was the plausibility of belief that resulted from the fellowship of believers, whether they were gathering for prayer meetings, worship services, or rallies. In all three cases, miner preachers stood in the pulpit, at the pit mouth, and on the picket line praying for victory and encouraging the weary to maintain their faith in God's Promises. In turn, their belief spread throughout the mining community and infected miners regardless of their religious orientation. These miner preachers and their churches provided the resources to support the desire for a union alive, recruit membership, and provide meeting places for local union meetings and rallies until the UMWA was firmly established in the county in 1937. 


\section{Acknowledgements}

Soon after I finished writing the last chapter in this dissertation, I printed the manuscript in its entirety for the first time. That a large stack of papers (nearly three hundred at the time) had come to represent the last six years of my life and work was a bit revealing. As Dr. Lewis has said, completing a dissertation requires as much (if not more) perseverance than skill, and I heartily concur. The road to its defense has taken a variety of twists and turns, in both the personal and professional senses, and I come to the end of my journey a much wiser and thankful individual.

I have been blessed with the assistance of so many people that I fear that I may leave someone out. If you are one of these individuals, I beg your forgiveness. Nevertheless, I will attempt to extend my heartfelt thanks to the following:

To my committee, Dr. Ronald Lewis, director, and Dr. Elizabeth Fones-Wolf, Dr. Ken Fones-Wolf, and Dr. Joe Super; your encouragement and direction have been invaluable in completing this dissertation. I extend a special thank-you to Dr. Dwight Billings of the University of Kentucky. His early scholarship on the role of religion in Harlan County has been extremely helpful to me, and I cannot thank him enough for contributing to my research and writing as an outside reader;

To Dr. Briane Turley, who directed my studies in Appalachian and Mountain Religion and encouraged me to pursue this course of research. Briane, as both a friend and colleague, believed in the value of my "hunch."

To the archivists and staffs at the following libraries and collections; Southern Appalachian Archives at Berea College, Berea, Kentucky; The Dixon Pentecostal Research Center at Lee University, Cleveland, Tennessee; The Historical Collections and Labor Archives at the Paterno Library, Pennsylvania State University, State College, Pennsylvania; State Historical Society of Wisconsin. Madison, Wisconsin; University of Kentucky, Special Collections, Lexington, Kentucky; and the Appalachian Archives at South East Community College, Cumberland, Kentucky. A special thank you goes out to Theresa Osborne, at the Appalachian Archives, who acted as my unofficial research assistant on more than one occasion.

To Alessandro Portelli, who was so generous in sharing from his personal collection of oral histories. I can only hope that my contribution to the history of the miners of Harlan County and his own, personal quest to discover the answer to "Who really organized Harlan County?” is a worthy one;

A very special thank-you goes to Reverend Michael Szpack, the religious liaison for the AFL-CIO and an ordained Methodist minister with the Baltimore-Washington conference. Reverend Szpack researched the relationship between the Church of God and the labor movement in Kentucky, West Virginia, Virginia, and North Carolina during his seminary days. As he conducted research on labor unions in mine and mill towns in Southern Appalachia during the 1980s, Reverend Szpack was able to document a 
correlation between the growth of the Church of God (Cleveland, Tennessee) congregations and union locals in coal field communities in Kentucky and West Virginia, as well as mill towns in the Carolinas. Nevertheless, he was still intrigued with the role that that such a politically conservative church such as the Church of God may have played in Harlan County's mine wars. I became aware of Michael Spzack's work in Philip Grammich's book Local Baptists, Local Politics: Churches and Communities in the Uplands' South (The University of Tennessee Press, 1999) and contacted him. In a series of conversations with Reverend Szpack, he told about his visits to Harlan County and bombings at two Holiness-Pentecostal churches that supported the United Mine Workers union' efforts to organize the miners during the Depression. We were both intrigued by a possible correlation between the growth of churches such as the Church of God and the United Mine Workers Union in eastern Kentucky. Reverend Szpack's strong commitment to social activism, the United Methodist Church, and the AFL-CIO had hampered his ability to devote the time required to research the possible link between the Church of God, the miners, and the United Mine Workers Union. Finally, after a series of emails, phone conversations, and visits, Reverend Szpack decided to give his valuable collection of data and research papers to me to use in my research. I cannot thank him enough for his generosity and support and only hope that the results of my work is a source of satisfaction for a scholar and activist whom I hold in such high regard;

To the circle of friendship that has surrounded me during this journey. I have been blessed with a special group of friends, many of whom have traveled this road themselves. We have laughed and cried, through our studies, conference presentations, and the trials and tribulations that accompany the research and writing processes. This journey has been a special one, because of the special friendships that I made along the way. A special cheer goes to my friends and colleagues, Connie Rice, Rebecca Bailey, Paul Rakes, Shirley Stewart Burns, Diane Barnes, Jill Martin, and Paul Yandle.

To the families of Reverend B.H. Moses and Hamp Wooten. Getting to know so many members of the Moses and Wooten families has been a real blessing. As Elder Fugate said, "Everyone has a right to be heard." It is time that your fathers' sacrifices come to the forefront. Thank you for sharing your memories with me and supporting my work. I am especially appreciative to the Moses family for their prayerful support.

To my husband Robert, my parents, and our family, who have put up with numerous trips away from home for research and conferences, thousands of hours spent in the library and on the computer, frequent periods of distractions, a few forgotten birthdays, and more than one ruined dinner. Without your love and support, all of this work would be a series of meaningless exercises. I love you all more than you will ever know. 


\section{TABLE OF CONTENTS}

Map

Page

Introduction

vii

1

Harlan County, Kentucky: Fascination and Questions Linger

Origins of This Project

Purpose

Historiography

Presentation

1. Faith, Power, and Conflict: Wars of Position Within the Realms

Faith: Mountain Religion's Long Legacy of Resistance;

Mountain Religion Parts Company with Mainstream Protestantism;

The Rise of the Sects and Pentecostalism

Power Shifts Within the Realms:

Company Towns, Company Churches

Class Conflict Within the Church

The Miner's Church

2. Religion: Opiate or Tonic?

Power and Conflict: A Matter for Interpretation

Billings

Gramscii

The Appalachian Mountains; Home to Liberation Theology Before "It Was Cool"

A New Paradigm

3. Labor Unions and Religion: Unlikely Bedfellows with a Long History

The First Industrial Revolution

The Labor Forward Movement

The Rise of John L. Lewis, A Different Kind of Savior to the Working Class

The Harlan County Mine Wars: A Revolution Sanctified and Washed in the Blood

4. The Ascendancy of King Coal and the Fiefdoms of Benham and Lynch

Life and Work Before Industrialization

The Rise of the Coal Industry

A Judicious Mixture

Conversion: Miners Answer the Union's Call 
5. And the Walls Came Tumblin' Down

African American Migrants and Miners

Miners and Union Men

6. Revolution in the Coal Fields: Union Crusades in Bloody Harlan

The United Mine Workers of America

National Miners Union

Fall-out from the Battle of Evarts and the NMU

7. We Will Make You Fishers of Men: Preacher Organizers and the 184 UMWA

Reverend B.H. Moses

Reverend Marshall A. Musick

Reverend William Clontz

Reverend Matthew Hollars

Reverend Matthew Bunch

Hamp C. Wooten 


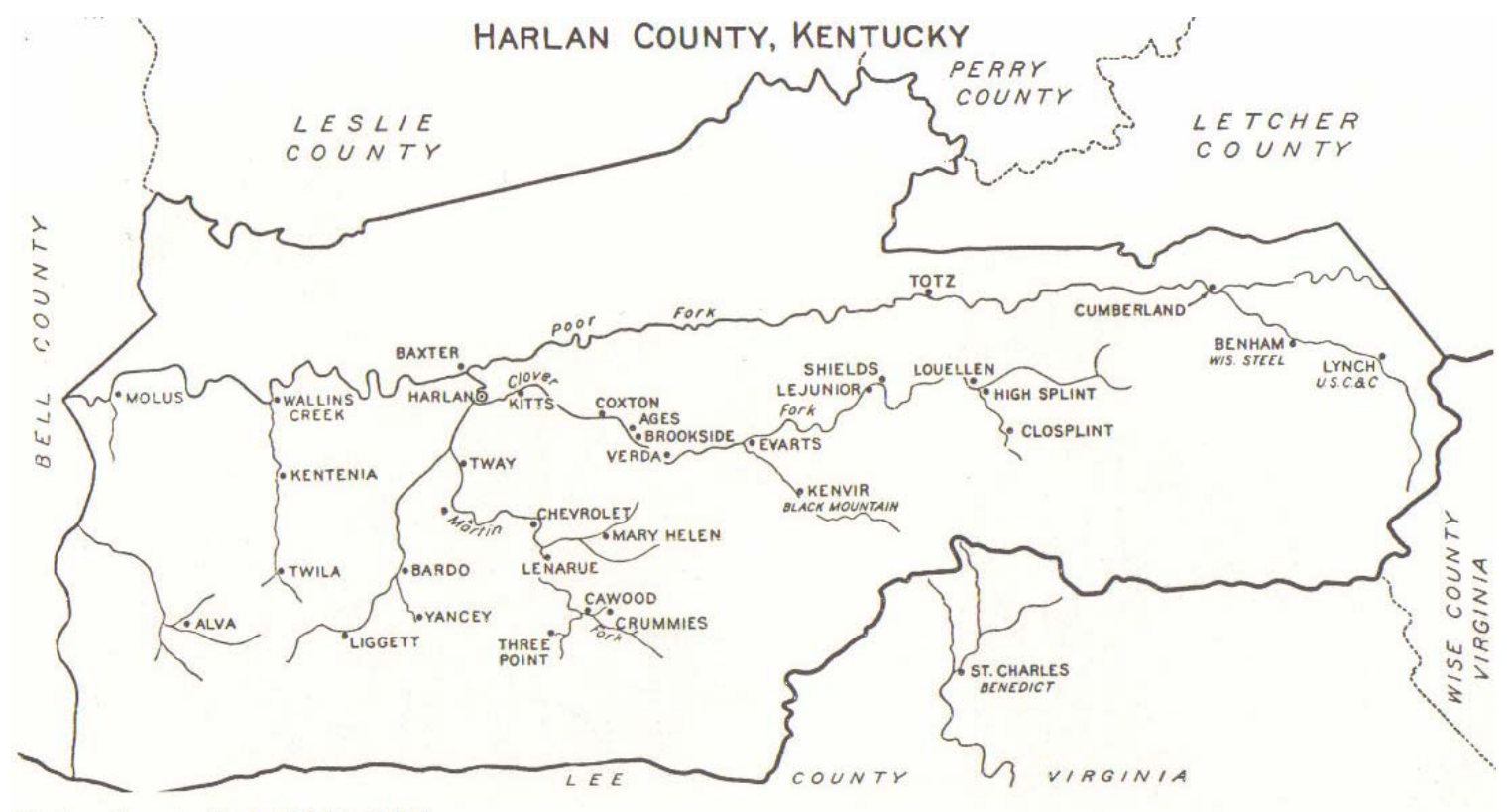

Harlan County Coal Field in 1937

Source: John W. Hevener, Which Side Are You On? The Harlan County Coal Miners, 19131-1939. Urbana and Chicago: University of Illinois Press, 2002. 


\section{INTRODUCTION}

"Leadership is incredibly important...Leadership exists only when individual vision joins with a community's respect. It's fleeting and it's rare... Communities without leaders are like gas stoves without a spark or match. They never generate any heat... The real leaders in a community are often overlooked... They are unnoticed... 1

In 1973, college student Bill Bishop traveled to Harlan County as part of a schoolsponsored trip. Before his departure, Bishop read novelist Theodore Dreiser’s book Harlan Miners Speak, a collection of interviews detailing the working and living conditions that eventually led to the Battle of Evarts, a bloody conflict between miners, operators, and the sheriff's department in May 4, 1931. According to Dreiser, the leadership behind the movement largely consisted of outsiders from the North, not local miners. Upon Bill Bishop’s arrival in Harlan County, the future journalist asked older miners about Dreiser’s book and the strike. To Bishop’s surprise, the older miners declared that they had never heard of Dreiser or any of the organizers mentioned in Harlan Miners Speak.

Two possible reasons may explain the miners’ responses to his questions: First, the Battle of Evarts occurred more than forty years before his visit. No doubt, the passage of time dimmed their memories of the conflict. Secondly, miners and their families suffered severe want during the strike and saw friends and relatives injured, killed, or imprisoned for their participation, events that many surely chose to forget. In spite of the validity of these reasons, Bishop believes that the real reason the old timers'

\footnotetext{
${ }^{1}$ Bill Bishop, “Leadership Can Only Exist When Vision Joins Respect,” The Kentucky Post: Online Edition, http://www.kypost.com/opinion/kguest092899.html, accessed 27 October 2004.
} 
could not remember Dreiser or the organizers is that the true leaders of the 1931 strike were local men such as William B. Jones. Miners like Jones were at the forefront of strikes throughout the decade even though history has given them scant recognition. While acknowledging the effect that time has upon memory, this writer concurs with Bishop for two reasons. First of all, the true leadership, especially in a sustained movement, is of the home grown, indigenous variety. Invariably, these local leaders are swept aside when outsiders arrive with the financial and human resources necessary to implement a successful organizational drive. ${ }^{2}$ Labor historians have typically compounded the problem and permanently removed the grassroots leadership from the public memory with their insistent focus upon national labor unions and the powerful personalities at the helm.

Early accounts of the mine wars place the inability of the United Mine Workers of America (hereafter UMWA) to establish a permanent foothold in the county, first at the feet of the powerful, well-heeled men of the Harlan County Coal Operators Association (hereafter HCCOA), and secondly at the worn work boots of miners who, when work was plentiful, saw little or no need for a union. The power of the HCCOA is not in question. Its members used their immense wealth and influence to build a million dollar war chest to fight the union and to maintain their iron-clad grip upon the county’s political, judicial, and legal systems. In doing so, the association built such an impenetrable fortress around the county that without the assistance of the international UMWA and the protection of the federal government, local unionists were unable to maintain union recognition.

Unfortunately, the international UMWA abandoned the Harlan miners, not once, but twice during the 1930s, first in 1931 and again in 1934. During the early spring of

\footnotetext{
${ }^{2}$ Bill Bishop, “Leadership Can Only Exist When Vision Joins Respect.”
} 
1931, wage cuts and irregular employment prompted the union to initiate an organizational campaign. In May, tensions between miners and operators culminated in the Battle of Evarts. Thereafter, the union refused to contribute strike relief, joined with county officials in a call for troops to quell strike-related violence, and abandoned its campaign to organize the miners. In the summer of 1933, the UMWA returned to the county after the passage of the National Industrial Recovery Act, Section 7 (a), which guaranteed employees the right to join a union of their choice and to bargain collectively. On October 27, 1933, the operators' association signed a union contract. In spite of the agreement, between October 27, 1933 and March 31, 1935 only half the county’s major mines considered themselves bound in any way to the union. Operators flexed their muscles and launched a counterattack that nearly expelled the union from the county by mid-1935 and sent international organizers packing. Union organizers shunned Harlan County until early 1937.

UMWA support for the Harlan miners might have evaporated, but the miners' desire for a union remained. In spite of the UMWA's lack of support, a small corps of local miners secretly drummed up support for the union, converting one man at a time. Most miners had signed a yellow dog contract in order to obtain employment in the mines, and they knew that if their membership were revealed to the company they would face immediate dismissal and eviction from company housing. As a result, card carrying union men worked side- by- side, completely unaware of their union brotherhood. Local union stalwarts kept the labor movement alive in this manner for years. Who were these men, and where did they obtain the resources to carry on their work, especially after the United Mine Workers of America turned its back on the Harlan miners? 
The county's miners persisted in their demand for change in the work place and within the community. Why? The answer to this question is connected with a force which radicals often regard as an opiate of the people and a bulwark in the defense of the status quo-- religion. The plain folk religion of the mountaineers, with its emphasis on the centrality of the Holy Spirit and literal interpretation of the Bible, empowered these miners to preach the gospel of Jesus Christ and Unionism, and God's Word sanctified their revolution. Equally important to the sustenance of the labor movement was the arsenal of resources located in the most unlikely places, the numerous tiny churches that dotted the valley floors and mountainsides of a county in which the Harlan County Coal Operators Association maintained a virtual "reign of terror.”3

For Harlan County miners, joining the United Mine Workers of America meant an end to their quiescence. They refused to remain voiceless in exchange for employment and housing. Joining the union also meant that they would face the disapproval of churches within the Protestant mainstream. Coal operators provided schools, hospitals, churches, Sunday schools, and social workers in order to create a community that fostered law and order, loyalty to the company, and a good work ethic. ${ }^{4}$ Typically, coal operators invited denominations such as the United Methodist, Episcopal, and the Roman Catholic Church, to send seminary-trained clergy to fill the pulpits of their churches. These congregations, whose pews were primarily occupied by company officials and members of the merchant class, set community standards for acceptable

\footnotetext{
${ }^{3}$ In 1935, the Denhardt Commission, a state investigatory commission, reported that "in Harlan County there exists a virtual reign of terror, financed in general by a group of coal mine operators in collusion with certain public officials; the victims of this reign of terror are the coal miners." Congressional Record, $74^{\text {th }}$ Cong., ${ }^{\text {st }}$ sess., 1935, vol. 79, 8987-8988.

${ }^{4}$ Ronald D. Eller, Miners, Millhands, and Mountaineers: Industrialization of the Appalachian South, 1880-1920 (Knoxville: The University of Tennessee Press, 1982), 192-193.
} 
behavior and religious values. This was especially true regarding the community's stance against labor unions. Since coal companies usually paid for the construction of the building, provided all of the necessary utilities, and paid the minister's salary, either in whole or in part, Harlan's company churches relied upon the financial support of the operators for their survival. ${ }^{5}$ Fearing dismissal, few ministers were willing to preach against the company, and their sermons reflected the needs of the operators. Thus, not surprisingly, company preachers told miners that unresolved problems were to be endured. Miners were encouraged to keep their eyes upon heaven where they would ultimately be rewarded. In addition, company preachers declared that unions and their organizers were the agents of Satan and his followers. Union organizers were declared outside agitators who were determined to destroy the important American ideals such as freedom of religion, patriotism, and capitalism. ${ }^{6}$

Labor historian David Corbin points out in his book The West Virginia Mine Wars that miners shunned company churches, because they were acutely aware that operators established them primarily as a means of social control, a point that was documented in a study of the Logan County, West Virginia coal field by theologian William John Bryant Livingston. As a theology student at the end of World War II, Logan traveled to Logan County to determine why the Presbyterian Church had failed so miserably at reproducing

\footnotetext{
${ }^{5}$ John Hevener, Which Side Are You On? The Harlan County Coal Miners, 1931-1939 (Urbana and Chicago: University of Illinois Press, 2002), 21. According to U.S. Census guidelines, only persons who were on official church payroll could list their occupation as minister or clergy. While the county seat and commercial towns listed several persons as ministers, most of the coal camps and villages rarely had anyone who could give their occupation as minister. Various primary sources provided this writer with the names of various ministers and their churches. When found in the census, these men typically listed blue collar jobs as their occupations. Most of them were coal miners. National Archives and Records Administration, 1930 Census, Kentucky, Microfilm Publication T626, Roll No. 748-749.

${ }^{6}$ David A. Corbin, Life, Work, and Rebellion in the Coal Fields: The Southern West Virginia Miners, 18801920 (Urbana and Chicago: University of Illinois Press, 1981), 150; John C. Hennen, The Americanization of West Virginia: Creating A Modern Industrial State, 1916-1925 (Lexington: The University of Kentucky Press, 1996), 100-101.
} 
itself in the state's coal towns. During his interviews with miners and clergymen, Livingston learned that miners shunned denominational churches in independent towns as well, because these churches typically strove to remain "neutral” during times of industrial strife. He concluded that hierarchical churches such as the Presbyterian Church had little chance of succeeding in a rural industrial county such as Logan. ${ }^{7}$

In Harlan County, only the model company towns of Benham and Lynch and the commercial centers of Evarts, Cumberland, Wallins, and Lloyal had denominational churches. Those in Benham and Lynch were company constructed and maintained. Like their peers in Logan County, West Virginia, Harlan County miners turned their backs on company churches. Instead, miners and their families usually attended small, non-denominational churches that were pastored by bi-vocational preachers. These churches were numerous and located alongside narrow, rugged mountain roads or isolated stretches of highway, purposely located outside the closely guarded limits of coal camps and towns. The pastors who presided over these pulpits preached a theology of their own design-- a working class theology that spoke to the spiritual and material issues that miners dealt with on a daily basis. ${ }^{8}$ The growth of nondenominational churches and sects paralleled that of the coal industry during the 1920s and 1930s, and by the end of the mine wars churches such as these could be found all over hills and mountains that surrounded the company towns and camps. These churches were usually shepherded by one of their own, a miner who, upon receiving the call from God, constructed a church where he preached on Sundays and mined coal the rest of the

\footnotetext{
${ }^{7}$ William John Bryant Livingston, “Coal Miners and Religion: A Study of Logan County” (Ph.D., dissertation, Union Theological Seminary, 1951), 225-233.

${ }^{8}$ Richard J. Callahan, "Working With Religion: Industrialization and Resistance in the Eastern Kentucky Coal Fields, 1910-1932” (Ph.D., dissertation, University of California-Santa Barbara, 2002), 132.
} 
week. The development of indigenous spiritual leaders who worked in the mines is significant, as noted by David Corbin shows. West Virginia miners rejected the ideological dogma of company churches by establishing their own. However, he insists that the influence that these churches and their miner preachers had on both the community and the labor movement should not be over-emphasized. ${ }^{9}$ Corbin is like many radicals who think that class must super-cede religion rather than incorporate religion into the culture of class. In doing so, David Corbin minimizes the role that these miner preachers and their churches played in the union movement. Just as society has relegated miners and their churches to the fringe, scholars have downplayed their importance in the labor movement. The story of the labor movement in Harlan County is more than the story of a well-financed power play between John L. Lewis and the Harlan County Coal Operators Association. The real story is one of a grass roots movement in which everyday people, their churches, and preachers, kept the union fires burning even after the Savior of the Union, John L. Lewis, abandoned them. Only when the federal government stepped in to provide "fire insurance" did the UMWA enter the fight, providing the men and money needed to end the wars in the union's favor. In the interim, a small group of miners furtively worked to recruit miners for the union. These miners, several of whom were preachers, worked in the shadows to recruit miners and waited for the day when it would be safe to declare their membership and hold meetings in the open without fear of retaliation. It is time these miner preachers and their working class congregations took center stage, where they belong, and that is the primary purpose of this study.

\footnotetext{
${ }^{9}$ Corbin, Life, Work, and Rebellion, 158-159
} 
Harlan miners understood that the union was their only earthly means to economic and political salvation, and miner preachers saw their involvement in the movement as a response to God's calling them, once again, into service. Their participation in the mine wars of the 1930s was not the first time that miner preachers were involved in the UMWA. Their union involvement was part of the UMWA tradition in eastern Kentucky. The first UMWA secretary in Harlan County (1918-19) was a preacher by the name of Frank Keller. The tradition continued into the Depression when three local preachers, B.H. Moses, Marshall A. Musick, William Clontz, led the drive to organize the county. Matthew Hollars, a Church of God (Cleveland) minister from nearby Jellico, Tennessee, and Presbyterian minister and District 17 international organizer, Matthew Bunch, volunteered to go to Harlan in 1936. These five men made up the hub of leadership in the ongoing struggle to organize the Harlan County miners from 1932 through 1939. Other miner preachers, their families and congregations, and local ministers whose names have been lost to history worked alongside them in the grassroots movement to establish the United Mine Workers Union in the county and obtain a contract with the Harlan County Coal Operators Association. The mandate behind their fight for social justice emanated from the Word of God.

If the entire story is to be told, an additional perspective is needed. Historians have documented the pivotal role that local clergy and their congregations played in the civil rights movement of the 1960s. The principal goal of this study is to fill in one of the missing chapters in Appalachia's history, the role of religion in the labor movement of the twentieth century. 
The origins of my interest in the intersection of the worlds of work, worship, and labor came about while researching the Labor Forward movement in West Virginia. I was especially intrigued with the strong religious rhetoric of Socialist workers and preachers as evidenced in letters to the editor and articles found in the Wheeling Majority, the socialist party's official newspaper in Wheeling and one of the most prominent socialist papers of its time. Until then, I had erroneously believed that the majority of the working class had little, if any, interest in religion.

It was during my research that I read Clifford Grammich’s book Local Baptists, Local Politics: Churches and Communities in the Middle and Uplands South, and found an intriguing piece of information concerning the role of Pentecostal Churches in local labor movements. In a chapter on "The Strengths of Adaptation for Labor: Organized Labor and Traditional Protestantism,” Grammich discusses the reversal of some Pentecostal churches in the coal fields of Central Appalachia during the Depression, a move in which the churches abandoned their anti-union teachings upon learning that most of their ministers had participated in organizing drives. Support for labor unions developed within the churches at the grassroots level because the government of the churches was (and still is), according to Grammich, "simple, individualistic, and highly adaptable to the community,” a condition that fostered such support. ${ }^{10}$

In 1977, labor historian Herbert Gutman called for scholars to take a more multifaceted approach to the study of the working class, especially as it pertained to the role that religion played in their everyday lives. ${ }^{11}$ Unfortunately, only a few heeded his

\footnotetext{
${ }^{10}$ Clifford Grammich, Jr., Local Baptists, Local Politics:Churches and Communities in the Middle and Uplands South (Knoxville: The University of Tennessee Press, 1999), 118.

${ }^{11}$ Herbert G. Gutman, Essays in American Working Class and Social History (New York: Vintage Books, 1977), 9.
} 
advice. Scholars were slow to turn away from their focus on institutions and powerful individuals, such as the United Mine Workers Union and John L. Lewis, and other national players in the American labor movement of the twentieth century. During the 1970s, sociologists and historians traveled to Appalachia, hoping to finally discover a cure for the region's endemic poverty. John Hevener was one of the New Labor historians to re-examine the mine wars. His research resulted in the 1978 publication of the book Which Side Are You On?: The Harlan County Miners, 1931-39, the most scholarly treatment of the struggle to end the infringement of miners' civil rights and the violence committed against them and their families. Since its initial publication, Hevener's book has been the point of origin for any study relating to the mine wars. He documented the role that various miner preachers played in the mine wars, but like most of his predecessors, his analysis focused upon the role of the federal government, the international UMWA, and John L. Lewis.

The emergence of social history had a powerful effect on religious history. As social historians focused their energy upon re-writing history from the bottom up, so did their counterparts in the field of religious history. In the last two decades, religious historians have been focusing upon groups outside the Protestant Mainstream, groups long considered to be outsiders. Thus, instead of studying Congregationalists and Lutherans scholars are recording previously untold stories about evangelicals, Roman Catholics, Mormons, and Pentecostals.

Therefore, the time is right to reexamine the role of the independent churches in the communities of Harlan County. For the working class, this means a visit to the churches on the fringe and a redefinition of "fringe," from an area constructed by the 
people to one constructed by the power elite. In spite of the important contributions of labor historians such as Hevener, a gap in the scholarship remains. First, conflicts between miners and operators have been treated primarily as a series of episodes of laborrelated violence. This was the case in Lon Savage’s 1985 book on the 1920-1921 West Virginia mine war, Thunder in the Mountains: The West Virginia Mine War, 1920-21. ${ }^{12}$ Secondly, organizations such as the National Miners Union, the United Mine Workers of America, and the Harlan County Coal Operators Association commanded the attention of Hevener, Corbin, and Savage. The violence that erupted in Harlan, and the importance of these organizations are not in dispute, but insufficient attention has been given to people at the grass roots who comprised the backbone of the ongoing movement to organize the county: coal miners, their families, and the churches who kept the fires burning when the United Mine Workers backed away from the fight. Anyone willing to take up the cross of the Harlan miners did so at great risk. No one was safe. The list of fatalities and injuries included the young and old, women and children, and the Sheriff's own kin. Ministers were not excluded. "Men of the cloth” knew that their churches would not be safe havens during the "reign of terror," especially if they were also miners and good union men. Coal operators employed all the tools at their disposal to keep out the union and safeguard their profits, but in the end this did not thwart the formation of class-consciousness and the miners' desire for a union.

If we are to determine who really organized Harlan County, we must take a good, long look at the local people and their religion. A grass roots perspective of the mine wars requires a "front porch" visit with miners, their kin and neighbors, and preachers to

\footnotetext{
${ }^{12}$ Lon Savage, Thunder in the Mountains: The West Virginia Mine War, 1920-1921. Pittsburgh: University of Pittsburgh Press, 1990.
} 
determine the extent that their faith, one of the defining elements in the culture of the Appalachian South, influenced their participation in the labor movement. An analysis at the grass roots level, within local working class communities, churches, and among individuals is especially needed. Such an analysis calls for a scrutiny of the religious discourse and practices of coal miners and their families in the mines, at home, and at church.

Believers who found themselves in the midst of the industrial transition that took place in Harlan County turned to their existing religious idioms and practices to negotiate their way through unfamiliar terrain. Unfortunately, for historians, during the sixty years since the mine wars, nearly all of the key participants are deceased, making a true "front porch visit" with them impossible. Therefore, one must turn to local newspapers, church records, newsletters, and magazines, census records, diaries, and oral histories to fill the void. This type of research and analysis will create a new picture of Harlan County as part of a region that is active and engaged, rather than passive and acquiescent. ${ }^{13}$

This will also repaint the long-cherished portrait of the Appalachian religion. As this study will demonstrate, Appalachian religion is not the religion of, in William Goodell Frost’s phrase, “our contemporary ancestors.” It is not a religion for those determined to remain in the past, stubbornly resistant to change and progress, a theology containing all of the tenets necessary for the creation and maintenance of a culture of acquiescence, poverty, and exploitation. ${ }^{14}$ Many of the Harlan miners and their miner preachers practiced a religion that may have been regarded as old-fashioned and strange,

\footnotetext{
${ }^{13}$ Richard Callahan, “Working With Religion,” 60-66.

${ }^{14}$ William Goodell Frost, "Our Contemporary Ancestors in the Southern Mountains,” Atlantic Monthly, 83 (March 1899): 311, reprinted in Appalachian Images in Folk and Popular Culture, $2^{\text {nd }}$ ed., W.K. McNeil, ed. (Knoxville: University of Tennessee Press, 1995), 91-92.
} 
but it contained all of the resources necessary to survive the campaigns of terror, and to keep the hope for union representation alive against all odds.

Most of Harlan County's numerous churches are independent and nondenominational and therefore had no need to maintain records for a central governing body to oversee or archive. Few saw any need to keep any historical record at all. Instead, theirs is an oral religious tradition, positing most of the primary sources of information in the less explored arenas of oral history, oral tradition, and material culture. As Deborah Vansaw McCauley and other scholars who have recently begun to examine the intersection of the religious and socioeconomic spheres of Appalachia have discovered, worship--the preaching, singing, and praying, along with the trade marks of Pentecostalism such as messages in tongues and interpretations, visions and dreams-- is the primary source for mountain religious life. ${ }^{15}$

Those who are engaged in the study of contemporary issues can visit mountain churches and experience the worship services and glean valuable information from members of the congregations. In contrast to this, historians depend upon records and artifacts to reconstruct the scenes of events of long ago. The passage of nearly seventy years since the mine wars, death of the principal participants, and the paucity of church records, make recreating the story difficult, but not impossible. Fortunately, in the 1980s, college students and scholars began gathering oral histories, recording the stories of actual participants of the Harlan mine wars as well as the observations of their children, neighbors, and kin. Scholars continue to gather family stories that have been handed down, from parents, to their children, and their grandchildren. Information regarding the

\footnotetext{
${ }^{15}$ Deborah Vansau McCauley, Appalachian Mountain Religion: A History (Urbana and Chicago: University of Illinois Press, 1995), 20.
} 
religious beliefs and practices of non-denominational, independent mountain churches are usually limited to oral histories and, very rarely, old family letters and diaries. Luckily, several of the holiness-Pentecostal churches located in Harlan County are part of a denominational body. Churches such as the Church of God (Cleveland, Tennessee), the Assembly of God, and those belonging to the Southern Baptist Convention, are found throughout Appalachia. As a result, it is possible to find additional sources of information, such as church newsletters, magazines, local church records, assembly and convention minutes, correspondence, photographs, diaries, and personal papers of ministers. Until recently, these churches were reluctant to grant access to outside researchers. Within the last five years, many denominations realize the importance of recording their histories and have begun to ask their members to donate any old documents that they might have to their church archives. At the same time, church historians and archivists have begun to work with scholars, even those without direct ties to their church, who are genuinely interested in contributing to the creation of their historical mural. The Church of God (Cleveland, Tennessee) Archives, located at Lee University, in Cleveland, have been diligently working to acquire such sources and have been very important to this work. Even those who attend the more common nondenominational, independent churches see the need to create a written record of their church's history as a witness to God's faithfulness for succeeding generations. As a result, people are becoming more willing to talk with scholars such as myself. Everyone has a story to tell and a right to be heard.

The study is divided into six chapters. A discussion of the history of mountain religion and its long tradition of resistance is presented in Chapter 1, "Faith, Power, and 
Conflict.” This chapter also includes a description of the intricate relationship between Mountain Religion and American Protestantism and the roles that their churches play in the coal communities of Appalachia. At the heart of this chapter lies a discussion of Holiness-Pentecostal movement and the rise of the sects in Appalachia since HolinessPentecostal churches such as the Church of God (Cleveland, Tennessee) played an important part in the rise of the union movement in Central Appalachia. As the county transformed from one based solely upon agriculture to an agricultural-industrial economy where coal became king, old power relationships based upon family and honor gave way to new relationships based upon wealth.

Chapter 2, "Power and Conflict: Quiescence or Rebellion”? examines the power relationships between company churches, their middle class congregations, and the more numerous non-denominational churches and sects that were the religious centers of the working class are explored. The dual function of religion and the reasons behind the sides taken by the various churches are interpreted through models proposed by sociologists Antonio Gamscii and Dwight Billings. The latter part of this chapter places the home of liberation theology in Appalachia, where, as theologian Reinhold Niebuhr hoped, miners lived according to their own brand of working-class theology, and used it to sanctify their revolution. Thus, the miners and preachers were practicing Liberation Theology long before Gustavo Gutierrez and Richard Schall proclaimed it to be Latin America’s saving grace.

Chapter 3 addresses the relationship between labor unions and organized religion. As religious historians are now pointing out, unions and religion also have a common history of resistance. Religion has sanctified the rebellion of workers since the First 
Industrial Revolution. While the rise of the sects, particularly the Church of God, is fully detailed in the first chapter, the linear progression of the association between organized labor and religion is described in Chapter 3, "Labor Unions and Religion: Unlikely Bedfellows With a Long History.” Although organized labor and religion may appear to be strange "bedfellows," they have shared the same bed for quite some time. In their struggle to establish a labor union in Harlan, the preacher organizers and their followers participated in the Christian Social movement, the working class sister to her more widely known, middle class sister, the Social Gospel Movement.

Chapter 4 chronicles the rise of the coal industry in Harlan County in the creation of the crown jewels of company towns, Benham and Lynch. Determined to thwart any attempts to unionize their operations, International Harvester and United States Steel carefully orchestrated the planning and construction of Benham and Lynch. Their antiunion arsenal included a judicious mixture of employees, fully equipped, state of the art schools, beautiful churches, and well-armed police forces. Bringing the union to the miners of International Harvester and U.S. Coal and Coke was difficult, but not impossible, especially with the help of miner preachers and their churches.

Eventually, African American migrants from the Deep South and surrounding states made up more than half of the work force at Lynch. The story of their migration, their adjustment to life and work in Lynch, and their conversion to unionism is contained in Chapter 5, “And the Walls Came Tumblin’ Down.”

Chapter 6, "Revolution in the Coal Fields," chronicles efforts to organize the miners before the passage of the National Recovery Act. The UMWA first attempted to organize the county’s miners in 1907, but the union failed to establish a permanent 
presence in the county until 1937. The failure of the National Miners Union, the fall-out from the Battle of Evarts, and the Red Scare is the central concern of this chapter. Of special importance are the lessons learned by miners, the "better people of Harlan," and district and international leaders of the United Mine Workers of America.

As Elder Fugate told Appalachian scholar Loyal Jones, “Everyone is entitled to be heard.”16 The stories of the miner preachers and members of their families and congregations are told in chapter 7, “I Will Make You Fishers of Men: Preacher Organizers and the UMWA.” The international union decided to use local men as organizers in 1934, because, as William Turnblazer told John L. Lewis, it was nearly impossible for an outsider to penetrate the county for two reasons. First, traveling unfamiliar mountainous roads was perilous, considering the condition of the roads. Second, and more importantly, the sheer number of company-owned deputies patrolling the county's roads increased the likelihood that an organizer, once spotted, would never be seen again. The union first hired local miner preachers such as B.H. Moses to work as organizers in 1934. When George Titler arrived in Harlan County in 1937, he moved his preacher organizers to center stage, part of his strategy to thwart operators' determination to paint the organizing drive "red." In spite of the international's decision to use miner preachers as organizers and leaders in the drives, these men and their churches had already made the commitment much earlier and assumed responsibility for keeping the fires of unionism stoked when the UMWA abandoned the county. The passage of New Deal legislation, such as the Wagner Act, and congressional investigations by the LaFollette committee, were the fire (and life) insurance policies that the union and its

\footnotetext{
${ }^{16}$ Loyal Jones, Faith and Meaning in the Southern Uplands (Urbana and Chicago: University of Illinois Press, 1999), 11.
} 
leaders, both indigenous and those from districts across the nation's coal regions, needed to ensure that contracts negotiated by the United Mine Workers of America would be honored. However, if it had not been for commitment of these men, the union would have been forced to start from scratch during the 1937 drive.

The miner preachers and their churches return to center stage in the conclusion. As this dissertation illustrates, the real story behind the Harlan County mine wars is one of a grass roots movement in which everyday people, their churches, and preachers, did not lose hope. In spite of overwhelming operator opposition, the miners of Harlan County kept the union fires burning, until the federal government stepped in to provide "fire insurance" in the form of New Deal legislation, the La Follette Senate hearings, and legal action instituted by the Justice Department. In the interim, the United Mine Workers union regularly entered and exited the field when it was expedient. The real work behind the labor movement was one of the grassroots variety. International organizers, including George Titler, provided the window dressing for the final, victorious act. Local men were at the forefront of organizing drives from the beginning. A cadre of miner preachers led the way, preaching a working class theology that promoted trade unionism and the rights of the working man. 


\section{CHAPTER 1}

\section{FAITH, POWER, AND CONFLICT: WARS OF POSITION WITHIN THE REALMS}

The stories of Harlan County's preacher organizers, their families, and congregations provide one of the many missing chapters in Appalachia history. That their stories are missing from the historical record is not surprising when one considers mountain religion's place on the periphery of American society. Deborah McCauley sums it up best when she says that "mountain religion and mountain preachers suffer the fate of being portrayed either as drab, oppressive, narrow purveyors of doctrinal darkness or as emotional exotics left over from the worst excesses of the Great Revival." ${ }^{17}$ McCauley was most likely referring to present day perceptions of mountain religion and preachers, but these perceptions have existed for more than a century. Local color writers, such as Will Wallace Harney, began visiting the region immediately after the Civil War when the North was "discovering” the South. Like the work of other color writers, his stories, sketches, and poems were published in popular serials such as Lippincott's magazine. Harney visited the mountains of southeastern Kentucky in 1869 where he found a place abounding in "geological and botanical curiosities." ${ }^{18}$ His journey was chronicled in an article pushed in the magazine in 1873. In it, Harney described the people as having an anatomical frame "characterized by marked peculiarities" and believing that "Christ was God in the flesh, with other old doctrines now rapidly becoming heretical in the enlightened churches of the east." ${ }^{19}$

\footnotetext{
${ }^{17}$ Deborah Vansau McCauley, Appalachian Mountain Religion: A History (Urbana and Chicago: University of Illinois Press, 1995), 17.

${ }^{18}$ Will Wallace Harney, “A Strange Land and a Peculiar People,' in Appalachian Images in Folk and Popular Culture, $2^{\text {nd }}$ ed. Ed. W.K. McNeill (Knoxville: The University of Tennessee Press, 1995), 45.

${ }^{19}$ Harney, "A Strange Land and a Peculiar People," 45, 49.
} 
The mountains that fascinated many of their visitors and scared others shaped mountain culture and religion. Religious historian Catherine Albanese eloquently defines the religiosity of these early settlers and their descendents as a regional religion. According to Albanese, their religion was "born of natural geography, of past and present human history, and the interaction of the two." ${ }^{20}$ The reality of the land, its rugged terrain that was nearly impassable in many places, and climatic conditions that spawned both a diversity of flora and fauna and torrential downpours made settlement and early economic development difficult but not impossible. This reality shaped everything in the region's culture, from its houses and dietary preferences, to its religion and dialect.

The earliest visitors to the mountains were Cherokee hunting parties and Spanish explorers. The first to settle were the families of Revolutionary War soldiers who had received the land as bounty for services. The Scot-Irish, known for their piety, along with English and Germans from the Valley of Pennsylvania began moving south, into the Valley of Virginia as the eighteenth century came to a close. Virginia Baptists, fleeing from persecution for refusing to tithe to the Anglican Church, and African-Americans, both slave and free, found new homes in the mountains and valleys of Appalachia. The abundance of cheap, fertile land, abundant water for crops and livestock, wild game initially drew them to the mountains.

At the same time, settlers found that adapting to life in the region was more difficult than most had predicted. The rugged terrain, with its scattered, small patches of tillable land, narrow valleys, steep mountain sides, and the dry creek beds, old Indian trails, and the paths of deer that passed for roads made settlement scattered. Thus, the people were forced into egalitarianism and self-reliance to survive. At the same time,

\footnotetext{
${ }^{20}$ Catherine L. Albanese, Religions and Religion (Belmont, California: Wadsworth Publishing, 1981), 8-9.
} 
survival meant mutual dependence, a necessity that gave mountaineers a reputation for hospitality, towards strangers and kinfolk alike. Living in such a harsh climate, it is not surprising that mountaineers learned to "make do" with what they had.

The rugged terrain and lack of traversable roads led writer and author Emma Bell Miles and a seemingly endless succession of visitors to Appalachia at the turn of the twentieth century to bemoan the lack of community in the mountains. ${ }^{21}$ Mountain communities did not mirror those in more established areas, especially those north of the Mason Dixon line, but they did exist, albeit in a much simpler form. Family life revolved around the backbone of the mountain economy, the family farm. Primarily subsistence farmers, entire families toiled, day in and day out, to eke out a living. As settlements grew, the early pioneers pooled their resources and worked together to build churches and schools. In doing so, they established a more informal network of communication and social activities than those found in larger communities. Thus, geographical constrictions combined with nature's clock and calendar to determine school and church attendance.

In spite of these restrictions, the church was the center of any community. Mountain churches were small in size but numerous and scattered throughout the mountains. Circuit riding preachers passed through the communities on a scheduled, but sometimes irregular, basis, filled their pulpits, usually preaching to a standing room only crowd. When the circuit rider came, it was an important occasion for members of a scattered community. Hence, people gathered for miles around to attend worship services, weddings, funerals and memorial services, and to visit friends and neighbors

\footnotetext{
${ }^{21}$ Emma Bell Miles, Spirit of the Mountains (1905; reprint, Knoxville: The University of Tennessee Press, 1975), 71.
} 
rarely seen. It is not difficult to understand why Methodist Bishop Francis Asbury, a frequent visitor to the mountains during the latter part of the eighteenth century, remarked that it was harder for the people to gain religion here because of the harsh realities and distractions of frontier life. Attending church was difficult but not impossible. The rugged terrain shaped mountain religion but did not determine its final course. ${ }^{22}$

Mountain religion is a series of church traditions and religious movements, shaped by the land, its people, their history, and culture. The traditions are tied together with the same historical roots and are characterized by five elements: an independent church; emotionalism; the primacy of the Bible; the centrality of the Holy Spirit; and an non-professional clergy. Typically, churches that fall under the umbrella of mountain religion are independent, non-denominational churches, the most common form of religious organization in the region, especially in Central Appalachia. These churches are either independent Baptist or Holiness in doctrine and practice or are rural mountain churches belonging to the Church of God (Cleveland, Tennessee.) They practice the oldtime religion, with its foremost emphasis on piety. Mountain religion is centered on experiential religion or the religious experience whereby man is converted (reconciled to God) by grace instead of works or affiliation with any church. Thus, the conversion experience is an emotional, Holy Spirit-conceived experience, and not one necessarily initiated by man and the production of rational thinking. Furthermore, adherents to mountain religion believe that all men are saved by grace, not by works. All members are

\footnotetext{
${ }^{22}$ For a through discussion of industrial community life in Appalachia, see Ronald D. Eller's Miners, Millhands, and Mountaineers: Industrialization of the Appalachian South, 1880-1930 (University of Kentucky Press, 1982), 182-198.
} 
urged to follow Christ's example, and to love and serve one another in humility as the Holy Spirit directs. ${ }^{23}$

Since church members believe that the Holy Spirit is the guiding source for both individual believers and the church body, the governing of the local church tends to be of a very democratic nature in several areas. First of all, the Holy Spirit affects the power relationships within the church, especially in relation to the role of pastors. In mountain churches, the preacher is not in a separate class from his congregation. Instead, the Holy acts as a leveler between the laity and a pastor. Mountain preachers are only in a position of authority because of their calling, not their level of education. Because of this, they are rarely seminary-trained, and most possess only a modicum of formal education. In addition, the Holy Spirit calls individuals within the church to serve in various roles, regardless of gender, age, or education. This creates a priesthood of believers where preachers are equal to the members of their congregation, women are equal to men, and children are equal to adults, and all work together to further the kingdom of God on earth. The importance of the priesthood of believers is reflected in the way that church members and pastors speak to one another. Typically, both pastors and laity are referred to as 'brothers” and "sisters.” What Emma Bell Miles related about Brother Absalom and other mountain preachers of her era is still true today. The title “Reverend” infers that pastors are "a class set apart.” Promoting such a hierarchy in the church is strongly rejected in mountain culture. Instead, in the mountain church, the preacher works as a manager and encourages all members of his congregation to participate as fully as possible according to their spiritual gifts. ${ }^{24}$

\footnotetext{
${ }^{23}$ McCauley, Appalachian Mountain Religion, 2-6, 58-64

${ }^{24}$ McCauley, Appalachian Mountain Religion, 103; Miles, Spirit of the Mountains, 121.
} 
This tradition of egalitarianism is embodied in the worship style of mountain churches, especially among independent Holiness groups where the heritage of camp meeting religion is the strongest. Churches with such a worship style practice free church polity, one of the most important features of mountain religion and another tradition that sets it apart from American Protestantism. In free church polity, the focus is on submitting the mind and heart in obedience to God's will, not on ecclesiology or doctrine, and authority rests upon the leading of God through the Holy Spirit within the body of believers, not in ecclesiastical or political structures. These churches claim to be governed by the Holy Spirit, the only One who knows the mind of Christ and the will of God. In such a setting, decision-making is a local, democratic process in which all members participate freely. ${ }^{25}$

It is in the area of free church polity that most strongly disputes the fatalistic nature of the mountaineer's religion. McCauley’s primary thesis points to religion’s ability to empower, especially when it comes decision-making. According to McCauley, Appalachia mountain churches had clearly separated themselves from the Protestant mainstream (commonly referred to as American Protestantism), of its own volition, by 1825-27. It was at this time that Protestant churches becoming more denominational. Denominationalism, "the phenomenon of national church institutions based on voluntaryism and organized around a national purpose and identity,” had become the hallmark of American Protestantism well before the Civil War.

In 1830, mountain churches were at a crossroads. In what constituted a "seismic shift," ${ }^{26}$ adherents to mountain religion chose to retain their traditional religious beliefs,

\footnotetext{
${ }^{25}$ McCauley, Appalachian Mountain Religion, 92-93, 109.

${ }^{26}$ McCauley, Appalachian Mountain Religion, 13.
} 
beliefs that were rooted in Calvinism, with its emphasis on grace and the Holy Spirit. In doing so, they continued to travel down the previously crowded road of American religious tradition while mainstream churches took a new road, one that was built upon free will and rationalism. This led to the creation of two very different sets of religious values, with opposing world views. Churches within the Protestant Mainstream embraced the Social Gospel, with its emphasis on human initiative with God's cooperation, and social change through good works. In contrast to this, mountain churches maintained that society had little hope, if any, to realize true reform. For these believers, they deemed that reform efforts that failed to recognize the sinful nature of man and his need for salvation were doomed to fail. Such a distinct religious ethos, according to Deborah McCauley, permeates Appalachian culture that goes "well beyond the doors of the mountain church house." ${ }^{27}$ The strength of the religion culture, its communities, and its influence on the community, are important considerations in this study. The multitudes of believers who attend the numerous mountain churches of Appalachia uphold the tenets of old-time religion such as the need for a God-initiated conversion experience, the moral authority of the Bible and the centrality of the Holy Spirit. Since these beliefs shape the believer's world view and decisions made well beyond the confines of the walls of the church, mountain religion, argues McCauley, functions as the "most important and prominent stabilizing force in the socio-cultural life of the region. ${ }^{28}$ At the same time, it was inevitable that these opposing worldviews would lead to conflict within the greater religious community and the community as a whole. In time, these opposing views would serve the interests of capitalists determined

${ }^{27}$ McCauley, Appalachian Mountain Religion, 2, 8

${ }^{27}$ McCauley, Appalachian Mountain Religion, 2, 8

${ }^{28}$ McCauley, Appalachian Mountain Religion, 2, 8. 
to build a new socioeconomic order based upon wage labor and coal, and place operators and miners on a collision course.

By the 1850s Appalachian Methodism had undergone a great transformation as Methodists and Southern Baptists replaced the centrality of the religious experience with the institutionalism of denominationalism. Like the Southern Baptists, Methodism had become part of the "colonizing forces” as industrialists typically established Methodist churches in their company towns, a move that served the spiritual and social needs of owners and managers better than their workers. This did not go unnoticed. The Methodist Church became the church of the industrialists just as it had been the church of choice for Southern slave owners before the Civil War. ${ }^{29}$

As mountain religion maintained the traditions of old time American Protestantism, its adherents developed a religious culture whose values were in direct contrast to much of American Protestantism. This, along with the growth of education across the nation, set the stage for a campaign to "liberate" mountaineers from a backward religion, a religion that was based on ignorance, and superstition. Soon after, middle class churches from within the Protestant mainstream began sending missionaries and teachers into the mountains, establishing churches and schools to save the people from themselves. The region's inhabitants welcomed the schools, hospitals, and services that they provided, because they were few and far between in the mountains. However, as Loyal Jones points out in Faith and Meaning in the Southern Uplands, conflicts arose in the religious sphere since the workers knew little about the cultural background of those whom they came to save. In addition, they failed to understand, accept, or even tolerate mountain religion, especially since mountain Christians continued to adhere to

\footnotetext{
${ }^{29}$ McCauley, Appalachian Mountain Religion, 238-241.
} 
Calvinism and saw little hope for improvement in the "human condition.” Ultimately, mission workers rejected the religious culture of the mountaineers, defined them as "unchurched," and declared that the religion practiced by mountaineers had reduced them to a state of "moral and religious degradation. Clearly, the mountaineers and these workers did not "find comfort under the same theological blanket.”30

Mountain religion successfully resisted denominationalism and the liberalism of modern evangelical theology, and therefore posed a serious threat to the maintenance of the status quo. Mountain religion had tremendous appeal and influence in the working class, a fact that was not lost upon the leadership within the Protestant mainstream. Negating the power and influence of mountain religion could only be accomplished by either ignoring or dismissing its broad authority, or by generating stereotypes and prejudices that would demean these churches and their members, an act that would greatly diminish their potential influence outside the walls of church buildings. Such a goal ultimately led to the creation of the stereotypical portrayal of the members of mountain churches as fatalists, stubbornly resistant to any type of change in their religion, work, or community. When the labor movement came to the coalfields, the stereotype broadened as miners saw "the light" and began participating in organizing drives with a definite religious fervor. In turn, coal operators and their supporters labeled these miners in one of two ways. They were either deemed radicals who were a dangerous threat to the common good or members of strange, religious sects who were too ignorant to steer the course of their lives. McCauley states that such stereotypical images emerged by way of American Protestantism and were really issues of power. These images broached the

\footnotetext{
${ }^{30}$ McCauley, Appalachian Mountain Religion, 18 -19; Loyal Jones, Faith and Meaning, 3-4.
} 
boundary between the religious and socioeconomic spheres, and defined mountaineers as obstacles to progress. $^{31}$

During the 1870s and 1880s, speculators flooded the region, purchasing mineral leases for as little as $\$ 1$ an acre. Mineral leases looked like gifts from heaven to poor, illiterate farmers struggling to survive in an economy that was increasing its reliance upon cash. Land, timber, and mineral rights passed out of the hands of mountain families. Men, who had lived by nature's clock, eagerly looked forward to the cash wages that working in the timber and coal industry could bring. Many discovered that depending upon "public work" came at a great price, especially for those living and working in coal company towns. Adjusting to industrial organization and the feudal living conditions of the company town system proved difficult for most miners. Many miners turned to their faith for comfort, strength, and direction, but this did not mean that they turned to mission workers or local churches. ${ }^{32}$

In assessing the impact of industrialization in areas that were formerly located on the socio-economic fringes of American society, southern historian C. Vann Woodward stated that "the profit motive and missionary motive" walked "hand-in-hand" in the development of "backward people.” Missionaries and capitalists certainly assisted in one another's work, but the relationship was never equal. In doing so, even those with the best of intentions served the interests of capitalists and the growing middle class whose economic livelihoods dependent upon the continued vibrancy of the coal industry, a fact that rarely escaped the notice of members of the coal field community. ${ }^{33}$

\footnotetext{
${ }^{31}$ McCauley, Appalachian Mountain Religion, 28-29.

32 Eller, Miners, 45-54, 175.

33 Eller, Miners, 42, 45.
} 
Coal operators were "cheerful givers" when it came to financing churches associated with American Protestantism. They frequently provided land and buildings for churches in their camps, and more often than not, supplemented or completely paid their clergy's salaries. The number of coal field churches connected to the Protestant mainstream grew during the second, industrial period, but gained few members among the working class. With their socioeconomic interests and theology on opposite sides of the fence, the distance between miners and "better people of the community" expanded, flowing through the doors of the church and onto the street, conditions that served a death knell to Appalachia's, long-honored tradition of egalitarianism.

Shortly after the Great War ended, Paul Bunyon Shelton received his Bachelor of Divinity degree from the Chandler School of Theology at Emory University. For his thesis, Shelton studied "the social life” of the Tug River Coalfields of West Virginia. His observations mirror those voiced by the majority of clergymen from within the Protestant mainstream in the post-war era. While Shelton points out the failings of the Methodist Episcopal Church in regard to its ministry to coal miners, both native white, black, and foreign born, his remarks only reinforced the "otherness" of coal miners and their families. Shelton divided the population into two main groups, the non-mining group, composed of native whites primarily engaged in agriculture and the mining community, which he subdivided into three, smaller classes. The mining community was composed of "American white labor, Negro labor, and foreign labor." Most interesting is the theologian's divisions between American miners and the clergy's precarious position in the community. ${ }^{34}$

\footnotetext{
${ }^{34}$ Floyd Bunyan Shelton, “An Investigation of the Social Life of a West Virginia Coal Mining Field” (Bachelor's thesis, Chandler School of Theology, Emory University, September 1920), 10-20.
} 
Sheldon divided the mining community into two groups: those who "furnished the initiative" and those who were "mere followers." As to be expected, the mine superintendent, company store manager, his “corps of clerks,” the bookkeeping staff, and the camp doctor were among the group who "furnished the initiative." Ministers, however, were also placed among this group “only because he has to be placed somewhere." Shelton claimed that it was hard to define a "servant of all the community" who was also a member of a particular part of it. Nevertheless, he considered the clergy and their families to be among the "best people" in the community, and expected to take an active part in the town's affairs. The clergyman's precarious status was also tied to his relationship with the coal company. ${ }^{35}$

According to the Scriptures, the clergy work under ecclesiastic authority. However, since the company owned the church building and parsonage and paid part, if not all, of his salary, few coal field pastors could "deny that the fruition of their labor" depended upon the good will of company officials who frequently composed the majority of his board. As a result, company pastors had to be men of great tact and capable of serving the needs of both the company and its miners. If he was unpopular with the people, they either opposed his work or stopped attending his church. More often than not, miners and their families chose the latter. Most pastors assigned to coal camp churches were young, seminary trained, and from the middle class with little, if any knowledge of the characteristics and problems of the coalfields. As a result, most pastors had difficulty relating to the blue-collared portion of their flock. Worse yet, many pastors went to the coalfields already antagonistic to many of its social norms and activities and had nothing better to substitute in their place. Consequently, few company pastors

${ }^{35}$ Shelton, “An Investigation,” 10-20. 
tailored their sermons or ministries to the special needs of the miners and distanced themselves and their churches from his conflicts with the operators. Thus, as Shelton and other theologians from the period pointed out, it should not have been a surprise when the working class turned its back on the churches that resided on America's main streets in favor for those located on the geographic and social fringe. This was especially true of white miners. Native whites were religious conservatives and prejudiced against all faiths except their own, the majority being Baptist. Shelton found that native whites were "less affected by the new 'isms' in religion than the miners. This only gave them a slight edge over miners drawn to such "isms," because, like his contemporaries, Shelton believed that Baptist preachers, especially those belonging to ultra-conservative sub groups such as the old Hard Shell or Primitive Baptists, were "grossly ignorant,” fatalistic, and had little use for pastoral education. ${ }^{36}$ What was particularly damning to the author was their immorality.

The miners' apparent otherness was compounded by their perceived lack of morality. Even native whites who resided outside the mining community failed to meet Shelton's criterion for a well-developed society, a group whose "ethical standards that would hardly pass in a more highly developed society.” In order to illustrate his point, Shelton linked mountain people to the members of the Hatfield and McCoy families, made famous by their turn of the century feud. The theologian reminded his committee that Devil Anse Hatfield, who was still living at the time of the study, was a "respectable member of his people...in spite of the fact that he killed thirty-two persons. ${ }^{\text {}}{ }^{37}$ Miners, on the other hand, were, on the whole, "a restless, roving people” who moved constantly,

\footnotetext{
${ }^{36}$ Shelton, “An Investigation,” 10-20.

${ }^{37}$ Shelton, "An Investigation," 12-13.
} 
whether from one house to another in the same company town, or from one company to another. Shelton failed to attribute the latter to lay-offs, firings, or evictions. In addition, they had little regard for their company houses, sanitation, or education and illiteracy, emotionalism, individualism, and fatalism bound miners to a life of misery. They believed that they were doomed to live out their days in the mines and expected their sons to do the same. Few parents had any aspirations for their children or exercised parental control. Thus, while a few miners were respected members of the community who lived in "beautiful homes with obedient children," the "others" lived on the fringe of the community and its institutions. ${ }^{38}$

By the time of the Paint Creek-Cabin Creek strikes, West Virginia miners had abandoned the company churches as miners, whether native, immigrant, or migrant, discovered that the company churches did little to address their spiritual needs. In a like manner, the miners of Harlan County turned their backs on the operators' churches, and flocked to the growing number of independent holiness churches springing up throughout eastern Kentucky. Holiness-Pentecostal churches and sects experienced tremendous growth in the coal regions during the 1920s and 1930s. ${ }^{39}$ Scorned by American Protestantism, Holiness-Pentecostal churches were relegated to the fringes of society. The unique characteristics of working underground, poverty, and lack of education placed miners in the category of "other." Belonging to churches in the fringe only heightened their sense of otherness. Thus, as miners and believers saw their culture marginalized,

\footnotetext{
${ }^{38}$ Shelton, “An Investigation,” 20-25.

${ }^{39}$ The growth of these churches will be discussed in detail later on in this chapter.
} 
they were regarded as working class people, who were ignorant, unable to help themselves, and in dire need of saving on all fronts. ${ }^{40}$

Such a pronouncement had the potential to put them at the mercy of coal operators, mission workers, relief workers, and social justice activists. Outside organizers from the National Miners Union and observers from organizations such as the American Civil Liberties Union brought with them the same perceptions as early mission workers. Even worse in the eyes of mountaineers was the fact that many of the individuals from the above mentioned organizations were atheists or agnostics, who had no theological blanket at all. That conflict would occur was inevitable. When the full effects of the Depression descended upon the coal fields, miners did not seek encouragement and direction from the mission workers or their denomination's local churches.

Methodism continued to be the most prominent of the Protestant denominations in Appalachia, but even the Methodist Church had to confess that its failure to get "miners out of bed and into church,” was almost complete. ${ }^{41}$ Instead, as theologian Robert Livingston discovered when he studied the role of the Presbyterian Church in Logan County, West Virginia, nearly a century later, most miners scorned mainline Protestant churches located in company towns. However, they also avoided mainline churches in independent towns as well since these churches typically strove to remain "neutral”

\footnotetext{
${ }^{40}$ McCauley, Appalachian Mountain Religion, 18, 24.

${ }^{41}$ In 1929, Mary Duprey visited Harlan County as a member of the United States Department of Agriculture's survey of religion, churches, and missionary works in Appalachia. In her report, Miss Duprey stated that "The mountain situation in Kentucky is much worse in regard to religious sects than in any other southern state... the worst mess is in Eastern Kentucky. Preachers preach with a holy twang. Hollerism pretty strong; the fruit of neglect on the part of religious forces in charge. All mountaineers could be reached by Methodists or Baptists if they would try.” Berea College, Southern Appalachian Collection, Appalachian Religious Survey MSS, Extracts From A Study of Harlan County, November 1929, Box 4, fol 3-4.
} 
during times of industrial strife. In addition, the theology espoused by these churches reflected the beliefs of the elite, which, in coal towns, meant owners and management. Livingston found that, as with other coal counties across Central Appalachia, the preferred miners' church in Logan County was the Freewill Baptist. Independent, holiness churches such as the Freewill Baptist Church primarily appealed to the working class. Since these churches were autonomous and practiced free church polity, they were usually shepherded by one of their own, a miner who, upon receiving the call from God, constructed a church on his own property where he preached the Word of God on Sundays and mined coal the rest of the week. ${ }^{42}$

Miners had another reason to avoid the company church. While a few operators were genuinely concerned with their employees' souls, most viewed the church as a tool that could be used to produce a more responsible and productive work force. Mountain churches had long been known to serve as the "invisible hand of the law" in settlements that were too far from the county sheriff to visit on a regular basis. When a need arose, a congregation met and collectively assumed responsibility for church discipline where the accused was presented with the charge against him. He could either deny the charge or acknowledge his transgression and ask for forgiveness. Most of these assemblies dealt with matters that were directly associated with holy living such as nonattendance or failure to observe some form of the church's rules of decorum. The church exerted its influence beyond its own congregation to the community at large. Both clergy and members of the congregation used moral persuasion to control the mores and attitudes of the community by appealing to the religious values and associations within the

\footnotetext{
${ }^{42}$ William John Bryant Livingston, “Coal Miners and Religion: A Study of Logan County, West Virginia” (Ph.d.,diss., Union Theological Seminary, 1951), 226-227.
} 
community. Prior to industrialization, many churches, especially the Baptists, had a greater influence in the community than civil authorities, political parties, or businessmen. $^{43}$

Industrialization had certainly changed the demographics of mountain communities, but the religious values of the native population as well as those of a majority of its newcomers remained the same. The Gospel could be used to reinforce values that were of great benefit to the workplace and the operator's bottom line. Backed by the authority in the Scriptures, clergymen could preach the spiritual value of hard work, thriftiness, sobriety, and loyalty to one’s employer. As a result, more than one tight-fisted operator turned into a cheerful giver, dug deep into his pockets, and generously contributed to the churches of his town. Some were more generous than others, especially during a strike when profits as well as public opinion were on the line.

In November 1919, the United Mine Workers of America called a nationwide strike, hoping to increase wages of miners who were, like most Americans, feeling the pinch of the post war recession. In Harlan County, nearly four thousand union members halted 60 percent of the county's production and closed all major mines except those of Wisconsin Steel Company and U.S. Coal and Coke Corporation. Miners remained on strike after the operators rejected the national contract, removed checkweighmen from their tipples, refused to deduct union dues, and fired, and evicted union miners. The operators extended a carrot to the miners and offered wages well above the union scale. The miners refused, and the operators increased their use of the stick. The murders of several miners and deputy sheriffs threatened to tip the cart of public opinion in favor of

\footnotetext{
${ }^{43}$ Durwood Dunn, Cades Cove: The Life and Death of a Southern Appalachian Community, 1818-1937 (Knoxville: The University of Tennessee Press, 1988), 109-111.
} 
the union. During this period, “A Union Man” sent the United Mine Workers Journal a report on the violence inflicted upon the miners who worked at the Banner Fork Coal Corporation’s Mine No. 2 from March-May. In it, he stated that a coal operator donated $\$ 25,000$ to a church in Jellico, Tennessee. Shortly after the donation was received, the operator began employing gunmen in his camp. One of his gunmen was Rockingham Smith who was tried, convicted, and sentenced to twenty years in the penitentiary for the murder of two boys. Coal operators used their influence in the judiciary and kept Smith home, free to serve as the chief constable of the county court and work for this unnamed coal operator. Evidently, this operator hoped that his generosity would keep some of the county’s finest citizens from grumbling. ${ }^{44}$

Employers, both small business owners and captains of industry, looked to society's institutions, especially the church, for help in ensuring that all members of the community conformed to the prevailing social, economic, and political interests of an industrial society, one that was dependent upon a well-disciplined work force. However, labor historian David Corbin incorrectly minimizes the importance of the many independent holiness churches that sprang up in the hills and mountains that surrounded these company towns. Those living in the new rural-industrial economy responded to the stress that living in the new industrial order produced in a manner similar to their predecessors from the Gilded Age. Miners and farmers turned to churches whose theology had working class roots-Holiness-Pentecostal churches.

Holiness-Pentecostal churches provided an “alternative ideology” in interpreting the "chaotic, rapidly changed world" that Americans encountered at the end of the

\footnotetext{
44 “Harlan County, Ky., Gunmen Shoot Down Coal Miners,” United Mine Workers Journal, 1 May 1920, 4.
} 
nineteenth century. ${ }^{45}$ The Holiness movement and Populism were parallel developments during the 1880s and 1890s. Holiness-Pentecostal churches shared many of the same concerns as Populism: feelings of crisis, insecurity, and isolation created by a society in transition. Their "alternative theology" gave farmers and industrial workers another way to interpret a "chaotic, rapidly changing world." ${ }^{46}$ In spite of such shared concerns, few church members participated in the movement, because they feared that political involvement could possibly lead them away from their commitment to the Lord and holy living. Thus, they increasingly focused upon a more heavenly mandate.

During the Progressive Era, the "better people of society" who filled the majority of churches within the Protestant mainstream joined the Social Gospel movement, a movement that emerged at the end of the nineteenth century as the growing middle class became increasingly disenchanted with Social Darwinism and laissez-faire economic policy. Spokesmen for the movement were primarily concerned with the search for a better society. Instead of insisting on the self-sufficiency of individual regeneration through conversion as a solution for social problems, they looked for concrete ways to improve society. Its followers fervently believed that social improvement was possible and a requirement of Holy living. ${ }^{47}$

Determined to create the kingdom of God here on earth, Social Gospelers led the way in a variety of projects aimed at improving the living and working conditions of workers, especially in urban areas. Social Gospelers, especially those who filled the pulpits, were also alarmed at what they perceived as the increasing disinterest and

\footnotetext{
${ }^{45}$ Mickey Crews, The Church of God: A Social History (Knoxville: The University of Tennessee Press, 1990), 2-3.

${ }^{46}$ Crews, The Church of God, 2-3.

${ }^{47}$ Henry F. May, Protestant Churches and Industrial America (New York: Harper \& Brothers, Publishers, 1949), 170-171.
} 
participation of workers in religion. In reality, workers had little in common with middle class churchgoers. Their limited education, inadequate clothing, and opposing world views put workers at odds with the "better people" in the church, a group that included clergymen. While Social Gospelers generally agreed that workers had a moral and legal right to organize, they were unsure about strikes and condemned acts of violence. Instead, they believed that the solutions to labor problems were cooperatives, arbitration, and profit sharing. As individualists and believers in democracy, Social Gospelers agreed with unionists and encouraged workers to join mutual aid societies, especially those designed to provide relief and insurance. ${ }^{48}$ Thus, workers abandoned these churches in in the closing decades of the century. Most of the middle class chose to believe that workers left the church, because they were no longer interested in religion. While modern life did have its tantalizing diversion, the majority of the working class did not leave the church because religion had lost its appeal. Instead of being disinterested in religion, they became members of various Pentecostal sects and churches, a religious movement that, according to H. Wayne Flynt, "fueled a raging fire of Populist and Socialist Radicalism." ${ }^{49}$

The Social Gospel movement flourished in the urban South, despite the opposition of rural people who were critical of its liberal theology. As opponents of liberal theology and proponents of "the old-time religion," they denounced a theology that criticized the Scriptures and promoted humanism. Instead of positively responding to the socio-economic needs of members of the South's "third white class," middle class

\footnotetext{
${ }^{48}$ Howard C. Hopkins, The Rise of the Social Gospel in American Protestantism, 1865-1915 (New Haven: Yale University Press, 1940), 74-75.

${ }^{49}$ H. Wayne Flynt," Southern Progressivism and Reform, 1890-1920," in Varieties of the Southern Religion Experience, Samuel S. Hill, ed. (Baton Rouge and London: Louisiana University Press, 1988), 154-155.
} 
clergy criticized miners and mill workers who filled the pews of sect churches over theological differences. This move only increased the attractiveness of Pentecostalism. Theologian Mickey Crews states that Pentecostalism compensated workers suffering from the effects of deprivation. Of the five types of deprivation suffered by individuals and groups--economic, social, organic, ethical, and psychological-- economic deprivation was a critical factor in the emergence of Pentecostalism. The poor, uneducated, and powerless flocked to Pentecostal meetings during the early days of the movement. They were drawn to the sense of power that was present during these early Pentecostal meetings, a power that was of God and available to all believers, regardless of socioeconomic status. Equally important to individual believers was their ability to access it at any time, whether during their personal prayer times or during worship services. Pentecostal power provided relief in the present, through the fellowship of believers, strength to overcome everyday trials, and solace during frustrating circumstances. More important to believers were the rewards promised to them in heaven. ${ }^{50}$

The growth of the Pentecostal Church of God (Cleveland, Tennessee) was not directly related to Populism. Instead, it was part of a religious movement that paralleled Populism, the Holiness-Pentecostal movement. For as Vinson Synan notes in The Holiness-Pentecostal Tradition, the very groups which Social Gospelers wanted to help, the underprivileged and the poor, were the very ones who joined the same holiness and Pentecostal churches, groups which vehemently denounced the Social Gospel movement. Holiness people taught a "negative social gospel”; rather than trying to reform society, they rejected it. In the holiness value system, the greatest "social sins" were the effects of

\footnotetext{
${ }^{50}$ Mickey Crews, The Church of God: A Social History (Knoxville: The University of Tennessee Press, 1990), 6-9.
} 
the theater, ball games, dancing, lipstick, cigarettes, and liquor, not poverty, inequality, or the unequal distribution of wealth. Very few proponents of holiness had any desire to reject capitalism, as the most liberal proponents of the movement advocated. Their most serious objection to the Social Gospel movement was the fear that the leaders of the movement would forsake individual salvation and substitute "social works" for "saving grace.”51

These theological, intellectual, and social changes precipitated the complete separation of holiness churches and traditional Methodism. Although many holiness groups began before 1894, the majority were organized during the four years following the 1894 General Conference of the Methodist Church, after the association issued its anti-holiness statement. Of the twenty or more groups that emerged during this brief period, only four would later become Pentecostal. The four groups originated in the South. The two largest holiness denominations that resulted from the National Holiness Movement, the Church of the Nazarene and the Pilgrim Holiness Church, were the products of a complicated series of mergers of holiness groups. These churches included the New Testament Church of Christ (Milan, Tennessee, 1894), the Pentecostal Mission (Nashville, Tennessee, 1898), and the Independent Holiness Church (Texas, 1900). In addition to the Church of the Nazarene and the Pilgrim Holiness Church, dozens of smaller groups came out of Methodism and other denominations during the 1890 s. $^{52}$

At the same time, a major shift appeared among leaders within the holiness movement over the "Pentecostal" aspects of the second blessing. According to John Wesley, the founder of Methodism, believers undergo two, distinct religious experiences.

\footnotetext{
51 Synan, The Holiness-Pentecostal Tradition, 48-50.

52 Synan, The Holiness-Pentecostal Tradition, 48-50.
} 
The first, conversion, was discussed earlier in this chapter. Wesley called the conversion experience the "first blessing" or justification. In the first experience the penitent is forgiven for his sins of commission and becomes a Christian. At the same time, he retains a residual of sin within.” The remaining sin, according to Wesley, resulted from Adam's fall from grace in the Garden of Eden ${ }^{53}$ and has to be dealt with by a "second blessing." When the believer experienced the second blessing, he was finally cleansed of all sin and given "perfect love" toward God and man. ${ }^{54}$ During the 1890s, a major shift began to appear among many holiness leaders emphasizing the "Pentecostal" aspects of the second blessing. One of the leaders behind this change was R.C. Horner. Horner, a Canadian holiness evangelists, founded a radical movement during this period that later produced at least three Canadian holiness denominations. In several books, Horner stated that second blessing sanctification, as taught by John Wesley, did not include a "baptism in the Holy Spirit” as generally understood by the Methodist-holiness movement at large. In his 1891 book, Pentecost, the evangelist taught that the baptism of the Holy Spirit was in reality a third work of grace. This third work or blessing followed salvation and sanctification and empowered believers for service.

In Horner's revival meetings, believers frequently displayed such behaviors or "physical manifestations” such as "prostration,” "ecstasy,” and “immediate laughter," which led to Horner's expulsion from the Methodist Church. The most far reaching effect of Horner's teachings was to separate in time and purpose the experiences of second-blessing sanctification and the "third blessing" of baptism in the Holy Spirit." This third blessing was a further act of God's grace and the power of the Holy Spirit.

\footnotetext{
${ }^{53}$ Genesis 3.

${ }^{54}$ Synan, The Holiness-Pentecostal Tradition, 6.
} 
The evidence of this third blessing was the individual's ability to speak, whether praising or praying to God, in a formerly unknown language and was commonly referred to as the gift of tongues. ${ }^{55}$ This theological distinction became the key to the development of Pentecostalism and led to a change in terminology which can be called "Pentecostal sanctification." Legalistic and emotionally demonstrative holiness denominations arose during the period that later became part of the Pentecostal movement. This took place in the South and Mid West and in much of the same way that Populism displayed its most powerful phase. ${ }^{56}$

Holiness groups broke away from older denominations throughout the nation, and new sects were established in every region. Many of these groups used the term "holiness" in their names, while others preferred the word "Pentecostal.” The most popular name became "The Church of God,' with no less than two hundred organizations adopting some version of this name to designate their churches between 1880 and 1923. The most important sect-forming period in the South occurred between 1894 and 1898. This period followed the anti-holiness policy statement that the General Conference of the Southern Methodist Church issued in areas where new churches preaching the holiness doctrine were calling themselves "Church of God." The only connection between the new churches was the doctrine of entire sanctification, the belief in a person's ability to live a life free from sin, whether implicit or understood, was considered heresy to mainstream denominations. The teaching created quite a stir in communities where it was first preached. ${ }^{57}$

\footnotetext{
${ }^{55}$ Holt, "Holiness Religion,” 740-41.

${ }^{56}$ Synan, The Holiness-Pentecostal Tradition, 50-51; 68-69.

${ }^{57}$ Synan, The Holiness-Pentecostal Tradition, 50-51; 68-69.
} 
The growth of the Church of God and other churches whose traditions fall within the definition of mountain accelerated during the growth of the coal and textile industries in the Appalachian South. Like the Populists, Christians from society’s "lower stratum," especially those living in rural and rural-industrial areas, were looking for a way to rise above their hardships and their place at the fringe of the dominant society. Mountain people had discovered that the fruits of industrialization were bittersweet and had come with a price. Most importantly, Holiness believers felt that the world was in ruins. This was especially true to the vast majority of holiness people who attended the tiny churches that were scattered throughout the mountains of Appalachia. According to religious historian Richard Callahan, one element of mountain religion that Holiness intensified during this period was the dichotomy between the spiritual and material worlds. This view, which is a basic tenet in the doctrines of various churches that fall under the umbrella of mountain religion, holds that the material world is a "transitory place of limitations," opposed to the spiritual world, which is a world without a beginning or an end. Holiness proponents believe that within the human body resides the spirit or soul, the part of a human being that is eternal and bound for either heaven or hell. According to this view, Jesus Christ will return to the Earth to defeat evil, render divine judgment on all people, and reign forever with His followers in an eternal paradise. As the fruits of industrialization became increasingly bittersweet, those who held such a world view saw the end in the not too distant future, evidenced by the increasing interest in worldly things such as wealth, the rejection of traditional worship practices, modern modes of interpreting scripture, and the growing sinfulness of the day, signs that were evident throughout the coalfields. ${ }^{58}$ 
In 1940, sociologist John B. Holt published an article on Holiness Religion in the American Sociological Review. In it, Holt described the growth of the Holiness and Pentecostal denominations or sects in the southeastern states as "phenomenal." The results of his study determined that the seven strongest denominational bodies within the holiness-Pentecostal movement were in order of numerical strength:

1. Assembly of God

2. Church of the Nazarene

3. Church of God (Cleveland, Tennessee)

4. Church of God (Anderson, Indiana)

5. Pentecostal Assemblies of the World

6. Pentecostal Holiness Church

7. Pilgrim Holiness Church

Holt frequently referred to these groups as "holy rollers," a term used in reference to the tendency of believers to roll on the floor when experiencing the power of the Holy Spirit. $^{59}$

Membership in these seven groups was seven times greater in the Southeast and Southwestern regions than in the Northeast and Middle States. ${ }^{60}$ Holt attributed the growth of these particular denominations and sects in these regions to the social

\footnotetext{
${ }^{58}$ Richard Callahan, “Working With Religion,” 177-178.

59 John B. Holt, “Holiness Religion: Cultural Shock and Social Reorganization,” American Sociological Review 5 (October 1940): 740-741.

${ }^{60}$ Holt notes in his article that, according to the Census of Religious Bodies, in no geographic division did the proportion of Holiness and Pentecostal church members to the total church membership (including black churches) exceed three-quarters of one percent. The proportion in 1926 was as follows:

South Atlantic: .75 percent West South Central: .71 percent East South Central: .54 percent East North Central: .48 percent
} 
disorganization suffered by the regions' many migrants who had been forced to leave rural areas in search of work. Many of these migrants relocated to urban areas, or, as in the case of most coal miners, moved to other rural areas. As these workers adjusted to their new living and working environment, they looked for ways to re-organize the personal and social aspects of their lives. Membership in churches such as these aided many migrants in their quest to achieve social re-organization. In their former communities, most workers had been engaged in agriculture and moved to ruralindustrial areas or urban areas to find work in the extractive industries. Upon their rapid exposure to living and working in an industrial setting, migrants typically exhibited signs of culture shock. One administrator of a Kentucky farm bureau equated it to the physical bends that deep sea divers experience when exposed to rapid changes in pressure. According to Holt, rural migrants experienced psychological and spiritual bends as they were subjected to urban standards and ways of doing things. For instance, migrants typically experienced a loosening of mores in their new environment. What constituted as socially acceptable behavior in their new community drastically differed from mores found in a society that strictly controlled the behavior of its members. These workers typically grew up in patriarchal families whose fathers kept a tight rein on their children. While living apart from their families may have been liberating to some, most migrants experienced extreme anxiety while adapting to a new culture without the support and assistance of kin. Although they enjoyed increased wages and the benefits of living in towns with easy access to community institutions and services, migrant workers also found their new environment to be more impersonal than their previous rural environment. In addition, miners found a downside to working in an extractive industry: 
its frequent periods of under or unemployment, a reality that forced many miners to frequently move to find work. Moving from place to place only increased their feelings of instability and isolation. ${ }^{61}$

The greatest blow came for miners when they realized that, in the eyes of the "better people in their community,” that they were non-persons. The status that they had previously enjoyed as farmers, especially in terms of their ability to work independently on a variety of different tasks, had been "blasted away.” They found themselves segregated, economically, socially, and occupationally from the more established groups. As a result, many miners turned to religious sects. Sects, religious groups that were regarded as heretical and a deviant group in the eyes of the Protestant Mainstream, were, according to Holt, manifestations of nature's power to heal. They were the "spontaneous attempts of common people to deal with stresses. The sociologist believed that individuals were drawn to holiness/Pentecostal religion in order to fulfill the need to belong and regain a sense of personal security. Joining such groups was a way to preserve standards and behaviors from their homeland, instead of adopting attitudes and behaviors that fit their new situation.

In 1926, the largest holiness-Pentecostal congregations in the southeast were those of the Church of God, Pentecostal, whose headquarters were located in Cleveland Tennessee. Churches that belonged to the Cleveland group were concentrated in and around large urban or rural-industrial centers, the coalfields of Alabama, Tennessee, and Kentucky, in areas associated with industry, manufacturing, mining, developing agriculture, and low-cost recreation areas with a large white population. ${ }^{62}$ As the table

\footnotetext{
${ }^{61}$ Holt, "Holiness Religion," 743-744.

${ }^{62}$ Holt, "Holiness Religion," 742-44.
} 
below indicates, Holiness-Pentecostal churches such as the Church of God tended to be located in rural areas such as eastern Kentucky rather than in urban areas.

\section{Holiness-Pentecostal and Independent Churches and Membership in Urban and Rural Kentucky in 1936}

\begin{tabular}{|l|c|c|c|c|}
\hline \multicolumn{1}{|c|}{ Denomination } & Churches & Urban & Rural & Members \\
\hline & & & & \\
\hline Assembly of God & 25 & 6 & 19 & 852 \\
\hline Church of God Cleveland & 70 & 12 & 58 & 2640 \\
\hline Church of God Anderson & 48 & 11 & 37 & 2857 \\
\hline Church of God Tomlinson & 37 & 8 & 29 & 1878 \\
\hline Nazarene & 64 & 25 & 39 & 3412 \\
\hline Independent & 13 & 0 & 13 & 773 \\
\hline
\end{tabular}

Information Taken from U.S., Department of Commerce, Bureau of Census. 1936: Religious Bodies, Table 3, vol.1.

The Kentucky Church of God was no longer the “churchless” state as the General Assembly watched its membership in the state grow by ten fold between 1916 and 1936. ${ }^{63}$ In his report to the 1936 General Assembly, State OverseerT. M. Clendon stated that Kentucky now had 88 white and 3 black churches. Twelve of the state's white congregations and its only black congregations were located in Harlan County. ${ }^{64}$

The rise of the sects in Appalachian coalfields provides further evidence of mountain religion’s long legacy of resistance. According to Holt, individuals had different reasons for being attracted to sects, but he believed that the rise of the sects represented a conscious desire to secede from established denominations. This deliberate decision to resist the temptation to join more socially accepted churches paralleled mountain religion's earlier decision to remain outside American Protestantism. The sects'

\footnotetext{
${ }^{63}$ The Church of God of Kentucky, A History 1911-1987 (Charlotte, North Carolina: The Delmar Company, 1988), 150.

${ }^{64}$ Minutes of the 31 $1^{\text {st }}$ Annual Assembly, Church of God General Assembly Minutes, 1906-2002 (Cleveland, TN: Dixon Pentecostal Research Center, 2006)
} 
desire to secede from American Protestantism shows sectarians as reformists who opposed modern theology and the liberalism present in Methodist, Episcopal, Presbyterian, and Lutheran churches. The movement benefited from the migration of workers whose former churches were rooted in the fundamentalist, camp meeting traditions so prevalent in the rural south. Established churches became symbols of isolation and alienation to migrants, ${ }^{65}$ and temples dedicated to the worship of materialism and the maintenance of an industrial society determined to keep them alienated and powerless. The miners who attended holiness-Pentecostal churches truly believed that, ultimately, they were responsible to God, not man. If God called a man to join a union, who was to question it? Their belief in the supremacy of the Bible fueled their radicalism and sanctified their revolution. However, their literal interpretation of the Bible became problematic when it came to membership in secret societies. The leadership of the Church of God (Cleveland) forbade its members, and especially its pastors, to join labor unions, but in time this would change.

The typical member of the Church of God was working class, but its spokesmen were usually prosperous, yeoman farmers and property owners. Such was the case of the founder of the founder of the Church of God, Richard Spurling. Spurling was a major land owner in Polk and Benton Counties in Tennessee where he owned two one thousand acre tracts of land. Although the minister possessed a limited education, like other selfmade men, his limited education did not hinder his rise to the top of the socio-economic ladder. His intelligence, work ethic, and motivation fueled his success. ${ }^{66}$

\footnotetext{
${ }^{65}$ Holt, “Holiness Religion,” 247.

${ }^{66}$ Crews, The Church of God, 6, 18.
} 
During the early years of the Church of God, common religious beliefs transcended matters of class. Members were united by church theology, which included a literal interpretation of the Bible, the Baptism of adult believers, the Virgin birth, the Second Coming of Jesus Christ, and the baptism of the Holy Spirit as evidenced by the speaking of tongues. In spite of their general unity in matters of doctrine, an increasing number of industrial conflicts and the labor question soon placed the church at a crossroads. ${ }^{67}$

The church's stand on labor unions emerged during the meeting of the Third General Assembly in 1908 when the Assembly ruled that members could not belong to lodges. They based their decision on scripture: 2 Corinthians 6:14-17; warned Christians "not to be unequally yoked with believers"; Ephesians 5:4-7, 11 \& 12, warned against “fellowship with unfruitful works of darkness" done "in secret”; 2 Timothy 3:4, 5, called Christians to turn away from those who love pleasures more than God and deny God's power; Mathew 5:34-37, Jesus' injunction to “swear not all”; and James 5:12, which forbade the swearing of an oath., 68

Earlier labor organizations, such as the Knights of Labor, required that its members take a secret oath and included aspects of Masonic Ritual in their meetings. Thus, the Knights and railroad unions such as the Order of Railroad Conductors were also classified as secret societies. In true Masonic fashion, their organizations were called lodges and each member had to know the "current password." Coal miners who attended Church of God congregations encountered the union issue. In 1913, Tomlinson responded to a question from the floor regarding this issue at the Eighth Assembly of the

\footnotetext{
${ }^{67}$ Crews, The Church of God, 48.

${ }^{68}$ Michael Szpack, "Removing the 'Mark of the Beast': The Church of God (Cleveland, Tennessee) and Organized Labor, 1908-1934” Labor's Heritage (Summer 1994): 48.
} 
Church of God. When asked if members could join the "United Coal Miners

Association," he responded with an emphatic "no.” Referring to Revelation 13:17, Tomlinson stated that membership in any union could be equated with the "mark of the beast," symbol of the anti-Christ. ${ }^{69}$

The question resurfaced at the Tenth Assembly in 1914. This time, Tomlinson appointed a committee of six to "consult as to whether members of labor unions should be taken into the Church.” The issue remained "unsettled" but as General Overseer of the Church, Tomlinson "gave a rule to follow for the present": church members were given the "privilege" of paying dues to labor unions as a "tax to purchase the right to work in the mines, factories, and other public works.” However, they were not permitted to "attend or take part" in union meetings. No one who was licensed or ordained to preach could pay dues or have any connection with unions.”

Tomlinson added two questions regarding labor union membership to the ministerial examination certificate prior to the Tenth Assembly ruling. The certificate contained questions designed to ascertain the moral and spiritual characters of applicants for the offices of bishop, deacon, or evangelists. The certificate now included the following: “Were you ever a member of any labor organization?”; “If so, how long since your membership ceased?” Thus, labor union membership was an obstacle to becoming a minister. Tomlinson permitted a compromise on the issue of union membership, but he worked to maintain the church's clergy as an example of his personal opposition to unions. $^{70}$

\footnotetext{
${ }^{69}$ Szpack, "Removing the 'Mark of the Beast," 49; Revelation 13:11-18.

${ }^{70}$ Szpack, "Removing the 'Mark of the Beast," 49-50.
} 
The issue of union membership continued to be a matter of debate in spite of the overseer's opposition. The following year, Tomlinson considered that the matter was now "settled." He repeated his ruling that church members could not voluntarily pay union dues, but if the employer held back wages for any reason, the church member was “not responsible.” Nevertheless, church members who were, in increasing numbers, coal miners, refused to let the question die. In 1917, the Thirteenth Assembly issued a ruling that signaled the pressure that state overseers from coal producing states were most likely enduring as the coal industry ascended to its throne. Referring to "the matter of labor unions" as a much more difficult matter to decide upon than "lodges or secret orders," the church reiterated its determination to maintain its stance on voluntary union membership. Assembly delegates did make an allowance for church members who had no choice but to belong to unions, attend union meetings, or pay their dues. A crack in the Church's wall of opposition had emerged. A year later, Tomlinson emphatically opposed union membership for the fifth time in seven years and refused to amend the Eleventh Assembly’s ruling.

Tomlinson opposed labor unions for a variety of reasons. He believed that unions were havens for godlessness. In addition, he feared that church members would not be able to meet "the gospel standard" as members of organizations that fostered "selfishness... back biting... minding the things of the world." Thus, those who were children of God could not have anything to do with the violence and the flowing of “innocent blood that erupted during strikes. Furthermore, the overseer believed that unions violated the fellowship of the church, especially on the picket line when "innocent men” who wanted to work were called "scabs” and taunted, wounded, and occasionally 
killed by strikers. Thus, instead of being bound by Christian love, Christian brotherhood would be "torn asunder" by the picket line and acts of violence. Because he saw labor unions as "too near akin to the mark of the beast" for him to remain silent.” As a result, Tomlinson felt compelled to maintain the ruling as a "lighthouse" that would remind members that involvement in labor unions might keep them out of heaven. ${ }^{71}$

Tomlinson’s rulings remained in place until 1923 despite regular questioning by members at successive assemblies. Opportunity for change in the leadership and doctrine of the Church of God came at the expense of the general overseer. Tomlinson's downfall revolved around a dispute over the distribution of church funds. Local churches sent their members' tithes to the state overseer and the general headquarters. In 1920, the general overseer proposed that all tithes be sent to the general headquarters where they would be divided, a decision that proved to be a disaster. In 1923, the Council of Twelve- the church's executive body-- impeached Tomlinson for misappropriating funds. The church plunged into turmoil, but Tomlinson refused to relinquish the name "Church of God” and reestablished a group loyal to him. Finally, in 1927, the Supreme Court of Tennessee ordered the former general overseer to change the name of his new church. He did, renaming it as the Tomlinson Church of God. Under the leadership of Tomlinson’s successor, F.J. Lee, the church liberalized its position on labor unions, a move that ensured the continued fiscal health and growth of the organization.

Many Church of God members were coal miners, and the Church enjoyed its greatest expansion in the coalfields of West Virginia and Kentucky. The congregations in these areas transferred their loyalty to the new leadership of the church. State and international leaders knew that upholding Tomlinson's mandate against labor unions

\footnotetext{
${ }^{71}$ Szpack, "Removing the 'Mark of the Beast," 52.
} 
could cause coal field churches to defect. At the Church of God's West Virginia State Convention in 1922, State Overseer E. L. Simmons addressed the "great stir" that was taking place in the union mining districts and the "possibility of bloodshed." The minister noted that the situation was of "vast importance” to the Church. Reverend Simmons was concerned about the plight of union miners whose "financial conditions" were so "bad" that "some of our people" had little food or clothing. While continuing to support the Church’s 1915 position, the overseer advised his fellow clergymen to "be careful" in their relations with unions and urged them to know "that they are always on the right side or not to be on any side at all.” He further reminded them that the general overseer had appointed him to instruct them about the church’s teachings. Simmons exhorted his clergymen of the need to be neutral, lest their "influence” would be affected. As ministers, Simmons warned them against taking sides in labor conflicts. He was especially dismayed that union church members refused to fellowship with anyone opposed to the union. The minister considered such an action a detriment to an individual's salvation. The overseer's remarks indicate that the members of the church in West Virginia challenged the authority of the Eleventh Assembly’s mandate and voluntarily participated in strikes and other union activities. If they had not, he would not have had any need to advise the ministers as he did. As Michael Szpack notes in “Removing the 'Mark of the Beast': The Church of God and Organized Labor," the state overseer recommended neutrality as opposed to a strict adherence to the Assembly's position. $^{72}$

\footnotetext{
${ }^{72}$ Michael Szpak, Unpublished Paper \#125, "Removing the 'Mark of the Beast': The Church of God and Organized Labor, 1908-1934,” 8-9. Quotations from "West Virginia State Convention,” Church of God Evangel 24 June 1922, 4.
} 
After Tomlinson's impeachment, the Church moved toward the neutral position advocated by E. L. Simmons. In an article published in the Church of God Evangel in November 1925, J .S. Llewellyn, who had replaced Tomlinson as the newspaper's editor, proposed that a new approach be taken toward unions. The editor advised church members to use caution in their dealings with unions. However, he openly criticized the actions of the coal operators when he asked, "Which is the lesser evil, organized labor or organized capital?” The Depression had been the result, "no more or less than a capital strike” and was convinced that God loved” the common people because He made more of them.,73

Finally, in 1926, the church dropped the question regarding union membership from the ministerial examination certificate. Among the new leaders attending a meeting that involved the reevaluation of the union question was John Attey. Attey, a former union member, was a member of the Church's executive council from 1924-1926. Two years later, the Assembly lifted its restriction on labor union membership. Nevertheless, its members did not intend for its removal to be seen as an "endorsement" of labor unions. Church members were still advised to join unions only when it was required as a condition of obtaining or retaining employment. However, they were no longer prohibited from attending union meetings or taking part in other union activities. This also applied to ministers who had been formerly forbidden from having anything to do with unions whatsoever. ${ }^{74}$

By 1924, the boom had turned to bust in the West Virginia coal fields, and the Depression years would only exacerbate the hardships experienced by miners and their

\footnotetext{
${ }^{73}$ J.S. Llewellyn, “The Need of the Hour,” Church of God Evangel 28November, 1925, 1.

${ }^{74}$ Szpak, Paper \#125, 9.
} 
families. In a 1930 article in the Evangel, Brother S. B. McCane, of Crown, West Virginia, told readers that "work is bad," and that the rich only increased its oppression of the poor by cutting the wages of working men. In the coal fields, miners were only working two or three days a week. ${ }^{75}$ In the same year, General Overseer Latimer reflected on the Assembly's position regarding union membership and declared: “The Assembly has decided that miners who belong to a union where they have to belong to hold their jobs, where they take no part in strikes and indulge in [no] fighting and confusion, that they may hold their union cards in order to provide a living for their families.” This position also applied to those employed in other industries as well. ${ }^{76}$ As the Depression intensified, more often than not, editors of the Evangel expressed feelings that ranged from deep distrust to outright hostility toward the economics that had caused the Great Depression. E. C. Clark, who became editor of the Evangel in 1932, declared that “if the mines, mills and factories would abide by God's order, overproduction would cease."77 In several instances, writers used the word capitalist in a clearly uncomplimentary sense. In one article, E. C. Clark criticized American corporations that had accumulated their enormous wealth through unfair pricing practices. In it, he told his readers of a coal company, the subsidiary of a utilities company that sold its coal at a higher price to its parent company. Such actions surely led Clark to state that the country's “industrial machines" left no room for "honest independent enterprise."78

\footnotetext{
${ }^{75}$ Szpak, Paper \#125, 9-10. Quotation from S. B. McCane, “Oppressions and Trouble," Church of God Evangel 12 July, 1930, 1-2.

${ }^{76}$ Szpak, Paper \#125, 10. Quotation from S. W. Latimer, Book of Books,” Church of God Evangel 2 August 1930, 3.

${ }^{77}$ Szpak, Paper \#125, 10. Quotation from E. C. Clark, "The Coming Crisis and the World Economic Conference,” Church of God Evangel 5 August 1933, 3.

${ }^{78}$ Szpak, Paper \#125, 10. Quotation from "Past, Present, and Future, Church of God Evangel
} 
Unlike the rest of the Appalachian coalfields, the Harlan County coal field remained relatively healthy throughout the 1920s because of its large number of captive mines. Nevertheless, the Great Depression finally brought an end to the coal boom in eastern Kentucky in 1931, and with it would come a reorganization of the UMWA. New Deal legislation such as Section 7 (a) and the Wagner Act invigorated the labor movement throughout the coal fields, and the union regained membership that it had lost during the previous decade, from poor economic conditions and employer opposition. The number of Church of God congregations in the coal fields of Kentucky and West Virginia continued to climb as well. By 1935, of the 93 churches in Kentucky, 57 (61 percent) of them were in coal mining areas. Of the 111 churches in West Virginia by 1935, 81 (73 percent) were located in coal mining areas. ${ }^{79}$

In the mountains of eastern Kentucky, most of the congregations were very small and isolated from one another, and a scarcity of pastors existed as well. Because of this, small groups of believers frequently met in one another's homes, holding prayer meetings and worship services, until a pastor and suitable location for a church could be located. In many instances, congregations secured a church building for some time before obtaining a pastor. In these situations, a church clerk was named to handle correspondence and financial obligations and visiting evangelists, pastors from the surrounding churches, and members of the congregation preached at Sunday services and revival meetings. Several churches often united for convention-type services as well.

\footnotetext{
1 December 1934, 6.

${ }^{79}$ Szpak, Paper \#125, 11. Szpak compiled his figures, using Church of God: Minutes of the Thirtieth Assembly (Cleveland: Church of God Publishing Company, 1935) and the 1936 Coal Mine Directory (New York: McGraw Hill Publishing Company, 1936).
} 
Churches of God in Kentucky functioned in this manner in the first decade of the church's existence. ${ }^{80}$

Because of the state organization's lack of resources and organization, church historians have labeled the period 1911-1914 in Kentucky as the period of "The Churchless State.” ${ }^{\prime 1}$ In his annual report to the Sixth Annual Assembly in 1911, A.J. Tomlinson, the General Overseer of the Cleveland, Tennessee-based church, noted that some organization had taken place in Kentucky in the past year. During its series of January meetings, the National Assembly declared Kentucky to be an official "state" in the organization and named Sam C. Perry, a former member of the South Florida Holiness Association, the Kentucky state overseer. In spite of this, there is no record of any "official" ${ }^{82}$ congregations within the state until $1915 .{ }^{83}$

After World War I, the Church of God grew rapidly in Kentucky, especially in coal-rich eastern Kentucky. Holiness people began holding meetings between 1910 and 1912, and the first official church in Harlan County was established in Harlan Town in 1917. By 1920, Kentucky church officials were receiving numerous requests for evangelists and preachers who were willing to hold revival meetings and establish new churches in the state’s "new fields." ${ }^{, 4}$ However, the views of George T. Brouayer, the overseer of Kentucky, threatened to disrupt growth in the coalfields because he did not support the Pauline tradition. In letters sent in 1920 to Kentucky ministers through the

\footnotetext{
${ }^{80}$ The Church of God of Kentucky: A History 1911-1987 (Charlotte, N.C: Delmar, 1988), 150-154.

${ }^{81}$ The Church of God of Kentucky, 150.

${ }^{82}$ According to the authors of The Church of God Kentucky: A History 1911-1987 "official” indicates that a church was listed in the church/clerk directory of the Annual/General Assembly Minutes,” 151.

${ }^{83}$ The Church of God of Kentucky: A History, 1911-1987, 150-155; Minutes of the Sixth Annual Assembly, 3-8 January 1911, Cleveland, Tennessee; the General Overseer's Annual Report. Church of God General Assemblies Minutes, 1906-2002 (Cleveland, Tennessee: Hal Bernard Dixon, Jr., Pentecostal Research Center, 2006)

${ }^{84}$ The Church of God of Kentucky: A History, 1911-1987, 155, 178.
} 
church's international publication The Evangel, the overseer criticized licensed ministers who preached the gospel and worked in the mines or other types of manual labor. Having an occupation outside the church was disobedience to the Lord, a "stumbling block for the members," and worst of all, a sign that these men were not truly "called of the Lord to preach.” Furthermore, the overseer feared that their congregations might withhold their tithes: "As long as you ministers work side by the side of the members of the church they will not feeling like paying their tithes into the church when the ministers are the ones who receive them, and perhaps they are making as much and sometimes more than the members. Therefore the cause is hindered on every line.»85

The overseer further reminded them of God's promise to the faithful in Philippians 4:19:"But my God shall supply all your needs according to his riches in glory by Jesus Christ.'(not by manual labor)" ${ }^{86}$ Such a position surely offended the majority of the church's clergy in the state who were shepherding small, working class flocks in rural areas, unlike Reverend Brouayer who oversaw the churches from the bluegrass city of Louisville. That Brouayer alienated his working class preachers is evident by their response to his calls for district meetings. The overseer set the time and place for district meetings, designed to instruct the ministers and the "edifying of all.” The overseer may have taken "the time and expense" to travel to the meeting place, but the ministers did not. Their apparent lack of support did nothing to soften his position. By the end of the year, the overseer Reverend Brouayer informed the churches in Kentucky that he would

\footnotetext{
${ }^{85}$ The Church of God Evangel 7 February 1920.

${ }^{86}$ The Church of God Evangel 7 February 1920.
} 
be leaving his office and the state. Although he dearly loved the churches of Kentucky, he would do so in obedience to God. ${ }^{87}$

In January 1921, Reverend E.W. Gammon became the state overseer. Gammon belonged to the Somerset church in Pulaski County. ${ }^{88}$ As a resident of rural, southeastern Kentucky himself, Gammon was bound to be more sensitive to the needs of the majority of the church's pastors. During the postwar period, most of the church's greatest growth occurred in rural areas home to small farmers and miners, which made up the majority of the working poor. Because of this, few men found themselves leading congregations that could afford to tithe, especially in the amount required to support a minister and his family. To feed and clothe their families, these men followed the tradition of St. Paul and worked with their hands while they fished for men’s souls.

By the early 1930s, the United Mine Workers of America began a series of organizing drives in Southern West Virginia and Eastern Kentucky, an area that was home to powerful operator associations, determined to thwart organization at any cost. The region was also home to the highest concentration of Church of God (Cleveland, Tennessee) churches in the country. ${ }^{89}$

This dissertation will show that the parallel growth of Church of God and the United Mine Workers is no coincidence. The growth of the Cleveland Church of God, and the Church of God Mountain Assembly, in the coal counties of southern West Virginia and Eastern Kentucky occurred at a tumultuous time of crisis. The denomination responded to the crisis, and its corresponding growth was no accident.

\footnotetext{
${ }^{87}$ The Church of God Evangel 7 February 1920.

${ }^{88}$ Bobby Harold Williams, "Early History of the Church of God in Kentucky,” 1968. Hal Bernard Dixon, Jr., Pentecostal Research Center, Information Files, Church of God - Cleveland, Tennessee- Kentucky.

${ }^{89}$ Michael Szpack, "Removing the Mark of the Beast," 46-57.
} 
Holiness-Pentecostal sects and churches such as the Church of God demonstrated the working class' discontent. Moreover, their involvement in the labor movement proves that mountaineers were not religious fatalists, as proponents of the long-held stereotype have led us to believe. These churches grew because their leaders responded to the crisis and refused to tell their members to be faithful, accept their lot in life, and look forward to a better life in heaven. Instead, their preachers became part of the revolution and encouraged their membership to do the same. These churches helped empower coal miners and put an end to their acquiescence. ${ }^{90}$

\footnotetext{
${ }^{90}$ See Michael Szpak, "Removing the 'Mark of the Beast': The Church of God (Cleveland, Tennessee) and Organized Labor, 1908-1934,” Labor's Heritage (Summer 1991): 46-61, and Bryant Simon, “'I Believed in the Strongest Kind of Religion': James Evans and Working-Class Protest in the New South,” Labor's Heritage (Fall 1992): 62-77. Both Szpack and I believe that his data indicates that the churches in the coal producing states, particularly in the case of West Virginia, were responsible for the removal of the restrictions on the union participation of its members and pastors from the denomination's by-laws. With the number of churches in West Virginia increasing more rapidly than those in any other state, the continued support of these churches (financial and spiritual support) would have been jeopardized if these restrictions had not been lifted. The majority of these churches were located in the coal producing areas of the state, in or near the state's large number of coal towns.
} 


\title{
CHAPTER 2
}

\section{POWER AND CONFICT: QUIESENCE OR REBELLION?}

\author{
"To hold their ground, the poor of Appalachia \\ relied less on guns and dynamite than on an \\ inner dignity preserved by a culture of \\ dulcimers and Jesus, \\ front porches and squirrel hunting." 1
}

The tradition of resistance inherent in mountain religion afforded both laity and clergy a valuable education. The religious culture and the resources inherent in the traditions of mountain religion originated from the church house, but they were not contained within the confines of the building. Rather, religious values and practices did not end at the church door but were interwoven with the facets of everyday life. ${ }^{2}$ As a result, the mountaineer's religious beliefs and experiences found their way to the coal's face, the local union hall, and the picket line, and provided the resources necessary to establish and sustain the labor movement in the bloodiest county in the coalfields- Harlan County, Kentucky. At the forefront of the movement stood the miner preachers, men who preached a working class theology that sanctioned the miners' rebellion. In doing so, these miner preachers were ahead of their time. They were practicing liberation theology long before it became a way out of poverty and oppression for people living in Latin America and a topic of bitter debate in America's Catholic churches.

Both mountaineers and the thousands of Southern blacks who migrated to the Appalachian coalfields adhered to a value system which was derived from a

\footnotetext{
1 “Special Report: Harlan County, 1931-1976,” Southern Exposure (4: 1-2), 91.

2 Deborah Vansau McCauley, Appalachian Mountain Religion: A History (Urbana and Chicago: University of Illinois Press, 1995), 435-436.
} 
fundamentalist religious view which accepted a literal interpretation of the Bible. This was especially relevant if all believers truly desired to obey Christ's command to love others as He loved them — the essence of true brotherhood. Southern and Eastern European miners, who were overwhelmingly Roman Catholic and Eastern Orthodox, did not adhere to the fundamentalist interpretation of the Bible, but this did not prevent them from doing the same. By the 1920s, neither race, country of origin, or religion impeded the formation of working class consciousness, as evidenced by strikes against U.S. Steel in Lynch and the Berwind-White Coal Company in Berwind, Pennsylvania. Both corporations were determined to keep the UMWA out of their operations and employed a judicious mixture in their mines. In spite of their efforts, miners in both company towns struck for union recognition, with local miners and their families making up the backbone in each case. Unfortunately, the international leadership of the union abandoned both the Berwind-White and U.S. Steel miners, and they did not realize their goal of union recognition until the New Deal. Local leadership was crucial in keeping the hope for a union alive. Until the passage of New Deal legislation such as Section 7 (a) of the National Industrial Recovery Act and the Wagner Act protected workers’ right to organize and bargain collectively, company domination, not the formation of working class consciousness, kept the union was establishing a permanent beachhead in these coal towns. In time, the Scriptures provided justification for their belief and involvement in the labor movement. ${ }^{3}$ In essence, Appalachian miners were practicing liberation theology before the phrase was coined during the 1950s. Liberation theology, a theology that espouses a belief in God's desire to empower the oppressed so that they might fight

\footnotetext{
${ }^{3}$ Mildred Allen Beik, The Miners of Windber: The Struggle of New Immigrants for Unionization, 1890s 1930s (University Park: The Pennsylvania State University Press, 1996), 119, 123.
} 
for their own liberation, was the solution to the widespread political and economic oppression of the working class in Latin America. Appalachian miners were practicing the tenets of liberation theology long before, Gustavo Gutierrez, the founder of liberation theology, began laying the groundwork for its international emergence. Its proponents argued that social change was a natural product and the central element of Christianity. Therefore, faith in God could empower those who were enslaved by the bonds of economic and political oppression to fight for their own liberation. ${ }^{4}$

Proponents of liberation theology stress that the impetus for change and the leadership must both emerge from the people themselves. The potential power of the grassroots-based movement is one of its main creeds. This is the defining feature of liberation theology and the long-ignored story of the labor movement. Thus, under liberation theology must originate from the voiceless "other," and poor themselves. The belief in an oppressed groups' right to revolt in order achieve true economic, social, and political equality to be realized provided justification for the right to organize. Gutierrez and other proponents of liberation theology believe that one's spirituality must include more than a change of heart. Every Christian must:

1. Believe that God loves all people, regardless of socioeconomic status.

2. Interpret God's Word from his own cultural world and develop his own theology. If the Scriptures are not understood in the context of "real life," one’s spiritual beliefs will be powerless to liberate in body, mind, and spirit. As a result, the Bible provides believers with a lens in which to view history

\footnotetext{
${ }^{4}$ Gustavo Guttierez and Richard Schaull, Liberation and Change (Atlanta: John Knox Press, 1977), 172173.
} 
and contemporary world conditions and forces people, regardless of class, to "discover" the "other people” and question the existing order.

3. Agree that the Gospel calls people to recognize their sinful nature and need for repentance in order to be reunited with God. Support the idea that Jesus Christ’s Crucifixion made total liberation possible for all people, regardless of class or wealth. His death on the cross not only made freedom from sin possible, but it also provided the means by which mankind can be liberated from the last root of sin, social injustice. ${ }^{5}$

Consequently, liberation theology calls for an independent church whose authority lies within the local congregation who are willing to "rip the Gospel from the hands of the powerful." Liberation theology is a "liberating praxis of love" as it calls its followers to love one another and to practice true brotherhood as Christ taught His disciples. In addition, its proponents argue that the Scriptures do not justify the oppression of the voiceless. On the contrary, they point to Christ's association with the poor and oppressed. Thus, while the aim of liberation theology was clearly not intended to provide justification for positions previously taken, such as the Social Darwinist explanation for the parallel growth of poverty and prosperity at the turn of the twentieth century, it was also originally not intended to be a "revolutionary Christian ideology.” 6

Going up against those whose very power and prosperity is linked to the maintenance of the status quo requires actions that will be deemed as radical and sometimes revolutionary even if the intent is to reform the present order, not overthrow it. For the miners of Harlan County, organizing under the banner of the United Mine

\footnotetext{
${ }^{5}$ Guttierez and Schaull, Liberation and Change, 78-83.

${ }^{6}$ Gutierrez and Schall, Liberation and Change, 83.
} 
Workers of America meant an end to their quiescence. No longer were miners willing to give up their civil rights in exchange for employment and housing. The Harlan County Coal Operators Association had more than a million dollars in its war chest, a fund that had been created to keep out the United Mine Workers at any price. Their money bought the support of politicians, from the county court house to the state house in Frankfort.

Harlan County miners were well aware of what they were up against. They would have to use every resource at their disposal if they had any hope of permanently establishing the UMWA in the county. For miners, their most important resources came from their religion. Mountain churches and miner preachers played a key role in a series of mine wars between 1931 and 1939, that were, in every sense, a series of wars over power and position within the community. To understand the role that religion played in the mine wars, I will be using Antonio Gramsci’s Model of Class-Based Opposition and Sociologist Dwight Billings’ guidelines for the historical analysis of conditions under which religion promotes either social quiescence or opposition. Their work provides us with the means to analyze the events of the mine wars and demonstrate the key role that mountain churches and their miner preachers played in developing and maintaining the miners’ rebellion.

As Dwight Billings points out, religion proved to be a critical factor in both stifling and promoting working class rebellion in the South after World War I. ${ }^{7}$ In Harlan County, the miners' religion justified their rebellion while their churches provided the resources necessary to wage a long-term war with the Harlan County Coal Operators Association. As a voluntary institution, the church acts to "house" those with similar

\footnotetext{
${ }^{7}$ Dwight B. Billings, "Religion as Opposition: A Gramscian Analysis,” American Journal of Sociology 96 (July 1990): 1.
} 
beliefs. The church house provides an autonomous place for meetings and can contribute financially to the struggle. Internal mechanisms that ensure the commitment of its members and the experiences that shape the interests of both individuals and the group are of primary importance. These experiences act as precursors to the formation of groups that can mobilize their resources for action. These experiences and the discursive elements of organized religion are religion's most important contributions. These include the moral authority of the Sunday sermon and official pronouncements made from the pulpit.

American Protestantism contributed the moral, ideological, and leadership resources that either promoted labor unions or reinforced the prevailing conservatism of the South, ideology that was strongly anti-union. As such, it served in its "double function," as "an apology and legitimation of the status quo and its culture of injustice on the one hand, and as a means of protest, change, and liberation on the other hand.”8 Previous scholarship on the relationship between religion and labor evolved around Marxist interpretation. According to Marxist interpretation, a system where conflict is interpreted based upon class differences, religious values reflect capitalist ideology. In doing so, religion contributes to the maintenance of the existing order. Thus, in Marxist sociology, Christianity is a "bulwark of capitalism."9

In order for Christianity to serve as the "bulwark of capitalism," it has to perform the following functions: First, Christianity, namely Protestantism, established the moral authority of the middle class. Since the early days of the Republic, Protestantism created a "mood of internal restraint" that served the needs of the wage labor system. Second,

\footnotetext{
${ }^{8}$ Billings, "Religion as Opposition,” 2.

${ }^{9}$ Ken Fones-Wolf, Trade Union Gospel: Christianity and Labor in Industrial Philadelphia, 1865-1915 (Philadelphia: Temple University Press, 1989), xiii.
} 
employers used the moral authority inherent in religion to discipline workers who refused to conform to the behavioral standards of the new industrial order. As immigration increased during the nineteenth century in direct response to America's rise to industrial supremacy, increasing numbers of southern and central Europeans created diversity in the religious sphere. This religious diversity, in combination with differences in ethnicity, gender, and nationalism, fragmented the working class and thwarted the formation of working class consciousness. As a result, workers, especially native workers allied with middle class employers of similar faith. Religious values regarding temperance and the Sabbath became bones of contention by the end of the nineteenth century. ${ }^{10}$ As Billings points out, Marxist sociology sharply reduced cultural ideas to solely the direct results of economic forces, a conclusion that is not conducive to the sociology of religion. ${ }^{11}$

Viewing the relationship between religion and labor in such a linear fashion does not reflect the reality of everyday life. Life is not a succession of epiphanies. Instead, it is marked by days characterized by rote action and opportunities for reflection and contemplation. In everyday life, individuals encounter events that require that they make decisions that shape their lives in both the short and long term, decisions that are sometimes made in haste while others are made with great thought. Life is a series of experiences, and it is in this area that Gramsci makes his most valuable contribution to the sociology of religion.

Antonio Gramsci was a Marxist from the generation who believed that the socialist revolution would be the result of class-based political and cultural struggle that hinged upon a short "war of maneouvre" targeted at capturing control of the state. At the

\footnotetext{
${ }^{10}$ Fones-Wolf, Trade Union Gospel, xiv-xv.

${ }^{11}$ Billings, "Religion as Opposition," 4.
} 
same time, Gramsci believed that class struggle in Western industrial societies would not follow the same path. Instead of being a brief "war of maneouvre,” the struggle would resemble what he called a "war of position.” Unlike the war perceived by his peers, Gramsci stated that this war would be characterized by political battles within "civil society" that would take place over a long period of time. He created a political sociology in order to theorize his views, one that centered upon the concept of hegemony. $^{12}$

In capitalist, industrial societies, Gramsci knew that the dominant classes depended upon maintaining balance between two factors, force (coercion) and hegemony (the consent that the subaltern classes "freely give” to elite rule.) However, as Gramsci points out, when those in power either fail to win this consent or lose it, they are forced to use overt forms of coercion such as violence to guarantee compliance. Thus, if a group is to exercise moral and intellectual leadership over society, it must win the support of dependent groups by connecting the interests of these groups with their own. The ability to mold perceptions is an important power resource. If this is going to take place, both groups must have similar worldviews. Thus, as Gramsci points out, class domination is an "intellectual and moral victory," one that is not necessarily the product of economic reality. Like Gutierrez, Gramsci believed the probability of revolution hinged upon the education of the masses. If a revolution is to succeed, both men also knew the value of indigenous leadership in the educational process. These leaders would educate the masses and enable them to formulate a new world view, one that would replace a world view that had encouraged them to "freely" consent to the rule of the elite. This type of education could only take place in "associational free spaces” where workers and their

${ }^{12}$ Billings,” Religion as Opposition,” 4-6. 
leaders could create an autonomous culture and organization capable of challenging the status quo. For subordinate classes whose worldview is constructed through their religious beliefs, as was the case in Harlan County, Gramsci believed that this would not be possible unless their worldview was dramatically transformed. A transformation such as this likens to that of a religious conversion. ${ }^{13}$

Geographically, the Lower South and Appalachia do not share any common ground in regards to their terrain. However, the regions do share similar cultures. Thus, as it did in the South, Protestantism provided the sustenance necessary to maintain the status quo and rebellion. The "double function of religion," with its ability to act as an "apology and legitimization of the status quo and its culture of injustice on one hand, and as a means of protest, change, and liberation on the other hand" is crucial to understanding the role that religion played in Harlan County. ${ }^{14}$

This was certainly the case in Harlan County. Miners first engaged in a war of position with coal operators in 1907. Miners enjoyed a short-lived victory when the leaders of District 19 of the United Mine Workers Association negotiated a contract that covered Tennessee and five counties in southeastern Kentucky. Operators abrogated the contract in 1910. For the next thirty years, miners and operators would battle it out in a war of position that bloodied the ground. These wars of position will be thoroughly outlined in chapters four and five. In the early years, operators successfully used less overt methods to insure their hegemony over miners. Threats of dismissal, eviction, and harassment usually worked to make sure that any type of opposition was short-lived.

\footnotetext{
${ }^{13}$ Antonio Gramsci, Selection from the Prison Notebooks, edited and translated by Quintin Hoare and G.N. Smith. (New York: International, 1971), 229-238, 147-157,330-343; John Lofland and Rodney Stark, "Becoming a World-Saver: A Theory of Conversion to a Deviant Perspective," American Sociological Review 30 (June 1965): 863-864.

${ }^{14}$ Billings, "Religion as Opposition," 2.
} 
Discursive methods were also important keys in maintaining the HCCOA's iron grip on its miners and their families. Operators also used company churches, schools, and unions as well as the local newspaper, the Harlan Daily Enterprise as educational tools in hopes of ensuring that miners' worldview was compatible with their own. In spite of their best efforts, miners had other ideas. As Christians, their worldview would never be wholly compatible with that of the operators.

The arrival of the Louisville-Nashville Railroad in 1910 opened the door to the rapid development of the county's coal industry. In 1911, the first three mines produced more than 17 tons of coal worth a mere $\$ 21,000$. Few could have envisioned the socioeconomic changes that would take place in the county in the next two decades. In 1928, fifty-nine mines produced 14.5 million tons of coal that was valued at more than more than $\$ 25$ million. What were once the most impoverished counties in the state had become Kentucky’s wealthiest. ${ }^{15}$

When the first three mines commenced their operations, operators found it easy to find local men who were more than willing to lay aside their plows for the chance to earn cash wages. As the industry expanded, operators soon discovered that the number of native workers available did not meet their needs. Hence, as they had in the coal field counties of neighboring West Virginia, coal operators advertised in southern newspapers and sent labor agents throughout the South as well as to eastern ports in search of new miners. Since the miners were primarily recruited from nearby counties in the state as well as Virginia, and Tennessee, the population remained relatively homogenous. ${ }^{16}$ The

\footnotetext{
${ }^{15}$ John Hevener, Which Side Are You On? The Harlan County Coal Miners, 1931-1939 (Urbana and Chicago: University of Illinois Press, 2002), 3.

${ }^{16}$ Paul Frederick Cressey, "Social Disorganization and Reorganization in Harlan County, Kentucky" American Sociological Review 14 (June 1949): 390.
} 
1930 census reported that native-born whites still made up the largest part of the population (90 percent). Nevertheless, the demographic fabric of the county was no longer solely woven with white, Anglo-Saxon, Protestant threads. Agents also successfully recruited a large number of black miners from Alabama and black sharecroppers from Virginia, Tennessee, and Georgia. Although the black population of the county made up only 9 percent of the county's population, it was fairly concentrated at U.S. Steel's mining operations at Lynch. Most of the 822 immigrants who came to Harlan were also living and working in Lynch. The county's newest residents produced few truly new ideas or customs. ${ }^{17}$

Nevertheless, the elite would still blame "foreigners" and "outsiders" for the county's labor troubles. In spite of its apparent homogeneity, life in the county was forever changed. Although workers far outnumbered the members of the middle and upper classes, the composition and size of the middle and upper classes reflected the economic transformation of Harlan County. While the county was still largely rural in nature, its economy no longer revolved around subsistence agriculture. The coal industry was king instead. Previously, the Harlan elite were descendents of the first settlers who capitalized on their ownership of the most tillable bottomland. Succeeding generations increased their wealth and power as they increased their landholdings and diversified their economic interests. By 1930, their ranks swelled, to include coal, timber, and railroad operators, engineers, accountants, managers, and other professionals from the outside who were crucial spokes to the county's industrial wheel. Small, local business

\footnotetext{
${ }^{17}$ Michael H. Burchett, “Promise and Prejudice: Wise County, Virginia and the Great Migration” Journal of Negro History 82 (1997): 313-314; Hevener, Which Side Are You On? 3-4; Joe W. Trotter, Coal, Class, and Color: Blacks in Southern West Virginia, 1915-1932 (Urbana and Chicago: University of Illinois Press, 1990), 25.
} 
men, who had formerly found themselves on the outside, quickly prospered as they began catering to the needs of industry. Their newfound prosperity only increased their standing and influence in the community.

Across Appalachia, as well as in eastern Kentucky, the long-time citizens of Harlan County soon found that the fruits of industrialization were not always sweet. The development of the mining industry in eastern Kentucky and its accompanying population explosion destroyed a formerly stable society where the family and the local community had previously been the two basic social units. The most immediate consequence, however, was the disruption of the economic life of the community. ${ }^{18}$ The former rural-agricultural society whose very survival depended upon mutual respect and dependence was gone. In its place was an industrial society where occupation, wealth, and materialism were more important than one’s reputation and integrity. ${ }^{19}$ This was clearly evident in the divide between mountain churches and "their betters," the denominational churches in the model towns of Benham and Lynch, as well as those located in the commercial centers of Evarts and Cumberland. ${ }^{20}$

\footnotetext{
${ }^{18}$ Paul Frederick Cressey, “Social Disorganization and Reorganization in Harlan County, Kentucky,” American Sociological Review 14 (June 1949): 389-390.

${ }^{19}$ Ronald D. Eller, Miners, Millhands, and Mountaineers: Industrialization of the Appalachian South, 1880-1930 (Knoxville: The University of Tennessee Press, 1982), 9-12, 233-35; Hevener, Which Side Are You On? 14-15. 24-27.

${ }^{20}$ In the spring of 1932, the Bell County attorney and a citizens committee invited a committee of clergymen who had petitioned the U.S. Senate to investigate conditions in eastern Kentucky to visit. Among the 21-member delegation was Reverend Reinhold Niebuhr, a renowned Presbyterian minister and theologian. Upon his return to New York City, Niebuhr wrote of his visit for The Christian Century. The title of his article, "Religion and the Class War in Kentucky," and his impressions of the middle class churches in Harlan Bell County are very revealing. In his article, Niebuhr noted that not all of the area ministers had been invited to attend a meeting that was held shortly after they arrived. Nieburh spoke to various members of the community, including miners. In the end, the theologian stated that the conflict between the miners and coal operators was a "class war," with the "poor mining community arrayed against the middle class community...in this warfare the church is pretty unqualifiedly on the side of the operators.” The Christian Century, 18 May 1932, 637-638.
} 
To the operators' chagrin, the number of miners drawn to company-sponsored churches remained small. Besides the Methodist church, miners and their families were increasingly drawn to Pentecostal-Holiness and independent Baptist churches. ${ }^{21}$ Thus, whether native or not, many miners soon parted company with the company church, an action that labeled them as religious dissidents. In doing so, miners found themselves on the fringes of society because of their occupation and religious beliefs. Such an experience would serve them well in future struggles with the HCCOA and their middle class allies.

The middle class certainly looked down upon the Holiness churches in the county, and their members were frequently persecuted for their faith in the public sphere. When UMWA member and miner B.H. Moses met with the New Deal candidate for Judge, Morris Saylor, the mistreatment of holiness people was the first topic to be discussed. As a holiness minister himself, Moses refused to support a candidate who would not guarantee that all of the county's citizens would be treated fairly under his watch. Saylor acknowledged the treatment that Holiness people and their churches received from the sheriff's department and the courts. He recalled times when calls for assistance were left unanswered when they originated from Holiness churches. Saylor promised that if he were elected judge, holiness people would receive fair treatment under the law. Upon hearing this, Moses agreed to support Saylor in the upcoming election. Before the primary, Saylor held a political rally in Moses’ Blackbottom Baptist Church, a church whose congregation was made up of coal miners and their families. Their political

\footnotetext{
${ }^{21}$ Hevener, Which Side Are You On? 2.
} 
participation was rewarded with two sticks of dynamite that exploded at the end of the rally. $^{22}$

B.H. Moses pastored the Black Bottom Baptist Church, the Closplint Church of God, and the Mountain Assembly Church of God in Kenvir before his untimely death in a roof fall in 1939. All three of these churches were located in coal camps, and miners and their families filled their pews. Their members were drawn to these churches because they felt comfortable worshipping with those of the same class and predicament. With a hearty amen, their congregations showed their support of sermons that reminded them on a regular basis that socioeconomic status or wealth meant nothing to almighty God. Instead, God called all to salvation and service, regardless of gender, socioeconomic status, or education. Their preachers pointed them toward Jesus, a carpenter's son, a man who also made His living with his hands, served others out of love, and died for the sin of all mankind. Nevertheless, even the church could not protect them in the wars of position. It could, however, provide miners with the ammunition necessary to wage a fair fight.

For more than a century, scholars and journalists declared that mountaineers were disinterested in religion and community life. Their pronouncement was based upon irregular church attendance and mountain people's shunning of churches within the Protestant mainstream. Yet, the multitude of churches that dot the highways and byways of the region testify to the importance of religion and the church in the mountain community. Frequently, churches of the same theological orientation were located within earshot of one another. Thus, the people enjoyed an unintentional benefit-- easy access to church. In addition, blacks and whites typically had their own churches. As a result, it

\footnotetext{
${ }^{22}$ U.S., Congress, Senate, Subcommittee on Violations of Free Speech and Rights of Labor, $75^{\text {th }}$ Cong., 1st sess., 1937, LFSCH, pt. 10, 3498-3499.
} 
was not uncommon to find, for example, more than one Church of God, in the same coal camp or town. This was the case in the commercial town of Evarts. Evarts had two Church of God (Cleveland) churches: one white and one “colored.” ${ }^{23}$ Typically, the members of white and black congregations frequently attended one another's revival services and other special meetings. Collective experiences such as worship services, prayer meetings, and opportunities for fellowship in the form of church suppers, revival meetings, funerals, and weddings provided these Christians with opportunities that would foster the spiritual and emotional growth of the individual and the solidarity of the group itself.

Unlike company churches that were constructed and maintained with company funds, the congregations of the independent holiness churches raised the funds necessary to build their churches, and their pastors were one of themselves. As a result, church members were free to use their church buildings and grounds to meet any type of need that the church body or community may have had. This included using the church to hold labor meetings, rallies, or as local meeting halls, and to serve as relief distribution centers and soup kitchens. In doing so, these churches provided free spaces where miners could receive instruction on the benefits of union membership, hold union meetings, and plan organization strategies. In doing so, they developed a new world view and vision of the future. For rank-and-file workers and their leaders, having the freedom to engage in such interchanges is one of the key ingredients necessary for revolution.

According to Antonio Gramsci, the success of any revolution hinges upon the education of the masses, and a redefinition of the workers' worldview. The Harlan miners, whether native or immigrant, believed in American democracy and capitalism

\footnotetext{
${ }^{23}$ General Assembly Minutes, 1934 Annual Assembly.
} 
and had no desire to overthrow the county government or seize the mines. Thus, they were not participating in a true revolution. Instead, Harlan's miners were fighting for the democratization of the work place and their community, goals that were certainly regarded as anti-American and against the American way of conducting business to those who supported the Harlan County Coal Operators Association. These miners knew that their only hope lie in obtaining a union contract under the United Mine Workers Union. The coal miners of Harlan County needed to realize the value and power in union membership and required many of the same tactics necessary in an actual revolution. Union organizers and their fellow miners preached the Gospel of Trade Unionism from the pulpits of churches that opened their doors to the UMWA. Communally grounded voluntary associations such as churches provide an environment where individuals and groups discuss ideas and plan for change without fear of retribution. The ability to freely engage in such an exchange is the basis of any democratic movement. When individuals gather together as a group in a democratic setting, they draw their strength, vision, and power from one another. In the process, their view of the world is transformed, and the group begins to realize that change is possible. ${ }^{24}$ As a result, miners, who had once believed that they had no choice but to acquiesce to the dictates of the operators, were now empowered and filled with hope. Equally important, union miners who had taken the oath in solitary secrecy, were now part of a brotherhood, whose fabric was woven from threads spun in the mill of working class consciousness and the church of brotherly love. ${ }^{25}$

\footnotetext{
${ }^{24}$ Couto 184-186; Gramsci, Prison Notebooks, 324, 330, 333, 339.

${ }^{25}$ Gramsci, Prison Notebooks, 324, 330, 333, 339.
} 
Gramsci and Gutierrez both believed that a revolution would only succeed only when indigenous leaders were in charge of the educational process. Miner preachers made indigenous leadership and education possible. As members of the same cultural group and subject to the same oppression, miner preacher/organizers could design educational strategies and materials that would fit the characteristics and special needs of their group. Gutierrez and Gramsci further believed that indigenous leaders gained valuable assistance when they were allied with other intellectual allies. In Harlan, local men stood at the forefront of organizing drives during the thirties, especially after George Titler arrived in the county in 1937. However, they were aided by international organizers. Such an alliance could greatly enhance and solidify an oppositional worldview that would gain popular support and hegemony. For subordinate classes whose worldview is constructed through their religious beliefs, as was the case in Harlan County, this would not be possible unless their worldview was dramatically transformed. A transformation such as this likens to that of a religious conversion. In the education of these workers, the emotional fervor and religious rhetoric used by their fellow miners and preacher organizers were powerful tools in the conversion process. ${ }^{26}$

Such was the case in the baptism of scabs. When the power of persuasion failed to convert a scab, miners sometimes took the backslider to a nearby creek and "baptized" him "in the name of the Father, the Son, and John. L. Lewis." Usually, this was all it took to convince a scab of the error of his ways, and he immediately "took the oath" of union membership. This was especially true for miners who had either long resisted

\footnotetext{
${ }^{26}$ Gramsci, Prison Notebooks, 330, 333;
} 
union membership or had "blackslidden" [sic] and become company scabs and crossed the line during a strike. ${ }^{27}$

Both U.S. Steel and International Harvester used both the carrot and the stick to keep out the union. When asked about union organizing in Lynch, Alfonso Simms recalled, “They didn’t go for no union man... the company, didn’t want no union either.” However, as Simms learned, not belonging to the union could be just as difficult: "If somebody caught you and you weren't a union man, they'd baptize you in the name of John L. Lewis... They'd drag you down to a creek bank, hold you under water, and ask if you believed in John L. They didn’t drown nobody [sic]. They just held them under water until they said they believed.” ${ }^{28}$

Few miners needed such a baptism however. Miners and their families enthusiastically responded to invitations to attend union meetings and rallies as well as political rallies held to support pro-labor candidates, whether they were held in churches, public buildings, or open fields. Nevertheless, those that were held in coal camp churches most certainly exhibited a fervor that was both emotional and spiritual. In offering their buildings to the union, independent, mountain churches frequently suffered fates similar to those churches established during the New Testament period of the church: their members were persecuted and their meeting places desecrated.

Churches that supported the organizational drives in Harlan County usually paid a great price. Such accounts will be thoroughly discussed in chapter 5 . However, the experience of the community church in Alva is typical of the danger that could result when collaborating with "the enemy." The burning of the church in Alva may have been

\footnotetext{
${ }^{27}$ Thomas E. Wagner and Phillip J. Obermiller, Appalachian Migrants and Miners: The Eastern Kentucky Social Club (Urbana and Chicago: University of Illinois Press, 2004), 76-77.

${ }^{28}$ Wagner and Obermiller, Appalachian Migrants and Miners, 76-77.
} 
the first such incident to occur during the Harlan County mine wars, but, unfortunately, it was not to be the last.

On Sunday, March 1, 1931, the United Mine Workers Union held a rally in a theater in Pineville, where more than two thousand Harlan and Bell County miners listened to UMWA national vice-president Philip Murray speak on the reorganization of District 19. The dismissals began the following morning after company spies reported the names of the miners who attended the rally. The Harlan-Wallins Coal Corporation fired 49 miners, Black Mountain Corporation more than 175, and Black Star Coal Company fired 60. Black Star Local 4027 began holding its meetings at the community church in the company town of Alva. The local would soon be forced to find a new location, however. Soon after the local began holding its meetings in the church, it mysteriously burned. ${ }^{29}$

Churches such as the one at Alva provide a critical resource to the sustenance of a group over a long period of time: the plausibility of belief. During the darkest days of an organizational drive, when a miner grew weary of the long hours spent on the picket line, the violence, and hunger, the church reminded him that his contribution and sacrifice was crucial to winning the fight. The miners' faith in God and the truths that they found in the Bible, reminded them that "with God, all things are possible.”30 Many miners claimed this verse as a promise from God. Thus, if they continued to faithfully obey God's Word and the leading of the Holy Spirit, God would answer the prayers of the mining community. Encouraged, miners and their families believed that, with God, even the union could finally be established in bloody Harlan

\footnotetext{
${ }^{29}$ Hevener, Which Side Are You On? 34.

${ }^{30}$ Matthew 19:26.
} 


\section{CHAPTER 3}

\section{LABOR UNIONS AND RELIGION: UNLIKELY BEDFELLOWS WITH A LONG HISTORY}

During the First Industrial Revolution, first generation immigrants made up the majority of industrial workers in America. Most were formerly indentured servants, men, women, and children, who agreed to reimburse their passage money with their labor. Usually, they worked under their master's control, without wages, for a set term of years. They came from a cross-section of the British working classes, from paupers to the gentry, both unskilled and skilled. For those who faithfully served out the term of their

indentured servitude, there were rewards. Masters frequently sent them on their way with gifts of articles of clothing, tools or livestock that would enable them to start farming on their own. A fortunate few received grants of land and found success as independent farmers. More often than not, most joined the ranks of the rising numbers of unskilled and semi-skilled workers whose hands operated the mines, mills, and factories that dotted the landscape in increasing numbers as the eighteenth century came to a close.

For most workers, the fruits of industrialization were more often bitter than sweet. Most workers labored long hours and earned paltry wages that barely covered the necessities. Struggling to survive on such wages certainly guaranteed that most would remain landless, a condition that left them without the right to vote as well. The vast majority of the new republic's industrial workers had no prior experience with such a world. Without, as E.J. Hobsbawm declares, a “pattern of life suited to the new age,” the first generation of industrial workers "drew on the only spiritual resources at their 
disposal, pre-industrial custom and religion.”1 As historian Catherine Brekkus points out in her book Strangers and Pilgrims: Female Preaching in America, 1740-1845, American society experienced periods of religious revival during times of economic, social, and political upheaval and change. The nation experienced two great periods of revival between 1790 and 1845, a time of rapid changes in American culture. While Brekkus readily concurs that there are various historical interpretations of these revivals, she believes that they must also be understood as a response to the anxieties generated by these changes. $^{2}$

The revivals spread across the new republic during the Second Great Awakening, In the decade that followed the War of 1812, the revival became more institutionalized and the camp meeting became a regular part of the American religious culture. By 1830, the more emotional aspects of the revival became little more than a memory as the emphasis switched from religious conversion to doctrine. This heart-felt religion continued to exist and thrive, especially on the frontier and in the South. During the nineteenth and twentieth centuries, periodic awakenings and recessions of the old time religion came and went much like the booms and busts of the business cycle. ${ }^{3}$ The doctrine of Christian perfection, however, was becoming one of the central themes of American social, intellectual, and religious life in the decades leading up to the Civil War. It is little wonder that many of the reform movements intended to elevate American society during this period, such as the women’s rights, the anti-slavery, and labor and

\footnotetext{
${ }^{1}$ Herbert G. Gutman, "Protestantism and the American Labor Movement: The Christian Spirit in the Guilded Age” The American Historical Review 72 (1966), 79, citing E.J. Hobsbawm, Social Bandits and Primitive Rebels: Studies of Archaic Forms of Social Movements in the $19^{\text {th }}$ and $20^{\text {th }}$ Centuries (Glencoe, Ill.: The Free Press, 1959), 108, 130.

${ }^{2}$ Catherine Brekkus, Strangers and Pilgrims: Female Preaching in America, 1740-1845 (Chapel Hill: University of North Carolina Press, 1998), 11-12.

${ }^{3}$ Vinson Synan, Pentecostal-Holiness Tradition: Charismatic Movements in the $20^{\text {th }}$ Century, 2 nd ed. (Grand Rapids, Michigan: William B. Eerdsman Publishing Company, 1997), 14.
} 
temperance movements, were grounded in the tenets of perfectionism. ${ }^{4}$ In time, Christian perfection would leave its mark on the labor movement as well.

The Holiness movement came to a virtual standstill with the outbreak of the Civil War in 1861. As it had in every sphere of society, the war that pitted brother against brother had a profound effect upon America’s churches. The war only temporarily interrupted movements such as these and the American Holiness movement. Once the war ended, the Holiness movement resumed, with more vigor than before. With blood on its hands, the soul of the nation was in dire need of God's saving grace.

Whether Union or Confederate, Americans suffered from the economic, emotional, and spiritual instability that the Civil War created. The Civil War had a profound effect upon America's churches as well. When the war ended, both Northerners and Southerners hoped for a quick return to peace, prosperity, and stability. Unfortunately, this was not meant to be. Reconstruction and the nation's rush to industrialize made the road to recovery long and difficult. In the South, the war left individuals as well as churches searching for ways to experience redemption and become re-integrated into the new social order. The war left churches marked by a "crusade mentality,” and America experienced a wave of revivals that were encouraged and financed by many industrialists who feared that the growing immigrant population would undermine American values and institutions. “Old light” prophets such as Billy Sunday and clergymen across the nation championed the "old time religion.” These preachers

\footnotetext{
${ }^{4}$ Synan, The Holiness-Pentecostal Tradition, 117.
} 
reflected the fears of millions of pious Americans who lived in the nation's cities as well as in the rural "Bible Belt." 5

On the other hand, religious leaders, workers and reformers within the Protestant mainstream based many of their criticisms as well as their solutions to the problems of industrialization upon their "notion of right." This perception was based upon both the republican political tradition and American Protestantism, in particular, the idea of Christian perfection, that man could live a sin-free existence. According to Clifton E. Olmstead, the doctrine of perfection increased steadily in American Evangelical Protestantism throughout and beyond the Civil War, flourishing in urban areas where the social problems and the individual frustrations presented a challenge to those who believed that Christianity could improve the present world. ${ }^{6}$ Trade unionists, reformers, and labor radicals, argues Gutman, suffered the brunt of the transition from a preindustrial to an industrial society and bore the social, economic and psychological brunt of the American industrializing process after 1860. Their religious beliefs, especially their adherence to the "timeless truths" of the Bible, served to sanction their criticisms against the existing industrial order and calls for reform. Henceforth, the quest for holiness became the "plain man's transcendentalism," ${ }^{7}$ a quest that would lead them out of the middle class churches of American Protestantism. Industrialization created new proletarian ideas regarding work, labor unions, and religion that set workers on a collision course with the middle and upper classes. ${ }^{8}$

\footnotetext{
${ }^{5}$ William G. McLoughlin, Revivals, Awakenings, and Reform: An Essay on Religion and Social Change in America, 1607-1977 (Chicago and London: The University of Chicago Press, 1978), 145-149.

${ }^{6}$ Gutman, "Protestantism and the American Labor Movement," 79.

${ }^{7}$ Timothy L. Smith, Revivalism and Social Reform: American Protestantism on the Eve of the Civil War (Baltimore and London: The John Hopkins University Press, 1980), 8.

${ }^{8}$ Gutman, "Protestantism and the American Labor Movement," 78-81, 97.
} 
The nation's rapid rise to industrial supremacy wreaked tremendous socioeconomic change, and Americans struggled to adapt. The most intense period of industrialization spanned a fifty year period that began during Reconstruction and ended as the United States experienced the devastating effects of the post-World War I recession. Four great labor conflicts were spawned during this period: the Great Railroad Strike of 1877; the Haymarket Affair of 1886; the Pullman Strike of 1894; and, the Great Steel Strike of 1919-1920. Protestants viewed the actions taken by the growing labor movement as threats to religion, government, and property rights, forcing middle class Protestants to become reactionary and militant to the point of hysteria. As Timothy $\mathrm{H}$. Kehl points out, these militant labor-conflicts shook the Protestant Mainstream when religious spokesmen began to question their previously firmly entrenched belief that America's economic progress was pre-destined and inevitable. ${ }^{9}$ In each event, the secular and religious press placed the blame for labor's troubles on the workers, not industry, declaring that immigration, urbanization, and industrialization were breaking down the character of the working class, endangering the long-honored traits of individualism and frugality. Both the secular and religious presses played a pivotal role in declaring that the working class was nothing more than a bunch of "wild animals" and “communists." 10

With their optimism shaken, clerics and their flocks decided that something had to be done to preserve the American way of life and to ensure continued economic progress. As the Gilded Age came to a close, the Christian social movement had a great deal of influence on American thought during the period. Followers of the Christian social

\footnotetext{
${ }^{9}$ Timothy H. Kehl, “The Protestant Church and the Labor Movement, 1877-1920” (Masters thesis, Chicago Theological Seminary, June 1973), 5-7.

${ }^{10}$ Kehl, "The Protestant Church and the Labor Movement," 5-7.
} 
movement hoped to stop the flow of blood and radicalism that threatened to rend the fabric of American society forever. ${ }^{11}$ The most prominent was the Social Gospel movement.

Most of the religious labor scholarship has traditionally been linked to the Social Gospel, a movement that emerged during the 1880s as Americans became increasingly disenchanted with Social Darwinism and laissez-faire economic policy. The movement's members were primarily from the middle class and members of mainstream Protestantism who were alarmed at the working and living conditions found in most industrial cities and the increasingly violent confrontations between workers and capital. Followers of the Social Gospel Movement hoped that improving the living and working condition of the poor would mean a return to order, and ultimately, the establishment of the Kingdom of God on earth. ${ }^{12}$

However, leaders within the Social Gospel Movement did not come from the movement's primary target of reform, the working class. Reformers declared the working class, which was primarily comprised of unskilled, illiterate, non-English speaking immigrants, was unfit to participate in the re-establishment of order and a danger to the American way of life. Instead, middle class ministers and their churches from the Protestant mainstream led the way. These ministers lamented the declining number of workers who attended their churches and the skyrocketing number of Catholics moving into their towns and cities. Ministers and theologians such as Professor Frances Greenwald Peabody saw the industrial problem, in particular, labor unrest, as

\footnotetext{
${ }^{11}$ Henry F. May, Protestant Churches and Industrial America (New York: Harper \& Brothers, 1949), 172175.

${ }^{12}$ Robert Moats Miller, American Protestantism and Social Issues, 1919-1939 (Chapel Hill: The University Press of North Carolina Press, 1958), 12-13.
} 
"the penalty" that the American public was paying for "not being Christian." Peabody, in his 1904 book "The People” in Organized Labor and Capital, declared that, "outwardly,” the problem appeared to be economic, legislative, and educational in nature, but in its essence, it was an "ethical, spiritual, religious" problem that called for "moral redemption." ${ }^{13}$

Reverend Craig Thoms echoed Peabody's concerns when he published The Working Man's Christ in 1912. In it, the theologian declared that the employer-employee relationship was a religious and ethical one, because ethical democracy was the "basic foundation of human society.” Furthermore, he warned that since the very existence of the church depended upon the righteousness of the individual and Christian brotherhood, it was imperative that the church address society's problems. Peabody believed that the number of unoccupied pews present in many churches was indicative of the church's failure to do its part to "secure righteousness and produce brotherhood." The theologian was clearly concerned with the spiritual condition of the American church. ${ }^{14}$

As the number of non-Protestant immigrants living in urban areas increased, Americans increasingly grew alarmed over the threat that this posed to traditional, American values. Clergymen declared that it was the duty of the church, especially those who were well-educated and prosperous, to work for reform and set a good example for the largely immigrant, working class. In spite of their efforts, middle class churches had little success in attracting the urban, working class to their congregations. Workers felt out of place, sitting among well educated, affluent people, who sympathized with their

\footnotetext{
${ }^{13}$ Frances Greenwood Peabody, Organized Labor and Capital: The William L. Bull Lectures for the Year 1904 (Philadelphia: G.W. Jacobs and Company, 1904), 221-223.
} 
plight but could never empathize with the hardships endured by the men and women who toiled in the mines, mills, and factories. At the same time, the presence of company owners and managers only increased the widening chasm between the working class and mainstream Protestantism. ${ }^{15}$

Thus, as the nation evolved into an industrialized, more urbanized society, the vast majority of its citizens failed to enjoy the fruits of prosperity, and the nation became wracked with industrial strife. During the Progressive Era, American society responded to “conflicting impulses” as both industrialists and skilled workers struggled for control of the shop floor and their share of the fruit of their labors. Workers, ministers such as Charles Stelzle, a Presbyterian minister and card-carrying union man, and the American Federation of Labor (AFL) perceived the "the labor question" as the most critical issue to face the nation, one that threatened its stability and continued prosperity. Most importantly, it was an issue of social and economic justice. ${ }^{16}$ Inspired by Stelzle’s Men and Religion Forward Movement, the AFL instituted the Labor Forward Movement as a way to bring social and economic justice to the working class poor and drum up support for the fledgling union. Drawing from strategies used by evangelists during revivalist campaigns, unions attempted to recruit the unorganized worker into its ranks, rekindle the enthusiasm and involvement of its membership, gain the support of the middle class, and enable unions to become a respected part of the reform movement. ${ }^{17}$

\footnotetext{
${ }^{15}$ May, Protestant Churches, 119-121.

${ }^{16}$ Elizabeth and Ken Fones-Wolf, "Trade-Union Evangelism: Religion and the AFL in the Labor Forward Movement, 1912,” Working-Class America: Essays on Labor, Community, and American Society, ed. Michael H. Frisch and Daniel J. Walkowitz, (Urbana: University of Illinois Press, 1983), 155-156.

${ }^{17}$ Ken Fones-Wolf, "Revivalism and Craft Unionism in the Progressive Era: The Syracuse and Auburn Labor Forward Movements of 1913” New York History 63 (October 1982): 390-391.
} 
Unlike capitalists such as Andrew Carnegie or J.P. Morgan, Charles Stelzle believed that the working class would win the war for industrial democracy. The church's lack of interest in the suffering and oppression that workers experienced at the hands of their wealthy employers caused workers to turn their backs upon the church once they were victorious. This was already the case. Like many proponents of the Social Gospel, Stelzle was highly critical of the majority of ministers who were totally unaware of the mass's working and living conditions. As a result of their indifference, churches, especially in the nation's rapidly growing industrial cities, were failing to maintain, much less increase membership. Stelzle was superintendent of the Department of Church and Labor in the Presbyterian Church and frequent delegate to AFL conventions. In 1911, he warned the Presbyterian membership that unless the church sought to institutionalize the natural relationship between itself and organized labor, one established by Jesus Christ Himself, the labor movement, with its strong religious spirit, would emerge as an alternative to organized religion. ${ }^{18}$

The Labor Forward Movement began in 1911 under the auspices of the ecumenical Federal Council of Churches. Stelzle hoped to plant a desire to address the social, economic, and moral issues confronting the poor and oppressed in the hearts of the middle class who occupied most of the pews in churches across the nation. Utilizing a blend of mass-appeal evangelism and the spirit of Progressive reform, the movement used eight-day campaigns that featured nationally prominent teams of organizers, termed social evangelists, such as Jane Addams and Booker T. Washington. They preached in mass meetings and organized parades to attract the public's attention. Smaller meetings

\footnotetext{
${ }^{18}$ Charles Stelzle, The Church and the Labor Movement, (Philadelphia: American Baptist Publication Society, 1911), 24-25.
} 
and house-to-house visits were also used to draw in special interest groups and individuals. Stelzle realized, however, that for the Men and Religion Forward campaign to garner the assistance of organized labor, it would have to do more for workers. Thus, like Roosevelt, he urged a "square deal” for labor, hoping that improved relations between workers and the churches would encourage members of the working class to repentance and to join the church. Stelzle also advised evangelists to educate the public on the ethical and moral value of union organizations. Stelzle argued that benefits such as strike funds, retirement, and sick benefits, and social and educational activities encouraged self-reliance. In addition, unions helped Americanize immigrants and create a climate for morality, pointing to AFL President Samuel Gompers’ plea for morality and sobriety. However, Stelzle endorsed collective bargaining, better wages and hours, and protective legislation aimed at women and children. Nevertheless, he discouraged changing America's system of production and organized labor's use of strikes and boycotts. ${ }^{19}$

Stelzle's limited view of what was considered acceptable labor activity during a labor conflict was not unlike that espoused by Gompers and the Federation by the early 1900s. The craftsman's desire for self-improvement, acceptance, and respect meant that the Federation increasingly called for strikes and boycotts only as a last resort and was less inclined to "stir up trouble for peaceably inclined workingmen.,"20

John Mitchell, president of the United Mine Workers of America, and Peter Brady, an organizer for the AFL, recognized the potential for using the movement to

\footnotetext{
${ }^{19}$ Elizabeth and Ken Fones-Wolf, “Trade-Union Evangelism,” 156; Stelzle, The Church and Labor Movement, 10-12.

${ }^{20}$ An Open Letter to Ministers of the Gospel (Washington, D.C.: The American Federation of Labor, n.d), 6.
} 
attract new members, revitalize the labor movement, and educate consumers to the plight of workers. Mitchell and Brady, who both participated in the Social Gospel revivals, envisioned a labor movement based upon the Religion Forward movement as a means to an end, one that would advance the interests of organized labor and improve its image. It was Tom Hamlin, however, a labor editor in Minneapolis, who first proposed a Labor Forward movement, one that would be based upon evangelism and craft-union culture. Hamlin realized that combining the genuine religious enthusiasm of people, regardless of their class, with the elements of camp meeting revivals could be used to bolster membership and support for trade unionism.

In April 1912, the Minneapolis Labor Assembly set aside two weeks in April which were centered around educating the public on the benefits of labor organization to both workers and the community. On April 21 labor spokesmen occupied twenty-one pulpits in churches throughout the city preaching "the true doctrine of trade unionism". The campaign spread to nearby St. Paul and continued into early May. Mass meetings were held to acquaint workers of all trades with the benefits of union organization as well as smaller meetings that targeted specific crafts. Business and professional groups also endorsed labor's call for better wages and working conditions. As a result, six unions were organized, and the membership rolls of existing craft unions swelled with new members. ${ }^{21}$

The Federation Executive Council discussed the Minnesota revivals at its May and August meetings and developed a plan to extend the campaign across the nation. Samuel Gompers, who was not a particularly religious man, realized that revivalism could be used as an effective tool that workers would enthusiastically seize as an

\footnotetext{
${ }^{21}$ Elizabeth and Ken Fones-Wolf, “Trade-Union Evangelism,” 158-159.
} 
effective weapon in their fight with manufacturers. In particular, Gompers stressed the need to link trade unionism to the moral and religious values embraced by the mainstream if the union was to compete with the IWW and the Socialists for unorganized workers. Gompers envisioned Labor Forward as a way to use the ethical principles of religion to reassert the AFL's leadership, reinforce its ideals and hope for a better life for all working people within the capitalist system. ${ }^{22}$

The Council unveiled their plan in the October 1912, issue of the American Federationist. Members of the council had divided the country into eight districts and promised that teams of organizers would be sent out from the national and international organizations and the AFL. The state labor federations were responsible for initiating the campaign in their respective states and arousing enthusiasm for the movement. The Council suggested that central labor bodies in cities across the nation establish organization committees. These committees would be responsible for dividing each city into canvassing districts and planning revivals that would meet their particular needs. ${ }^{23}$ Besides sponsoring great revival-like meetings that included preaching by union evangelists and special music, other strategies used in the Labor Forward movement included the holding of craft balls, athletic events, smokers, picnics, parades, and trade bazaars, the selling of union buttons, talent shows, and pledge drives.

Between 1912 and 1916 trade unionists, Protestants, Catholics, and Jews, in more than 150 cities and towns across the nation participated in the Labor Forward Movement, exhorting sinners (the unorganized) to repent of their "sin" and sign a membership card in their local labor union. Their work represented the AFL's most ambitious effort to

\footnotetext{
${ }^{22}$ Fones-Wolf, “Trade-Union Evangelism,” 160-161.

${ }^{23}$ Samuel Gompers, “Editorial.” American Federationist (October 1912): 828-831.
} 
expand its membership rolls and sphere of influence. Hoping to organize workers and gain the support of the public, the AFL directed its various unions to hold conventions. Typically, union representatives and organizers of various labor organizations were on hand to address the crowd and give their suggestions on strategies that the unions could employ to organize the unorganized. Speakers often used religious rhetoric in their support of labor unions, called the shop floor "the chapel," and advised local leaders to use churches, schools, homes, and street corners as places to preach the union gospel. In addition, unionists were also urged to convince pastors to permit locals to hold meetings in their churches, to announce these meetings from the pulpit, and to send labor evangelists to address congregations on the benefits of union organization. The latter strategy would reach people who would not normally "go to meetings at union halls-men and women alike who would not be reached otherwise.”24

Labor assemblies also sent speakers to various business, professional, and religious organizations, in order to explain the objectives of the movement. In addition, individual assemblies participated in Child Labor Sundays to denounce the immoral use of children in the workplace. Assemblies also sponsored various social activities and political causes. Such activities suggest that it was a very family-oriented organization. However, there were more practical reasons for including activities that focused upon females. First, strikes and boycotts would have little chance to succeed unless organized labor could convince workers' wives of the need to give their full support to the activities of their husbands' unions even if it meant personal sacrifice, their labors were in vain. At one convention in Wheeling, a speaker suggested that union members first call upon a

\footnotetext{
${ }^{24}$ Ken Fones-Wolf, “Revivalism,” xiii; Elizabeth and Ken Fones-Wolf, “Trade-Union Evangelism,” 162-165.
} 
man's wife and persuade her to take a union card, believing that she had the power to force him carry it. Various unions issued special invitations to their members' wives and daughters to attend their open meetings and social activities. When the Wheeling Assembly held a mass meeting in 1915 in an effort to merge the feuding Cigar Makers and Stogie Makers and ensure the Ohio Valley's Trade and Labor Assembly's (OVTLA) entry into the AFL, Thomas Tracy of the International Cigar Makers’ Union addressed his appeal for support of the union label to the women. For as he argued, "after the rent is paid, which is one-fifth to one-fourth of the workers' income, the women of the family spend 90 percent of the income. Secondly, countless number of women worked in factories and shops across the nation. Consequently, the various conventions, meetings, social activities were also designed to spread the "gospel of trade unionism” among working women. ${ }^{25}$

By 1915, interest in the Labor Forward movement had begun to wane. Some unionists realized that as mechanization and the division of labor continued to reduce the number of skilled workers necessary for efficient production, it was only a matter of time before the era of the craft union would come to a close. What was needed was an industrial union that would unite workers regardless of their level of skill. The demographics of the industrial work force created a paradox for the American Federation of Labor. For at the same time the American Federation was working to increase its membership and sphere of influence, it was also trying to distance itself from the very same workers whose inclusion would ultimately be needed for its future success and survival. In addition, many modern industrialists were unmoved by the religious rhetoric of the labor evangelists and their pleadings for harmony in the community. Instead,

${ }^{25}$ Wheeling Majority, 15 January 1915. 
employers focused upon on improving their profit margins. Technology made it easy for employers to replace striking skilled craftsmen with unskilled laborers willing to work for cheaper wages. These workers, long ignored by the American Federation of Labor, would be attracted to groups such as the IWW, the Socialists, and industrial unions established under the umbrella of the CIO, organizations that were willing to fight to improve the lives of all workers. These challenges, and America's growing involvement in World War I finally brought the Labor Forward movement to a close in $1916 .{ }^{26}$

Organized labor's use of the elements of evangelical religion, its rhetoric, revival strategies, and the development of a close relationship between labor unions and preachers would be put on hold while the nation was involved in war. But evangelical ministers would once again take up the cross for the working man as the working class increasingly found themselves among the "have-nots" during the 1920s and the Great Depression. Once again, preachers would provide both the spiritual and economic answers to the question, “What must I do to be saved?” Under John L. Lewis, the United Mine Workers Union employed some of the same strategies formerly used in the Labor Forward movement in organizing drives across Appalachia. Movements such as the Labor Forward movement did not take place in the Eastern Kentucky coalfields. The American Federation of Labor was well represented in large cities with diversified economies in the central and bluegrass sections of Kentucky. As an association of craft unions, however, the Federation displayed only limited interest in bringing Harlan's miners into its fold until 1938. The movement did, however, have limited success in the coalfields of southern West Virginia. Hence, it should not be a surprise that organizers such as George Titler would follow a similar recipe in drumming up members as well as

${ }^{26}$ Elizabeth and Ken Fones-Wolf, “Trade-Union Evangelism,” 170-171. 
support for the United Mine Workers Union in District 19. Such strategies were even more appealing to the miners of rural Appalachia. By the 1920s, the old time religion and the emotional fervor of the camp meeting may have lost its appeal to those living in more urban areas, but the opposite was true in rural regions. Rural people continued to flock to camp meetings to hear the old-time religion and respond to calls for salvation. ${ }^{27}$ This was especially true in the coalfields of Appalachia where holiness-Pentecostal religion experienced the greatest growth. In Harlan County, the number of holiness-Pentecostal churches grew dramatically during this decade. By the time that the Battle of Evarts erupted in May 1931, holiness-Pentecostal churches were scattered throughout the county. And as their number grew, so did the membership of the United Mine Workers. In 1931, the towns of Ages, Harlan, Highsplint, and Twila were homes to both churches belonging to the Church of God (Cleveland) local unions of the United Mine Workers of America. The tiny town of Evarts, an independent, commercial town where the union maintained its headquarters, had two such churches located within its corporate limits, making it the heart of religious and labor radicalism. ${ }^{28}$

While many of the county's miners were saved from their sins, they were still waiting for a Savior who would rescue them from the throes of economic deprivation and oppression. Miners had been calling for John L. Lewis for more than a decade. Unfortunately, this particular prayer would remain unanswered until the passage of the passage of the National Industry Recovery Act, Section 7 (a), in June 1933. Initially, most workers believed that Section 7 (a), which guaranteed workers the right to join a

\footnotetext{
27 Bush, Bush. "Religious Fervor in the Fairmont Field: Calls for Revival and Reform in the 'Coal City,' 1908-1929.” < http://are.as.wvu.edu/cbush.htm> (14 July 2006)

${ }^{28}$ Michael P. Szpak, Unpublished paper, "The Church of God (Cleveland, Tennessee) and the Labor Movement, 1908-1925: A Research Update,” 1984.
} 
union of their choice and to bargain collectively, placed the federal government solidly on the side of organized labor. Unfortunately, unions would only enjoy a brief flirtation with success. As the opposition of employers increased, along with the spread of company unionism, and inadequate enforcement of the act, union membership, which had soared to dizzying heights, began to fall. In spite of this, the National Recovery Act temporarily proved to be labor’s "Magna Carta." For a brief moment, the Harlan miners thought that their prayers had been permanently answered as John L. Lewis seized the moment, borrowed some money, and directed his organizers to act quickly "before the employers woke up to the fact that there were ways of getting around the law." Everywhere in the nation's coal camps, organizers assured miners that "the president wants you to join the union." Miners were convinced that "the president" was none other than President Franklin D. Roosevelt after organizers spread a rumor that "John L. Lewis was having beer and sauerkraut with President Roosevelt every night.” Within weeks, the membership of the United Mine Workers Union had increased its membership by 500 percent. Even Lewis' most ardent foes were forced to acknowledge his victory. Old enemies, such as Oscar Ameringer, reluctantly admitted that "John turned out to be the only archangel among the angels with fallen arches of the A.F. of L. crowd" while John Brophy and Powers Hapgood declared that he was indeed "the man of the hour of the labor world."29

The scripture "The harvest field is white, but the workers are few" had a double significance for the miners of Harlan. ${ }^{30}$ During the 1920s, more and more miners and their families found comfort and salvation at the altars of holiness-Pentecostal churches.

\footnotetext{
${ }^{29}$ Hevener, Which Side Are You On? 94-96.

${ }^{30}$ John 4:35
} 
The working class theology that emanated from pulpits manned by their fellow miners convinced them that, with God, anything was possible, even the United Mine Workers of America in Bloody Harlan. Thus, by 1931, the miners were ready to throw off the shackles of quiescence and rise up in opposition against their oppressors. The harvest field was white in Harlan County, and the miners were waiting for their Savior, John L. Lewis, to free them from bondage. If John L. Lewis was the miner's savior in the northern coalfields of Illinois and Pennsylvania, then he would surely answer their prayers as well.

Initially, Lewis ignored their pleas. Under the pressure of operators in the Northern and Central Competitive Fields to organize Harlan or risk losing their support, the union sent organizers into the field in 1933. Unfortunately, the miners and the union realized only limited and temporary success, and by the summer of 1935, the operators association had successfully expelled the union. For the next two years, the HCCOA increased its iron grip upon the miners, their families, and their communities. Its hired guns and deputies built an impenetrable wall around the county. It would be up to the miners themselves to maintain the spark of hope that Section 7 (a) ignited. Under the cover of darkness and secrecy, the union faithful continued to preach the gospel of unionism and gain converts. Miner preachers continued to work as organizers, unbeknownst to the operators, and the union's ranks grew ever so slowly, one miner at a time, during the interim. More often than not, one man secretly took the oath without knowing if the miner who worked alongside him was friend or foe. Thus, the union was rebuilt, one man at a time, under the cover of darkness. Its members would not see the light of day until their savior arrived in the form of the federal government. 


\section{CHAPTER 4}

\section{THE ASCENDENCY OF KING COAL AND THE COAL KINGDOMS OF BENHAM, LYNCH}

As engineers and work crews poured into eastern Kentucky to construct the Louisville and Nashville Railroad in the first decade of the twentieth century, they encountered a people whose lives had changed very little since the earliest days of settlement. The Samuel Hoard family established the first settlement in the territory in 1794. The Hoards and those who followed them certainly had their work cut out for them. Rugged mountains with steep sides rise from a narrow, valley floor. The land, which was then part of Floyd and Knox counties, was under the dense cover of virgin forest. In spite of such obstacles, these first settlers persevered and went about the work of clearing land for small farms, building log houses, and surveying and building roads. ${ }^{1}$

Little had changed in Harlan County for the descendents of the county's first settlers. In the summer of 1888, New York journalist Charles Dudley Warner visited Harlan. In his journey along the Wilderness Road, Warner witnessed a beautiful landscape of "great trees...frequent sparkling streams, and lovely mountain views.” In spite of such great beauty, Warner found the mountain roads to be little more than rough, rocky trails, lined with “occasional poor shanties” and "rugged little farms.”2

The harsh terrain and climate limited settlers' access to the outside world, and determined that subsistence farming would be the center of the economy. Until the

\footnotetext{
${ }^{1}$ John A. Dotson, "Socio-Economic Background and Changing Education in Harlan County, Kentucky" (Ph.D., diss., George Peabody College for Teachers, June 1943), 8-10.

${ }^{2}$ Ronald D. Eller, Miners, Millhands, and Mountaineers: Industrialization of the Appalachian South, 1880 1930 (Knoxville: The University of Tennessee Press, 1982), 39-40.
} 
coming of the railroad in 1910, the county remained nearly isolated. A few dirt roads had been built to Hagan, Virginia, and to Pineville, providing teamsters with routes in which to collect produce at the country stores and return with supplies that could not be produced on the farm. Farmers drove their hogs to markets in Lynchburg, Virginia, and Lexington, Kentucky, and cattle and sheep buyers came into the county, purchased their stock, and drove them out to market. The forests produced an abundance of black walnut trees which were turned into fence posts or logs for the construction of homes. In time, most of the trees harvested made their way to the outside world, making timbering the county's first industry. ${ }^{3}$ Such limited economic diversity made it possible for farm families to adequately support themselves, but only those families who owned the county's limited supply of rich, bottom land realized any true wealth. The county's wealth lay deep, under its mountains and high upon its ridges. In time, its vast supplies of timber, iron ore, and coal would bring prosperity to the mountains. Coal, however, would bring the county its greatest wealth and the attention of the nation. The coming of King Coal would permanently change the cultural and physical landscape of the county.

The county's citizens had not been blind to the progress occurring around them. They watched as the timber and coal industries were developed in nearby southern West Virginia, bringing with them the fruits of progress in the form of railroads, employment opportunities, a proliferation of small businesses, new schools, and improved health care. The people watched as railroads began to stretch across the nation like a giant spider web, railroads that linked rural folks to city dwellers and made economic progress possible. In 1894, Herbert Carleton of the Eastern Kentucky News wrote about the poverty and dreams of the citizens of Harlan: "To a stranger, coming as I have from a rich and

\footnotetext{
${ }^{3}$ Dotson, “Socio-Economic Background,” 15-16.
} 
populous part of the country to Harlan County, the poverty is plainly evident. This impression becomes intensified when I contrast the wonderful wealth of mineral and lumber resources and latent steam and water power unused. Several men have said to me that all that is needed to develop marvelous wealth in this county is to have some Northerners come to settle here or to have capitalists put a railroad through the county.” Carleton shared their hopes, dreams, and visions, but only to an extent. He believed that “another way is better, namely for the sturdy citizens who can cultivate corn on hillsides so steep that a Northerner would pitch off, for these people who are as bright by nature as any American, to take up those local opportunities and develop this wealth themselves.”4 Local talent and capital initiated the industrial expansion, but full-scale development of the timber and coal industries would require the importation of great infusions of capital. In 1870, Edward M. Davis, of Philadelphia purchased a patent which was known as the "Blanket Survey” of Ledford, Skidmore, and Smith, consisting of an 86,000 acre grant in Bell and Harlan Counties. Twenty years after Davis’ purchase, T.J. Asher and Robert Creech, of Pineville, began buying timberland along the Cumberland River and its branches. Within a decade, Asher and Creech had amassed several thousands of acres and initiated the logging industry. Much of the available timber was harvested during the decade with little need for outside labor, and the county's population and culture remained much as before. In 1902, signs of change were on the horizon when trustees of the Edward M. Davis estate had the United States Geological Survey and the Kentucky State Geological Survey conduct a survey of the Cumberland River Valley region. At the time of the survey, more than five thousand people lived in a region, buried with over 18,000 conflicting patents, deeds, and possessions. When the survey

\footnotetext{
${ }^{4}$ Dotson, “Socio-Economic Background,” 20-22.
} 
was finished, the Davis Estate organized the Kentenia Corporation as a holding company and cleared up the titles between 1904 and 1907. Between then and 1910, the company consolidated approximately one hundred square miles of land. When the geological survey was published in 1904, other capitalists came into the county and bought coal properties as well. ${ }^{5}$

Initially, most of the native whites preferred to remain on the farm and did not seek employment as railroad, timber, or mine workers much later. An employment scarcity threatened further expansion of the fledgling industries. Thus, when the full scale development of the county's rail lines called for a larger work force than the local populace could provide, coal operators hired labor agents to recruit workers from far and wide. Immigrants began arriving from Europe in large numbers in 1908 to participate in the construction of the Louisville and Nashville Railroad. Most important to the railroad were the Italian stonemasons who constructed bridge foundations and culverts from native limestone. After the tracks were laid, many immigrants chose to remain in Harlan and work as miners or stonemasons. ${ }^{6}$

With the coming of the Louisville and Nashville Railroad in 1910, economic development commenced at a dizzying rate. Within three years, the hillsides had been stripped of vegetation, and electrified spurs, tipples, shacks, and stores converted farm hollows and wilderness into mining camps. Investors and operators surely celebrated, when, on the third year of production, the county's mines produced a landmark million

\footnotetext{
${ }^{5}$ Dotson, “Socio-Economic Background,” 21.

${ }^{6}$ Doug Cantrell, Immigrants and Community in Harlan County, 1910-1930," Register of the Kentucky Historical Society 86.2 (1988): 121-122.
} 
tons of coal. ${ }^{7}$ The demand for immigrant labor escalated when capitalists began to develop their mines. Labor agents were dispatched to the northern port cities of New York, Boston, Chicago, and Philadelphia to recruit workers from the large immigrant communities that lay within their boundaries. Using interpreters, the agents promised immigrants, most of which had just arrived in America, high wages and steady work in the mines. Agents tagged and placed those who agreed to accept employment on a train destined for one of the county's many coal camps. Coal operators used the padrone system to obtain immigrant labor. A system that had been in use in all major northern cities, the padrone system revolved around the use of an intermediary to recruit new arrivals. In return, employers paid the padrone a set fee for obtaining the required number of workers. In most cases, the padrone was an immigrant who had been in the country long enough to acquire American ways and speak English. With an air of confidence and wearing a well-made suit, the padrone greeted immigrants who hailed from his place of birth at the dock. He offered them a place to stay and agreed to help them find employment. The padrones exploited immigrants by contracting with mine owners to supply them with cheap labor. The system was known as "on transportation" throughout the southern coalfields and was the most effective method for securing foreign-born labor. In the end, the padrone system did not cost the mine owners a cent since both the padrone's fee and the cost of train fare were deducted from the new miner's pay envelope. Companies also advertised in eastern newspapers, especially the foreign-language press. Other immigrants came on their own, at the advice of friends or relatives who were already living in Harlan. Usually, the relative or friend wrote a letter

\footnotetext{
${ }^{7}$ Dotson, “Socio-Economic Background,” 23; Kelemen, “A History of Lynch, Kentucky, 1917-1939” (Ph.D,, diss., University of Kentucky, 1972), 33.
} 
to a potential worker back home. If he agreed to come to Harlan, the contact spoke to the personnel agent at the mine where he was employed and secured employment. Immigrants, unable to speak English and with little money left in their pockets, were more than happy to accompany the padrone to the train station, where he would purchase their fares and send them on their way, to the promise land. They were willing to work hard at any job that would help them realize the American dream. Within weeks, the new miner arrived in Benham or Lynch. ${ }^{8}$

Coal strikes in the coalfields of Pennsylvania, Ohio, and West Virginia frequently lured immigrants to Harlan County as well. Usually, the immigrants were "birds of passage” who were only interested in remaining in America long enough to earn enough money to return home and purchase a farm. As a result, they were usually young, single men, who saw little need for unionization. Consequently, if their fellow miners went on strike, they left to seek employment elsewhere. By 1910, the United Mine Workers had organized the coalfields of Pennsylvania and Ohio. The union then turned to West Virginia where the conflict escalated in the post war period. Thus, while operators in West Virginia had their hands full, dealing with strikes during the 1920s, eastern Kentucky was relatively calm. It is no wonder that Harlan's operators especially valued these men.

The construction of their mining operations were not even complete when operators began sending recruiters far and wide in order to recruit the thousands of men needed to extract the black diamonds that lay deep under the county's mountains. Soon, men were flocking to Harlan, from nearby Letcher and Bell Counties and the neighboring states of West Virginia, Virginia, and Tennessee, to the industrial city of Birmingham,

\footnotetext{
${ }^{8}$ Cantrell, “Immigrants and Community,” 122-124.
} 
Alabama in the Deep South, and as far north as Pennsylvania. As soon as the houses were finished, miners and their families arrived, eager to settle in and enjoy the fruits of the Promise Land. Harlan was “a wholecloth of development by outside capital.” New money built homes, schools, and churches, paved the roads, hired the police, and paid wages to men who, for the most part, had been farmers or field hands. Author Malcolm Ross said it best when he said that, for the most part, the miners were "country people who exchanged the sunlight for the dark of a mine shaft." ${ }^{\text {9 }}$

Regardless of their origins, the miners viewed the exchange as a favorable one. For most, regardless of their race, ethnicity, or national origin, coal mining was the only available way out of a life of poverty and deprivation. From 1920-1930, when surrounding counties were losing population to out-migration, Harlan increased its population by 65 percent. The number of miners working in the county peaked in 1930 when approximately 12,000 men were working in its coal mines. These men made up 25 percent of the labor force for all of eastern Kentucky. ${ }^{10}$ The streets were not paved with gold, but to the vast majority of its newcomers, the road into Harlan County was surely the road to prosperity.

Harlan’s coal industry expanded rapidly because of three factors: high quality coal that had a low sulphur and ash content; the absence of unionism which provided coal operators with uninterrupted production, a lower wage scale, and nonunion work rules; and, until 1929, a more favorable freight rate structure. Since Harlan’s drift mines offered all of these advantages, the field expanded rapidly. The largest operations were captive mines whose entire output was utilized by the parent company's manufacturing or

\footnotetext{
${ }^{9}$ Dotson, “Socio-Economic Background,” 24.

${ }^{10}$ Philip Tankel, “'Bloody’ Harlan 1931-1938: An Appalachian Coal County in the Thirties,” (Honors Thesis, Brandeis University, 1968), 9.
} 
power-generation plants. As a result, captive mines such as those owned by International Harvester, U.S. Steel, and Ford produced about three-eighths of Harlan's total output. In order to attract and maintain their work force and production, International Harvester and U.S. Steel constructed the model company towns of Benham and Lynch whose mines employed the majority of black miners and were the last to unionize.

By 1921 Harlan had become the top coal-producing county in Kentucky, and the company towns of Benham and Lynch were the jewels in its crown. Increased demand for products such as steel I beams, automobiles, tractors, and electrical appliances put American manufacturers on the lookout for quality coking coal that could be produced without interruption and at minimal costs. The need to establish captive mines whose entire production would be sent straight to steel production facilities translated into the construction of well-planned, model towns designed around the "total systems approach.” Such an approach was designed to address the four most important concerns of operators directed to maximize production and minimize costs: alcoholism, strikes, worker turnover, and safety.

For corporate giants such as United States Steel, International Harvester, and Ford Motor Company, the search ended in Harlan County, Kentucky. U.S. Steel and International Harvester Wisconsin Steel Company (International Harvester’s subsidiary at Benham) and U.S. Coal \& Coke Corporation (U.S. Steel's subsidiary at Lynch.) located their captive mines along the banks of Looney Creek. Wisconsin Steel, a subsidiary of International Harvester, and U.S. Coal and Coke, a subsidiary of U.S. Steel aimed to create model communities in the company towns of Benham and Lynch. Towns such as these were designed to create workers whose identities and loyalties were tied to their 
employer. With this in mind, tools in the employee recruitment kit included well-built houses with electricity, water, and sewage; shopping facilities, doctors, dentists, and hospitals, paved roads, recreational facilities, quality schools, and churches. U.S. Steel and International Harvester were determined to keep the union out of Lynch and Benham and the production of coal flowing at any cost. For more than a decade, they succeeded. $^{11}$

International Harvester was the first to construct a model town in the county. In 1900, the Deere Harvester Company (which would later be known as International Harvester) built a steel mill in South Chicago and set up its coal mining operations at Benham to provide a steady flow of coal at reasonable prices. The steel mill was completed in 1908 and operated by its subsidiary, Wisconsin Steel Company. Two years later, the company erected their sawmill next to Looney Creek, in order to harvest virgin timber from Black Mountain. This timber would be turned into lumber for the construction of Benham. The Louisville and Nashville Railroad extended a spur from Pineville to Benham, and in September 1911, the first coal shipment departed Benham for Chicago. By November 1912, 300 coke ovens had been completed, along with 175 houses, three churches, a school, and a Y.M.C.A. building. In time, 520 company-owned houses lined the streets of the new town. ${ }^{12}$

U.S. Steel built the town of Lynch in 1917 after the company purchased forty thousand acres at the head of Looney Creek to begin its mining operations. Its subsidiary, United States Coal and Coke, began the construction of the town and opened a mine shaft in August of the same year to provide coal for U.S. Steel's mills in Gary,

\footnotetext{
${ }^{11}$ Wagner and Obermiller, African American Miners and Migrants, 68-90.

${ }^{12}$ Wagner and Obermiller, African American Miners and Migrants, 68-69.
} 
Indiana. The town, named after Thomas Lynch, the first president of the U.S. Coal and Coke Company, took eight years to complete, but it was worth the wait. When the mine commenced operation, it was the first, fully electrified mine in the country. Its power plant generated electricity for the mine’s lights, cutting machines, and narrow-gauge underground railroad. February 12, 1923 was a "blue ribbon day" for the company and its employees as the mine broke the old world record for daily output in a single day when its work force produced 7,089 tons. ${ }^{13}$ Memphis Tennessee Garrison, a black welfare worker in U.S. Steel's mining operations in West Virginia noted that by this time, "U.S. Steel had the best houses; they had the safest mines. They had the most modern mining machinery and they set the pace."14

While both U.S. Coal \& Coke and International Harvester set out to provide pleasant communities for their work forces, with the goal of attracting "good men and keeping them” as company employees, U.S. Steel's effort was described as "bending every resource of large capital and the trained intelligence which money can buy to the making of a modern town.” By the 1920s, Wagner and Obermiller state that both towns were thriving and competing with each other for workers, on athletic fields, and in matters of community pride. Such competition benefited employees and their families in the form of quality schools, recreational facilities, and health care that miners in only a handful of company towns enjoyed. Against the wishes of his mother, Charles Gregory moved to Benham in 1921 after being discharged from the Army. He was "surprised" to find everything found in "any other ordinary small town" and soon obtained employment

\footnotetext{
${ }^{13}$ Harry Caudill, Night Comes to the Cumberlands: A Biography of a Depressed Area (Boston and Toronto: Little, Brown, and Company, 1963), 99-102.

${ }^{14}$ Caudill, Theirs Be the Power, 99-102; Wagner and Obermiller, African American Migrants and Miners, 69.
} 
in the Y.M.C.A., where he worked until he went underground to work as a coal loader. ${ }^{15}$ In spite of its numerous benefits, Lynch was no “ordinary small town.” Just as mines owned by International Harvester and Ford prospered, so did U.S. Steel's operations at Lynch. Miners and their families realized a quality of life few could have attained before the arrival of King Coal. However, working for U.S. Steel and living in Lynch was different than it was elsewhere in the county. Outsiders made up most of the work force in Lynch, and the company made sure that its workers lived in "semi-isolation.”"16

Operators such as U.S. Steel hoped that its churches would help create good workers and good citizens and a peaceful, orderly community, but they had no intention of encouraging any type of bonding among its citizens. In order to thwart the formation of working class consciousness, U.S. Steel employed a judicious mixture when recruiting their workers. Initially, the majority of outside workers were native-born Americans recruited from the local area, but underground miners were mostly "foreign-born and colored.” In 1926, one magazine called Lynch “the new melting pot” and estimated that approximately 25 percent of the city’s population was comprised of American born whites. Southern Blacks and Eastern European immigrants made up the rest of the population. ${ }^{17}$

By 1920, the population of the county tripled. Where the population had been less than 11,000 in 1910, it had grown to more than 31,000. The growth of the immigrant population was especially striking. In 1910, the total number of immigrants living in Harlan County was twelve, but by 1920, their numbers had swelled to more than 1,200.

\footnotetext{
${ }^{15}$ Wagner and Obermiller, African American Migrants and Miners, 71-72; telephone conversation with Naomi Wooten, July 2005.

${ }^{16}$ Thomas A. Kelemen, “A History of Lynch, Kentucky, 1917-1930” (Ph.D., diss., University of Kentucky, 1972), 40.

${ }^{17}$ Wagner and Obermiller, African American Migrants and Miners, 73.
} 
Southern and eastern European immigrants comprised the largest portion of the population, as they did in the United States as a whole. They came to America looking for economic opportunity, something that was in short supply in southern and eastern Europe at the turn of the $20^{\text {th }}$ century. Charles Luchok had been a farmer in his hometown of Mukachevo, Hungary. When he and his young wife realized that remaining in Hungary held very little promise, Charles left his wife and young son behind with her parents and migrated to America in 1903. He soon obtained work in a sugar refinery in Brooklyn. Looking for better wages and opportunity, Charles moved to the anthracite coalfields in northeastern Pennsylvania where he found work in the mines. After ten years of labor, he had saved enough money to buy passage for his wife and son to join him in America. Like most immigrant miners, the Luchok family did not hesitate to move to more lucrative fields, and in 1922, they relocated to the Scotts Run field in north central West Virginia. Others found their way to Harlan County, Kentucky. ${ }^{18}$ In 1920 , Hungarians (320) made up the largest ethnic group, followed by Italians (233), Yugoslavians (145), and Poles (100). The following groups had less than 100 members each: Mexicans, Russians, Austrians, Czechoslovakians, Germans, English, Greeks and Syrians. Only eight Canadians and eight Irish immigrants resided in the county while the total number of French, Romanians, Scots, Welsh, and Swedes only equaled twenty-nine. Only one Dutchman had immigrated to Harlan. The $14^{\text {th }}$ Census indicated that 47 immigrants of unknown nationality were also making their home in the county in $1920 .{ }^{19}$

\footnotetext{
${ }^{18}$ Ronald L. Lewis, “Americanizing Immigrant Coal Miners in Northern West Virginia: Monongalia County Between the Two World Wars" in Transnational West Virginia: Ethnic Communities and Economic Change, 1840-1940, ed. Ken Fones-Wolf and Ronald L. Lewis (Morgantown: West Virginia University Press, 2002), 265-266.

${ }^{19}$ Cantrell, "Immigrants and Community,” 125-126.
} 
The composition of the immigrant population changed between 1920 and 1927. In 1924, the Italians became the largest ethic group employed in the county’s mines. Three years later, the immigrant population had only slightly grown, with 1,383 foreignborn men, women, and children living in Harlan County. ${ }^{20}$ Their transition to industrial life in America was similar to immigrants settling elsewhere: they developed new institutions and retained old ones. The boarding boss system was their attempt to recreate the extended family in the coal camps. Similar to the boarding house system found in cities throughout the Northeast, married immigrants took boarders into their companyowned houses to earn extra money. While the husband was called "the boarding boss," his wife did the work for the entire, "extended family," a family that typically included the couple and their eight-to-twelve boarders. She cooked, washed clothes, cleaned, and kept house for a family that could include as many as twenty or more persons if the couple had children. The men paid the boarding boss between four and five dollars per month, an amount that usually far exceeded the wages that he earned in the mine. ${ }^{21}$ Mining camps were segregated, both ethnically and racially. Although such divisions had been determined by the operators, these communities, frequently referred to as “Tallie Hollers,” "Little Polands,” "Hunkievilles,” and “Niggertowns,” served as extended families that helped one another in times of need. Equal in importance was their function in preserving their culture. While the men gathered to make wine, their wives cooked and baked traditional foods for holidays, weddings, and other special occasions. Almost every ethnic group had its own lodge. In Lynch, the Hungarians, Italians, Poles, Russians, Croatians, and Austrians each had a club. These organizations

\footnotetext{
${ }^{20}$ Cantrell, "Immigrants and Community,” 126.

${ }^{21}$ Cantrell, "Immigrants and Community," 127.
} 
sponsored dances, concerts, fairs, held sales to raise money, and conducted funerals for their members. These clubs contributed to the preservation of each group's culture and the community's social life, but they primarily existed for the mutual protection of their members. Members paid monthly dues in return for a form of insurance. When a member was injured or killed as the result of an accident, he or his heirs were compensated. While they functioned in much of the same way as those found in northern cities, they were especially important in coal camps since coal companies paid the victims of mining accidents very little, if any at all. ${ }^{22}$

Prejudice existed underground as well. In most mines, an ethnic job hierarchy placed the well-paying jobs out of the reach of immigrant miners. Before mechanization, all miners started out as pick miners. However, immigrants were more than likely to remain pick miners while native whites were promoted to management and company jobs. Immigrants and blacks were usually stuck with the most dangerous and physically demanding jobs in the mines: digging and hand loading coal; blasting at the coal's face; and working around the coke ovens. There were, however, exceptions.

A few immigrants were able to advance into management. This was especially true of U.S. Coal and Coke's mines at Lynch which employed most of the county's 822 remaining immigrants in $1930 .{ }^{23}$ Hoping to increase production and profits, the company promoted a few immigrants to management positions. Since many foreigners could not understand English, operators divided their work crews according to nationality. For example, Polish miners were assigned to one area of the mine with a Polish foreman while Hungarian miners worked in another part of the mine under the supervision of a

\footnotetext{
${ }^{22}$ Cantrell, "Immigrants and Community,” 132-133.

${ }^{23}$ John Hevener, Which Side Are You On? The Harlan County Coal Miners, 1931-1939 (Urbana and Chicago: University of Illinois Press, 2002), 4.
} 
Hungarian foreman. Thus, operators could ensure that their miners understood safety and work instructions. They also posted work orders and safety rules in various languages at the mine face and in the lamp houses. In doing so, operators could make sure that the company’s motto, “Safety, the First Consideration,” was practiced at all of their mines. ${ }^{24}$ Ignatz Bosch was one of the Hungarian miners promoted to the position of foreman at Lynch. Born in 1884, Ignatz was born in Ufuala to a family of farmers. Ignatz, along with his wife, and children, immigrated to America by steamship from the Port of Hamburg, Germany in the spring of 1907. They arrived in New York Harbor on May 11, 1907. After they were processed at Ellis Island, the family first traveled first to Buffalo, New York. Evidently unable to find permanent employment, they moved to South Bend Indiana, where Bosch found permanent work with Oliver Plow, a farm implement manufacturer. The company paid him sixteen cents an hour, but he had high hopes for his family's future. Upon learning that he could earn two dollars per day, working as a coal miner, the family once again packed up their belongings and headed for Welch and Gary, West Virginia. Ignatz evidently established himself as a good worker for U.S. Coal and Coke, because the company transferred him to Lynch to work in their new mines there in 1917. Ignatz, his wife, three children, their four boarders, household furniture, and livestock traveled to eastern Kentucky, all in one box car. Ingatz was one of the original miners at the Lynch mines. Like most immigrants during this period, he and his wife were eager to prosper and become good, productive American citizens. They both learned to speak English, and Ignatz became a naturalized citizen in 1925 and his wife received her citizenship papers in 1945. Prior to becoming an American citizen, Bosch had become a certified mine foreman. In 1922, he took and passed the foreman's

${ }^{24}$ Cantrell, “Immigrants and Community,” 138-139. 
examination and was awarded his Mine Foreman’s Papers by the Kentucky State Bureau of Mines and Minerals. Ingatz Bosch worked underground for more than forty years as a section foreman at Mine 31, B seam, where he supervised a section of miners that usually consisted of non-English speaking Hungarians and a few Black miners. His son Bill remembers miners coming to their home to collect their pay statements. Usually, his father was asleep, so his children followed his instructions and gave the men their statements when they came to the door.

Ingatz became very involved in his community. Popular in both immigrant and native circles, he was instrumental in helping other Hungarian families settle and adjust to life and work in a coal mining community. He participated in the fraternal and social life of the Hungarian-American community and helped to establish a lodge for the Woodmen of the World Life Insurance Society, an organization that sponsored many ethnic social activities. The Bosch family attended the Church of the Resurrection Catholic Church in Lynch. ${ }^{25}$

The most important institution in the community was the church, and for most immigrants, this was the most important institution that they would recreate in their new home. In Harlan County, two of the most prominent institutions were the Roman Catholic and Greek Orthodox churches. Before 1910, native whites made up the majority of Harlan's population and were almost exclusively Protestant, with Baptists being the predominant denomination. During the next two decades, the reverse would be true, and

\footnotetext{
${ }^{25}$ Bill Bosch, "How Did We Get Here?” n.d., < http://home.earthlink.net/ audra-bill/bio.htm> (12 January 2006); Bill Bosch, personal email (24 January 2006).
} 
by 1929, the Catholic population in Lynch was much greater than those who were members of Baptist churches. ${ }^{26}$

When immigrants began arriving in 1908, the coal companies established Catholic and Orthodox churches in most of the county's coal camps. However, for the next four years, the Catholic diocese did not appoint full-time priests to serve its small, but growing body of believers. Instead, priests from St. Boniface Parish at Jellico, Tennessee, visited Catholics to deliver mass and perform weddings, baptisms, and funerals. In 1913, the first Catholic Church was constructed in Benham. The owner of the Wisconsin Steel Company who owned the coal and coke plant in the model town of Benham donated the land and erected a wooden church for his Italian, Slav, and Hungarian Catholic workers. Bishop Mae, head of the Jellico Mission Center began conducting mass there once a month until Father Celestine, a Benedictine priest stationed at Stonega, Virginia, was appointed to head the Benham mission. In 1917, the opening of the United Coal and Coke mines at Lynch prompted Bishop Broussant's decision to place the county under his jurisdiction. Broussant, the head of the Covington, Kentucky, diocese, then assigned Father Jerome Lawrence to Lynch. Father Jerome remained in Lynch until 1919, when Father Alfred Hanses arrived. It was during Hanses’ tenure that Catholicism in the county increased and flourished. Hoping to "encourage the establishment of religion among what was otherwise an unruly labor force,” United Coal and Coke contributed land for the building of a new church as well as one-half of its construction costs in 1923. Located in the center of the town, the church, named the Resurrection Parish, was an impressive structure built by Italian masons, using stone quarried from Pine Mountain. Marble stones imported from Italy were laid near the altar.

${ }^{26}$ Cantrell, “Immigrants and Community,” 130-133. 
Local history has it that each immigrant family contributed enough money to purchase a stone to beautify their church. The church served all Catholics in the county until 1949, when St. Stephens was built in Cumberland. From 1918-1930, priests baptized more than five hundred infants in Lynch. ${ }^{27}$

The construction of beautiful, ornate churches that contained Italian marble such as the parish in Lynch certainly reminded Catholic immigrants of their beloved churches back in the Old Country. The buildings may have resembled those found in Europe, but like every other institution established in the Appalachians, the mountains shaped the way that both priests and laity practiced their faith. Catholicism has generally been known for its formality. In Appalachia, such formality failed to take root in the social setting of the mountains. The rough terrain, along with a shortage of churches and priest, and the lack of transportation meant that, in many cases, priests ministered to their flocks adopted the ways of circuit riding preachers: priests traveled throughout his assigned area, conducting mass, serving Holy Communion, and officiating at weddings, baptisms, and funerals in an informal manner that would be deemed inappropriate in more urban settings. In 1904, a priest assigned to a coal camp in southwestern Virginia found himself hastily baptizing a child in the woods above a town. Seeing the train approaching, he did not have enough time to take the child's name before boarding. Upon returning to his parish, he could not fill out the baptismal record until he received the baby's name in the mail. ${ }^{28}$

Catholic and Greek Orthodox priests fulfilled two needs in the coalfields. They ministered to the spiritual and emotional needs of believers and contributed to the

\footnotetext{
${ }^{27}$ Cantrell, "Immigrants and Community,” 130-133.

${ }^{28}$ Margaret Ripley Wolfe "Aliens in Southern Appalachia: Catholics in the Coal Camps, 19001940,"Appalachian Heritage 6 (1978) n. 15, 47.
} 
assimilation process. Catholic priests in southeastern Kentucky adapted their ministry to the rural setting. Reverend Clarence Meyer worked in the coalfields of Southeastern Kentucky and Northeastern Tennessee from 1926-1932, ministering to Italian immigrants. Although their facilities were limited, his parishioners "considered it a must to have their children baptized and to marry and be buried in the Catholic Rite.” The Catholic Church and cemetery in Jellico, Tennessee was the religious center of the Italian community. Its members considered the burial of their loved ones in such a cemetery an important "obligation." To this end, Father Meyer officiated at the funerals of many men who were killed in the mines. He also held religious services in homes throughout Southeastern Kentucky and Northeastern Tennessee, arriving there after hitching a ride on a railroad as far as possible and walking or riding a mule to his final destination. ${ }^{29}$

As Margaret Ripley Wolfe writes in "Aliens in Appalachia: Catholics in the Coal Camps, 1900-1940," "Catholicism provided a bridge from the past to the future for these immigrants in a Protestant nation.” As these immigrants prayed, sang, and responded to the words of their priests in their native tongue, they were able to maintain an important part of their heritage. This certainly provided strength and comfort to those struggling to adjust to a new environment. In addition, Catholicism contributed to the assimilation process. Before immigrants could become part of the cultural fabric of America, they first needed a sense of identity. In their homelands, they identified with their particular village, town, or city instead of their country. For example, those from Sicily did not consider themselves to be Italians before their arrival in America. Instead, they were Sicilians. In America, both urban and rural immigrants became conscious of their national origins and became Italians, Hungarians, Slavs, and Poles. Both the Catholic

\footnotetext{
${ }^{29}$ Margaret Ripley Wolfe “Aliens in Southern Appalachia,” n. 16, 47.
} 
and Greek Orthodox churches created a climate that encouraged the development of such identities, because in the coal camps, the church was the only location that provided a setting in which immigrants could congregate in distinctive groups. ${ }^{30}$

The second most important church to be transplanted from the Old Country was the Greek Orthodox. According to historian Doug Cantrell, very little is known about the Greek Orthodox church of Harlan. Evidently the Coal and Coke Company contributed to the building of a church in the early years of Lynch. Once the construction of this building was completed, a priest arrived to serve the Russian, Greek, and other Orthodox immigrants. The Lynch church failed after a depression in the coal industry drove out many immigrants of the Orthodox faith from the county during the 1920s. In 1928, a Baptist congregation purchased the building. ${ }^{31}$

The company used the church in order to create a patriotic, reliable, productive work force. U.S. Steel provided for the spiritual needs of its white and black miners as well. The corporation contributed the land and half of the construction costs for churches and provided meeting places for some local "associational” sects. However, such assistance certainly came, as Wagner and Obermiller point out, with "strings attached.” Mine operators gained some revenue from leasing the land. However, they realized the greatest return on their investment with the leverage they gained in the church's affairs. This was especially true when it came to the theology that emanated from their pulpits: for ministers who wished to retain their assignments made sure that their sermons reflected the company’s interests. As Memphis Tennessee Garrison observed, “[The companies] really weren't advancing anything; it was a church they were buying. They

\footnotetext{
${ }^{30}$ Wolfe, "Aliens in Southern Appalachia," 53.

${ }^{31}$ Cantrell, "Immigrants and Community," 132.
} 
would have a lot to say about what kind of preaching you had. The preacher would have to be in accord with the company's policy. There were always those who rebelled against certain things, but the church would have to go along with the company. ${ }^{32}$

The first two churches constructed with the financial assistance of U.S. Steel \& Coke in Lynch were the Community Church and the Mt. Sinai Baptist Church. Mainstream denominations such as the Baptist Church and the Methodist Episcopal Church, South held services for white families in the Community Church, but only blacks attended Mt Sinai Baptist. Once construction of these churches was underway, company architects began drawing up plans for a third church building that would serve the spiritual needs of its immigrant miners- the Roman Catholic Church of the Resurrection. By 1924, two more church buildings were under construction: Goode Temple African Methodist Episcopal Church and St. Nicholas Eastern Rite Orthodox (Greek Orthodox). Coal operators supported worship in other ways as well, but rarely were their motives not related to their bottom line. Their enthusiastic support of Evangelist Billy Sunday, long known for his diatribes against the "demon rum" and labor unions, perfectly illustrates what lie at the heart of such generosity. When Billy Sunday held a revival in the area in July 1922, the companies permitted their employees, both miners and managers, to leave their jobs for two hours to attend services. ${ }^{33}$

Immigrants living in all parts of the country, whether Northern or Southern, urban or rural, all faced intense discrimination, racism, and prejudice. World War I and the post war recession only made it worse. Thus, for immigrants in Harlan County and elsewhere, discrimination, racism, and prejudice became a part of every day life, and it

\footnotetext{
${ }^{32}$ Wagner and Obermiller, African American Migrants and Miners, 27.

${ }^{33}$ Wagner and Obermiller, African American Migrants and Miners, 84-85.
} 
surfaced the most often in name-calling. Italians were called "dagos or tallies," Hungarians, "hunkies or wops,” Russians were "Ruskies,” Poles, became "Pollocks,” and Asians were called "Chinks.” While immigrants resented the name calling, most ignored it, believing that it reflected native whites' lack of understand and toleration of cultures that differed from that of their own. In addition, most immigrants accepted name calling as a part of the way things were back then and did not give it much thought. Most immigrants forgave their white neighbors and coworkers. In doing so, they were exhibiting more compassion than most probably deserved. During the twenties, the rise of the Ku Klux Klan reflected the true feelings of many Americans. Quoting the words of Harry Caudill, many native whites thought that immigrants were “damn furrin’ sons of bitches... barely one notch better than niggers" and that "notch was a narrow one.”34 Despite such blatant discrimination, immigrants continued to come to Harlan County until the end of the 1920s. World War I virtually put an end to immigration to the United States when the many immigrants returned to their homeland. With the passage of the National Origins Act in 1924, immigration from Southern and Eastern Europe came to an end. Unlike miners living in the border states of West Virginia and Virginia, those who remained, continued to work as miners until 1928. U.S. Steel, International Harvester, and the Ford Motor Company maintained production at their mines since their total output went directly to power plants at their factories. However, when the stock market crashed in October 1929, these operations were finally forced to cut production. As a result, most of the county's remaining immigrants were forced to leave for industrial cities in the North to search for work. The good ole days were slowly coming to an end.

\footnotetext{
${ }^{34}$ Cantrell, "Immigrants and Community,” 137; Caudill, Night Comes to the Cumberlands, 104.
} 


\section{CHAPTER 5}

\section{AND THE WALLS CAME TUMBLIN’ DOWN ${ }^{1}$}

As the twentieth century dawned across the South, most African Americans were struggling to feed their families and keep a roof over their heads. Violence, intimidation, and Jim Crow continued to keep blacks in their place, at the bottom of the socioeconomic ladder. Since the majority of southern blacks were sharecroppers who did not own the land that they worked, these men and their families were in an especially precarious position. Boll weevil infestations and blights decimated any chance of having anything left after the landlord was given his share of the crops. That is, if sharecroppers had anything to harvest at all. Vast numbers of landowners lost their land by foreclosure as well. As a result, blacks began to look outside the South for employment. What had started as a stream had "swollen to a torrent” by 1910. During the next decade, between 300,000 and 1,000,000 African Americans left the South in what came to be known as the Great Migration. While the vast majority of migrants settled in industrial centers such as Detroit, Akron, and Pittsburgh, many set their sites on the coalfields of Appalachia. $^{2}$

Many of these migrants were experienced miners and highly sought after by coal operators in eastern Kentucky, southern West Virginia, and western Virginia. Black coal

\footnotetext{
${ }^{1}$ An old song “Joshua Led the Battle of Jericho," tells the story of the Israelites' conquest of the great, walled city of Jericho in Joshua 6. The people walked around the walled city once a day. On the seventh day, the priests blasted their horns. On the seventh day, the people walked around the city seven times. When Joshua gave the command, the people shouted, and the walls fell down. Such a deed would not have been deemed humanly possible. However, the people did as God directed, and they were given a great victory.

2 Michael H. Burchett, "Promise and Prejudice: Wise County, Virginia and the Great Migration, 19101920,” Journal of Negro History 82, no. 3 (1997): 312; Ronald L. Lewis, Black Coal Miners in America: Race, Class, and Community in Conflict, 1780-1980 (Lexington: University of Kentucky Press, 1987), 123-126.
} 
miners working in the mines of Alabama, Georgia, and Tennessee were paid less than white miners for the same work and usually worked in the most dangerous sections of a coal mine. A 1919 Department of Labor Report pointed out that "the Negroes most sought after in the Birmingham [Alabama] district have been the coal miners. There has been a constant demand in the mines of Kentucky, West Virginia, Pennsylvania, and Virginia for the experienced miners here.” ${ }^{3}$ Slick-talking labor recruiters, frequently called "spellbinders" promised higher wages and fair treatment to miners willing to relocate. These spellbinders were frequently ministers who were selected because of their eloquence and willingness to ignore the truth. Operators sent them to the South with instructions to "pick workers with strong backs and weak minds, as they give the least trouble.” Mine operators in West Virginia hired the greatest number of "spellbinders." West Virginia was especially attractive to black miners because of the relative absence of Jim Crow, its low incidence of lynchings, and equal wages paid for equal work. ${ }^{4}$ Historian Joe Trotter has documented the coalfield migration and noted that the African American population in central Appalachia alone increased by nearly 200 percent between 1900 and 1930, from less than 40,000 to over 108,000. ${ }^{5}$ Coal operators from Harlan County were successful in their recruitment efforts. By 1930, 11,624 male workers were employed in the county's coal operations; nearly 15 percent $(1,722)$ were black. $^{6}$

\footnotetext{
${ }^{3}$ Wagner and Obermiller, African Americans Migrants and Miners, 7.

${ }^{4}$ Burchett, "Promise and Prejudice," 313.

${ }^{5}$ Wagner and Obermiller, African Americans and Migrants, 7.

${ }^{6}$ Composition and Characteristics, Table 20, Persons 10 years and Over Engaged in Gainful Occupations, by Sex, Color, and Industry Groups, for Counties and for Cities of 25,000 or more: 1930; 1930 Population Census; Vol. III, Part I, $15^{\text {th }}$ Census of the U.S., (Washington, D.C.: Government Printing Office, 1932), 941.
} 
Like most of the other black migrants to Appalachia during this period, the black miners recruited to work in Benham and Lynch did not necessarily intend to remain in Appalachia permanently, but, as Wagner and Obermiller point out, they came with the same intentions: to obtain wage labor in order to help their families in the South. Armed guards may have ensured that miners could not escape from the locked box cars that transported them to the coalfields, but they could not prevent frequent trips back home to visit family and friends. Many miners hoped to make one, final trip home with enough cash in their pockets to buy a farm. In his study of black migrants to the coalfields of Wise County, Virginia, Michael Burchett found that some miners "used coal as a cash crop" that allowed them to keep their farms back home. During shutdowns, layoffs, or wage cuts, these miners returned to their farms and worked the fields until worked resumed in the mines. ${ }^{7}$

For southern blacks, Lynch was indeed the Promise Land. For the first time, experienced miners from Alabama received the same wages as their white counterparts. Segregation and racism co-existed, both above and below ground in Lynch. Nonetheless, black miners and their families enjoyed a lifestyle that would not have been possible in the Deep South. In 1921, the editors of Coal Age sent H.N. Eavenson to Lynch. His visits resulted in a series of installments he presented at the September 19 meeting of the American Institute of Mining and Metallurgical Engineers and published in subsequent issues in the industry journal. In these articles, he chronicled the evolution of U.S. Steel's coal production facilities and model company town in Lynch. In his third installment, Eavenson focused upon the construction of the town itself, from the miners' homes and utilities, to its ballparks, restaurants, and the grand company hotel. He found

\footnotetext{
${ }^{7}$ Michael Burchett, “Promise and Prejudice,” 320.
} 
that U.S. Steel had indeed furnished all that was "required for comfortable living” and declared that it was "fortunate that all the property was owned in fee simple and that there were no outside lots or owners to create embarrassment in laying out the town.”8 ${ }^{\text {That }}$ U.S. Steel owned the property without any encumbrances was part of the design and did not happen by chance.

Like miners in coal towns across Appalachia, the black miners in eastern Kentucky enjoyed wages, health care, and housing that exceeded anything available to them in the South. This was equally true for those living in the model towns of Benham and Lynch. The town of Lynch was laid out in six sections along the creek, with the first section downstream, closest to Benham, and the last section at the farthest point upstream. Once construction was complete, it filled the long, narrow bottom of the valley floor and spread up both hillsides. The mine portals, tipple, offices, store, schools, and other buildings that housed the mining operations were located at the center of the town. Two hundred single-family homes, four hundred double houses, and five boardinghouses with twenty-two bedrooms were constructed to house the company's employees and their families. In order to save land, most of the houses in Lynch were built as two-family units. To provide variety and avoid the monotonous coal camp look, twelve different house plans were used, and the houses were painted different colors. In 1925 a worker in Lynch who lived in a five-room house paid about $\$ 12.25$ a month rent. This included \$2 for each room, \$1.50 for electricity, and 75 cents for water. Having access to public utilities such as water, sewage, telephones, and electricity certainly differentiated life in a company town from rural life, and one of the major attractions was

\footnotetext{
${ }^{8}$ H.N. Eavenson, "Building Complete Thousand Dwelling Town for a Mine Population of 7,000 in Lynch, Kentucky, Coal Age Vol. 20 No. 14: 532.Berea College, Hutchinson Library, Southern Appalachian Archives, Vertical Files: Coal Mining.
} 
the availability of electricity. Only 10 percent of the nation's rural residents had electricity, compared to 70 percent of urbanites in 1932. This was not the case in mining towns since their operations required electricity for illumination, ventilation, and the operation of motorized equipment. In most instances, excess generation went to providing electricity to miners' homes and turned out to be a valuable recruiting tool. Most homes had one light per room. In Lynch, miners paid 30 cents per electric light, per month. Most homes had one light per room. The availability of clean water was another incentive. The water system was chlorinated and provided all of the needs of the mining operations and furnished up to fifty gallons per person daily to the town's residents. Water was piped into the houses, but only the homes of mine managers had indoor plumbing. The rest had outdoor toilets (outhouses) connected to the central sewage system. "Warm Morning” stoves fired with stoker or block coal, heated homes. When residents needed to purchase coal, they placed an order with the payroll office, and it was subtracted from the miner's paycheck. The company provided basic maintenance for the houses, but the miners were required to keep their homes and yards clean and neat. In addition, the company built a hotel with 108 bedrooms to accommodate visiting company officials and others needing temporary housing, a hospital, power plant, churches, and recreational facilities. ${ }^{910}$ The company also provided a fully staffed medical clinic to treat work-related injuries and up-to-date health care and support for miners and their families. Both white and black employees and their families were treated at the hospital and clinic, but patient wards were segregated.

\footnotetext{
${ }^{9}$ Wagner and Obermiller, African American Migrants and Miners, 78-79.

${ }^{10}$ Wagner and Obermiller, African American Migrants and Miners, 23-27; Thomas Kelemen, “A History of Lynch, Kentucky,” 59-65.
} 
Schools and churches were segregated as well. Initially, the children of U.S. Steel employees attended schools in Benham with the children of International Harvester employees. By the beginning of the 1920s, 850 students were enrolled in the Lynch schools, which had nine white and two black teachers. Initially, teacher turnover was a problem, a situation that was no doubt exacerbated by the number of non-English speaking students.

By 1928, both companies had constructed school buildings for black and white students. In that year, about nine hundred students were enrolled in the white school at Lynch, and 450 were enrolled in the black school. The facilities were segregated, but this did not affect the quality of education. The black schools in both Benham and Lynch attracted the best teachers available, with many having graduate degrees from prominent black colleges such as Fisk, Howard, and Tuskegee. Teachers with advanced degrees received bonuses and competitive wages and often spent their summers studying at major universities such as the University of Chicago. This quality was also reflected in the high school curricula for both white and black students, and classes were offered in English, mathematics, science, foreign languages, and history. Hence, it was not surprising that many of the students, both black and white, attended college after graduating from high school. Andrea Massey praised her black teachers. Massey remembered that her teachers "made sure that you learned. The teachers cared about you, making sure that you worked and that you understood before you left; that was their goal." ${ }^{11}$

Miners and their families also enjoyed shopping at large, well-stocked company stores similar to the department stores found in larger towns and cities. The residents of company towns eagerly embraced consumerism and the conveniences of living in town.

\footnotetext{
${ }^{11}$ Wagner and Obermiller, African American Migrants and Miners, 79-83.
} 
Anlis Lee, a black miner from Virginia, remembered the commissary at Lynch as something very different from the stores in his former hometown. U.S. Steel's commissary resembled department stores in larger cities, with its three floors that held everything, from produce and meat, to clothing and furniture. Large purchases such as automobiles could be ordered and purchased through the store. Miners, regardless of ethnicity or race, were treated equally at the company store. They were waited on a firstcome, first-served basis, were charged highly inflated prices, and most were forever in debt to the company store. A miner from Benham said it best when he stated: If you worked for a company, you stayed in a company house. You traded at the company store, you bought whatever you needed out of their store. If you didn't trade there, you didn't stay there. ${ }^{12}$

Seeing their children receive an excellent education that would open doors of opportunity and upward mobility was important to black miners. Realizing that such an opportunity rarely existed elsewhere certainly drove miners to remain in Lynch, even during the worst of times. For U.S. Steel, this served their interests in both the short and long term. In the short term, it provided the company with a stable work force while, at the same time, preparing the next generation of the nation's work force. Johnnie Jones came from Red Ore, an oil camp near Holt, Alabama. Upon arriving in Harlan County, he first worked at the Kitt Coal Company, went on to Benham, and finished his mining career in Lynch. Like other southern blacks, Jones left his native Alabama and "came to Kentucky, to try to better my condition, oh, which I did...I don't' believe I could have made it anywhere else. In fact, I know I couldn't at the Red Ore rates, I couldn't raise a big family. But after I came to the coalfields, I had to work hard though, but I made a

\footnotetext{
${ }^{12}$ Wagner and Obermiller, African American Migrants and Miners, 25.
} 
good living. Despite slowdowns, layoffs, and strikes, many black miners remained in Lynch. Knowing that their labor would be needed again soon, miners such as Jones found ways to survive the hard times. Jones, who was "laid off about three or four times," always found work in "little one-horse mines" until he "could get back to Lynch.”13

For black miners, life was good in the eastern Kentucky coalfields. They "made a good living," and housing and education far exceeded anything available to them in the Deep South. Incidents of racial violence were rare, but racism did exist. In Kentucky, Jim Crow laws enforced segregation above ground during the first half of the twentieth century. State law meant that housing, schools, and public facilities were segregated, and to an extent, so were mining operations. Except for those with prior mining experience, black miners received the same short end of the stick as immigrant miners: they were assigned to the most dangerous sections of the mine, to do the most backbreaking work. As one coal operator put it, "The best points of the colored coal loader are that he will work in wet places and in entries where the air is bad with less complaint than the white man.” Thus, black miners were frequently assigned to work in very low seams of coal, or areas that had excessive rock content, bad air, or prone to flooding. As a result, these miners found themselves working on their knees or bent over, working in "pools of water,” working on the mine's ventilation system or cleaning out tons of rock-- work categorized as "dead work" and not eligible for pay before the days of union contracts. ${ }^{14}$

As they gained work skills, miners functioned much like independent contractors. In doing so, they hired and supervised their own helpers and set their own hours.

\footnotetext{
${ }^{13}$ Wagner and Obermiller, African American Migrants and Miners, 18, 23

${ }^{14}$ Wagner and Obermiller, African American Migrants and Miners, 18.
} 
Memphis Tennessee Garrison remembered that operators would "let a Negro man take a section of his mines... He'd hire his own men and work it; they'd pay him for it and he'd pay his miners.” This was especially true before automation, when miners were paid by the ton. Before mechanization, coal miners generally controlled the size of their pay, working as much or as little as needed. As mines mechanized and the coal market declined during the late 1920s and early 1930s, miners faced frequent periods of unemployment and wage cuts, conditions that increased the effects of racism. As a result, survival meant the ability to produce more coal. This was especially true for black coal loaders, but the work ethic that they brought from the agricultural fields of the South served them well, especially during periods such as these. ${ }^{15}$ Reverend James Hannah found himself in this position when he began working as a miner for the R.C. Tways Coal Company on Martin’s Fork, near Harlan Town. Hannah was born in 1912 and grew up in Etowah County, in Alabama. He came to Harlan in 1933 and began working as a coal loader.

The news that the color of their skin would no longer be a barrier to earning equal pay for equal work or their children receiving a quality education, thousands of southern blacks migrated to the coal fields. That the work would be physically taxing and dangerous did not matter. Southern blacks such as Hannah were used to hard work. Adjusting to living and working in the new, industrial order surely tried even the strength of the strongest men, but they persisted. In time, many black miners acquired the skills to drill, undercut, blast, and load coal at the mine's face, working in job classifications that paid good, steady, wages. Yet, even in boom times, many black miners preferred to work

\footnotetext{
${ }^{15}$ Wagner and Obermiller, African American Miners and Migrants, 19-20/
} 
as loaders, because it paid more than other manual labor jobs and offered them opportunities to work independently, without supervision.

Reverend Hannah worked for R.C. Tways until the mine closed, sometime before 1939. He and his family probably lived in the coal town of Tway, a medium sized coal town that was home to the men who worked in the company’s two mining operations. Each operation employed approximately 250 miners, but Tway’s miners did not enjoy the same level of working and living conditions as did their peers who worked for International Harvester and U.S. Steel in Benham and Lynch. ${ }^{16}$ In 1939, Hannah tried to get a job at U.S. Steel. The company called the miner in to take a pre-employment medical examination. Unfortunately, he applied during an organizing drive, and upon learning that Hannah was a "union man” the company doctor told him that he had failed the physical and was unemployable. According to the doctor, Hannah’s heart was “so bad," that he was "liable to fall dead" before he left the office. ${ }^{17}$ This was the first and last time that Hannah failed a company physical or was turned down for employment. U.S. Steel wanted skilled miners regardless of the color of their skin, but not if they were union men.

U.S. Steel's anti-union arsenal contained both carrots and sticks. U.S. Steel hoped that constructing a model community such as Lynch, employing a judiciously mixed work force, and maintaining a well-armed police force would impede the formation of working class consciousness and keep out the union. In the beginning, black company preachers were especially useful in this regard.

\footnotetext{
${ }^{16}$ Bill Bosch, “Coal Towns in Harlan County,” < $\underline{\text { http://www.home.earthlink.net/ audra-bill/towns.html }>~}$ (4 June 2005)

${ }^{17}$ Interview with Reverend James Hannah, Southeast Community College, Appalachian Archives, Oral Collection.
} 
When southern blacks migrated to the coal fields of Central Appalachia, they took their religious beliefs and values with them. Church attendance was important to Southern blacks. As it was for other Christians, black believers enjoyed the fellowship and spiritual nourishment that the church offered. Yet the church held a special significance for African Americans. Since Reconstruction, the church had been the only institution that did not fall under the jurisdiction of whites. ${ }^{18}$ In the South, the majority of blacks attended the Baptist church, followed by the American Methodist Episcopal Zion and Holiness-Pentecostal churches. While the church was important to the entire coal community, it held a special significance in the black community. For as one black miner from West Virginia said, "We never left church out... I was born in the church... and the church was the only thing we had." ${ }^{, 19}$ Thus, finding a new church was important to black miners and their families, and once settled, they usually joined established congregations of the same denomination or sect that they had previously attended. If none was available, they started a church of their own. ${ }^{20}$

Coal operators realized that the importance of the church presented them with a golden opportunity, and few failed to capitalize on it. As they did with their other churches, operators provided land and buildings to the congregation, but the membership was expected contribute to the church’s expenses. Like other churches in the community, black churches held fund-raising rallies and bake sales and collected special offerings to pay off mortgages, the preacher's salary, or maintenance. ${ }^{21}$ The preacher tended to the

\footnotetext{
${ }^{18}$ Winthrop S. Hudson and John Corrigan, Religion in America: An Historical Account of the Development of American Religious Life, $6^{\text {th }}$ ed., (Upper Saddle River, NJ: Prentice-Hall, Inc., 1999), 222-223.

${ }^{19}$ Joe Trotter, Coal, Class and Color: Blacks in Southern West Virginia (Urbana and Chicago: University of Illinois Press, 1990), 178.

${ }^{20}$ Trotter, Coal, Class, and Color, 177-178.

${ }^{21}$ Trotter, Coal, Class, and Color,178-180; William E. Montgomery, “Black Preachers,” 298-299.
} 
spiritual needs of his congregation, rendering emotionally charged sermons for Sunday worship services, funerals, and baptisms. Their influence extended beyond the spiritual. They appealed to the intellectual and material interests of blacks, especially after World War I, as expectations for social and economic advancement failed to materialize. Thus, in the postwar period, sermons contained more than the usual spiritual exhortations; they contained liberal doses of logic and instructions geared to the working world. In doing so, black ministers assisted industrialists with the construction of the new, industrial order that required workers to be loyal, hard working, and sober. Along with the usual sermons on the need to repent and be saved, black preachers railed against the evils of gambling, excessive drinking, adultery, stealing, and the evils of labor unions. ${ }^{22}$

Visiting preachers and evangelists occasionally traveled to coal camps to hold special meetings and revivals or came in hopes of planting a church of their own. In some instances, however, visiting clergy came with the most unspiritual of motives and traveled to towns such as Lynch and Benham to exhort miners to remain loyal to their paternalistic employers. Reverend J.C. Brewer, a Methodist minister from Chicago, frequently visited the coalfields of eastern Kentucky. In 1922, George Ranney, secretary and treasurer of Wisconsin Steel Company, wrote to the superintendent of the Benham operations concerning Brewer’s visits. In it, Ranney described a conversation that he had had with Brewer when the minister visited him asking for financial assistance to a meeting to be held at Middlesboro. According to Ranney, Brewer was a Methodist minister who traveled throughout the South "acting more or less as a free lance, going from camp to camp, trying to show his people the advantages which they enjoy and keep them happy and quiet.” Ranney agreed to loan the minister fifteen dollars, but he asked

\footnotetext{
${ }^{22}$ Trotter, Coal, Class, and Color,183-185.
} 
O’Connell to "make some inquiries” about the preacher's work ${ }^{23}$. This minister evidently left a favorable impression with the company’s secretary/treasurer, but the company's frequent contributions to black ministries did not mean that they were promoting racial equality. The opposite is true: they were buying the loyalty of their black workers. Supporting individual black ministers and churches were part of companies such as U.S. Steel and Wisconsin Steel's anti-union arsenal. In most cases, they regarded black ministers and their churches as necessary nuisances. Superintendent Connell relayed in a subsequent letter to C.F. Bigger, the vice president of Wisconsin Steel concerning the possibility of making a contribution to the building fund at Simons University at Louisville, a Baptist seminary for black students. McConnell advised against making such a contribution and urged that any available funds be used to build a school for the black students of Benham, who, at the time, were attending school in a church and tenement house. ${ }^{24}$

At first glance, the company demonstrated a "benign tolerance" for all workers, regardless of race or ethnicity, but, management held the same stereotypical views as most Americans at the time. Evidently Wisconsin Steel reduced the number of black clergymen in Benham. The 1930 census indicates that the town of Benham had only one black clergyman on salary. The city of Lynch counted three black Baptist preachers out of a total of seven, and the rest lived in Harlan Town. Of the nine men who listed their occupation as clergy, five were black: three presided over Baptist congregations and the rest filled the pulpits of the county seat's Methodist churches. ${ }^{25}$ The black Baptist churches remained strong and continued to grow. By 1936, their congregations had

\footnotetext{
${ }^{23}$ Southeast Community College, Appalachian Archive, Benham and Lynch MSS, Box 25, fol 22.

${ }^{24}$ Southeast Community College, Appalachian Archive, Benham and Lynch MSS, Box 25, fol 22.

${ }^{25}$ NARA, 1930 Census.
} 
virtually doubled in size, from 1103 members to 2260. The African Methodist Episcopal Church, however, was not as fortunate in the same period as its congregation was reduced by half. ${ }^{26}$ Sects such as the Church of God were also attracting new converts from the black community, and, as I have previously mentioned, in 1936, the Kentucky Church of God's (Cleveland, Tennessee) three, black congregations were all located in Harlan County.

As Wagner and Obermiller point out, miners and their families were aware of racial differences, but like the southern and eastern European immigrants, most "chose not to dwell on them.” James Laing conducted interviews with black miners working in West Virginia during the 1930s and found that relations between black and white miners were positive, even friendly. Race consciousness existed to a limited extent between miners, but it was greater among their children, teachers, and preachers. ${ }^{27}$ His findings are not surprising considering that black and white miners worked side-by- side underground. However, neighborhoods, schools, and recreational facilities were segregated. Since black and white miners labored under the same conditions, day in and day out, they had more opportunities to forge positive relationships with one another. On the other hand, their wives and children had very little opportunity to mingle. The Bosch children knew black miners, because they worked for their father and regularly came to their home to collect their pay statements. The sons and daughters of white and immigrant miners did not attend the same churches, schools, let alone play on the same sports teams, or sit in the same section of the theater with black children. ${ }^{28}$

\footnotetext{
${ }^{26}$ U.S. Department of Commerce, Bureau of Census. Religious Bodies: 1926 and 1936, Table 32.

${ }^{27}$ James T. Laing, "The Negro Miner in West Virginia," in Blacks in Appalachia, William J. Turner and Edward J. Cabbell, ed. (Lexington: University of Kentucky Press, 1985), 76-77.

${ }^{28}$ Email from Bill Bosch. n.d.
} 
By the Depression, race relations were relatively cordial. As historian Ron Eller points out in his book Miners, Millhands, and Mountaineers, except for state-mandated segregated schools and public facilities and segregated neighborhoods, coal companies treated black and white miners the same. Differences in housing, and living conditions did more to promote working class consciousness than racial animosity. ${ }^{29}$ Except for southeastern Kentucky, the Depression made an early entrance into Appalachia in 1924 as the demand for steel declined and competition from other fossil fuels signaled an end to the coal boom. Harlan's miners and operators continued to prosper until Black Friday. In spite of this, the Klan grew in power and prominence in Harlan as well. In the spring of 1931, Thomas Bunker visited Harlan County as a journalist for Class Struggle, the official newspaper of the Communist League. This was not his first visit to the county. Bunker's first trip to Harlan took place in 1924 as an employee of the Louisville and Nashville Railroad. Economic conditions had certainly deteriorated in the interim, but racial relations had definitely improved. During the 1920s, the "Ku-Klux-Klan ruled" in the county. Bunker remembered witnessing "hooded sheet parades, and fiery crosses on the mountainsides," symbols of the Klan’s "movement to oust the Pope and keep the nigger in his place.” Bunker perceived the Klan’s latter objective especially interesting in light of the interracial solidarity that would take place in $1931 .^{30}$ By the end of 1920s, interracial solidarity supplanted interracial conflict as the living and working conditions that characterized coal town life united miners, regardless of ethnicity or color.

\footnotetext{
${ }^{29}$ Ronald D. Eller, Miners, Millhands, and Mountaineers: Industrialization of the Appalachian South, 1880-1930, (Knoxville: The University of Tennessee Press, 1982), 171-172; Wagner and Obermiller, African American Miners and Migrants, 37.

30 Thomas Bunker, “Civil War in Harlan County,” Class Struggle (June 1931); http://www.weisbord.org/OneTwo.htm (4 May 2006).
} 
Company towns such as Lynch and its nearest neighbor, Benham, another model town owned by International Harvester, were planned communities. However, instead of being designed by urban planners, engineers drew up the plans for towns such as Lynch and Benham to fulfill their primary purpose-- the production of coal. ${ }^{31}$ U.S. Steel estimated that if they were to achieve the desired production of 8,000 tons per day, the company would have to maintain a work force of two thousand miners and four thousand persons working above the ground in various capacities. Lynch, which was located in a narrow valley between mountains with extremely steep sides, could not hold more than seven thousand inhabitants. ${ }^{32}$

By 1930, operators and boosters had realized their goal with five major coal areas in production:

1. Puckett's Creek, whose mines were owned by the Insull Coal Company and Black Star Coal Corporation;

2. Wallins Creek, with operations owned by the Kentenia Corporation, the Ford Motor Company, and the Creech Coal Company, one of the few locally owned companies;

3. Clover Fork, the richest section whose eleven operations included those owned by Harlan Wallins Coal Corporation and Harlan Colleries;

4 .Martin’s Fork, whose ten companies were owned by Harlan Fuels, R.C. Tway, and Mary Helen Coal Corporation; and

4. Poor Fork, the location of the giant captive mines owned by Wisconsin Steel (International Harvester), U.S. Coal \& Coke (U.S. Steel) and Harlan Central

\footnotetext{
${ }^{31}$ Wagner and Obermiller, African American Miners and Migrants, 55.

${ }^{32}$ Eavenson, "Building," 532.
} 
Coal Company's mine at Totz. ${ }^{33}$ In spite of such success, the boom would soon be over.

The people of Harlan County soon realized that their courts, boards of education, churches, and social organizations could not keep up with the rapid changes taking place within their communities. As the population increased, so did the crime, drinking, and gambling. Incidents of illness and disease increased as well. Country people, who were used to drinking water from nearby streams, creeks, and springs fell victim to typhoid fever upon drinking from streams contaminated by the waste that flowed from outdoor privies. ${ }^{34}$ Family life suffered as well. In earlier times, life revolved around the family farm, and the family was the basic social unit. The social order of the family changed from patriarchal to matriarchal as fathers laid aside their hoes and plows for picks and shovels. The long hours spent underground meant that fathers were no longer active participants in the lives of their children or marriages. The divorce rate skyrocketed. Divorce was still considered taboo, but it had become a necessary evil by the 1930s as one of every four local marriages ended in divorce. Child desertions and venereal disease became serious problems. ${ }^{35}$ Men and women may have had little control over events occurring within their families, but they had even less control over what happened once they stepped outside their homes.

As the coal boom of the 1910s turned to the bust of the 1930s, living and working conditions rapidly worsened. Those who had signed employment contracts with the operators who belonged to the Harlan County Coal Operators Association surely must

\footnotetext{
${ }^{33}$ Paul F. Taylor, Bloody Harlan: The United Mine Workers of America in Harlan County, Kentucky, 19311941 (Lanham: University Press of America, 1990),13.

${ }^{34}$ Thomas A. Kelemen, “A History of Lynch, Kentucky, 1917-1930,” (Ph.d., diss., University of Kentucky, 1972), 24-25.

${ }^{35}$ Hevener, Which Side Are You On?, 25-26.
} 
have felt as if they had signed their souls over to the Devil himself. With nearly two thirds of the county's population living in unincorporated company towns, mine owners exercised a great deal of control in the social, economic, and political lives of miners and their families. Whether they lived in primitive coal camps that were home to a few dozen individuals or the model towns of Benham and Lynch where five to ten thousand residents were squeezed into the floor of the valley and up the steep mountainsides, it was useless to complain. The coal operators practiced a paternalism that was far from fatherly and controlled all facets of community life. As a result, miners soon realized that the rights that they had once enjoyed as American citizens were gone. Mine company superintendents governed the company camps and towns and policed them with deputy sheriffs. These sheriffs were appointed and commissioned by the county sheriff and judge, but they were paid and controlled by company superintendents. As a result, miners frequently faced the gun barrels of deputies.

Miners who were fortunate enough to arrive at the county jail without being severely injured usually remained there until the date of their trial. Few miners were acquitted. Before industrialization, the law was firmly in the hands of local citizens. Defendants knew that they had a good chance of being acquitted if they or their families were of good reputation. Juries were indeed composed of one's peers and frequently included family members, neighbors, and friends of the accused. The residents of company towns were denied juries of this type, since jury participation was limited to property owners. As a result, juries composed of coal company owners, supervisors, and their allies usually found miners not guilty. ${ }^{36}$

\footnotetext{
${ }^{36}$ For a discussion of the loss of civil liberties andchanges to the judicial system in Appalachia during Industrialization, see John Hevener, Which Side Are You On?22-23; Ronald D. Eller, Miners, Millhands,
} 
In spite of the oppressive conditions that prevailed in Harlan's coal towns, opportunities for steady work and good wages attracted miners to the county throughout the twenties. Between 1911 and 1930, the number of working miners had increased from 169 to 11,920, and the make-up of the work force was remarkably different. During the 1920s immigration restrictions and increased opportunities in post war Europe had resulted in the exodus of most of the county's immigrant population. As a result, by 1931, most of the county’s miners were native whites and southern blacks. Since most of the miners had been recruited from mountain counties from Kentucky and those on its borders, the population had, overall, maintained its homogeneity. The population of Harlan County was once again comprised primarily of native-born whites. In 1930, 90 percent of the county’s 64,557 residents were native-born whites; only 9 percent were black; and 1 percent was foreign-born. ${ }^{37}$ As a result, there was little need for mine operators to post work and safety information for foreign workers or for the United Mine Workers Union to hire foreign-speaking organizers or publish articles in the United Mine Workers Journal in Italian, Polish, or Hungarian. When the union sent organizing teams into the county, most of the organizers were white. A few of the organizers were black, but none were foreign born and bi-lingual. Racism had not totally disappeared with the immigrant exodus, but by 1930, overall, the company town system failed to thwart the development of a working class consciousness among the miners. This was in true in the fiefdom of Lynch as well.

and Mountaineers, 210-219; Ronald L. Lewis, Transforming the Appalachian Countryside: Railroads, Deforestation, and Social Change in West Virginia, 1880-1920 (Chapel Hill and London: The University of North Carolina Press, 1998), 103-129; and Altina L.Waller, Feud: Hatfields, McCoys, and Social Change in Appalachia, 1860-1900 (Chapel Hill: University of North Carolina Press, 1998), 141-150.

${ }^{37}$ Hevener, Which Side Are You On? 3. 
In time, the carrots lost their flavor and were outnumbered by the sticks. Miners and their families certainly enjoyed a variety of advantages that were not found in most of the county's coal camps. Besides the quality of life in the community, miners enjoyed steady employment in two of the nation's safest coal mines. Thus, Lynch maintained its reputation as being a "hot bed of resistance" to union organization well into the thirties. In spite of the company's best efforts, this "hot bed of resistance" was cooling.

Discontent was apparent, both underground and on the surface, and the honeymoon was coming to an end in Lynch. Despite the quality of their homes, schools, and community organizations, mining families could never realize the American Dream of owning their own homes. Nor could they live as free Americans. Their comings and goings as well as their mail were monitored, and rights guaranteed to Americans under U.S. Constitution ended at the Harlan County line. Miners had no voice in the running of their community or schools. In addition, without union representation, miners had no voice when wages were cut or problems occurred underground. Those who voiced displeasure with company operations or policy were fired, evicted, and blacklisted. Consequently, even the miners at Lynch grew weary of receiving the blunt end of the company's stick. As a result, more and more miners were looking to the United Mine Workers of America for relief, and the company responded as predicted. As they did in other U.S. Steel subsidiaries, police officers from Lynch received special training at a school near Washington, D.C., that specialized in anti-union tactics. Normally, the company maintained a small police force at Lynch, which consisted of nine to ten officers. However, during times of union activity, the police force expanded rapidly and used intimidation, shows of force, and violence to tie the hands of union organizers and 
keep miners from joining the union. In addition, union organizers were not allowed to leave the highway that provided the only access to Lynch and suspicious persons were asked to leave. The movements of organizers were restricted in areas that were not owned outright by the companies such as the bank and independent churches, the only organizations that held free title to their land. ${ }^{38}$

The total systems approach failed to thwart the formation of working class consciousness in Benham, Lynch, and the rest of Harlan County. By 1931, most of the miners had lived and worked in the Harlan County Coal Operators' kingdom for more than a decade. During this period, whether native white, black, or immigrant, miners realized that they had more in common as miners than the operators thought. While the physical characteristics that differentiated the various racial and ethnic groups naturally remained, others had blurred. This was especially apparent in the immigrant community. Hoping to achieve a better life for their families, most immigrants eagerly took advantage of employer-sponsored citizenship schools and learned to speak English and acquire the knowledge necessary to obtain their citizenship papers. Racial relations had improved as well. As I have discussed earlier in this chapter, Thomas Bunker's observations on the ability of black and miners to work together in the union movement points to the changes that had occurred in Harlan since his first visit in 1921 when the Klan figured prominently in the county. The company's support of company churches and clergy had also failed. This was also true in the case of black miners who had long been considered an obstacle to unionism. As Brian Kelly points out, black miners, like their white counterparts, preferred to worship in churches outside the scrutiny of company officials and company preachers. Thus, it is not surprising that they, too, were attracted to the

${ }^{38}$ Thomas Kelemen, “A History of Lynch,” 69-70; 93-95. 
preaching of independent preachers, especially those that belonged to HolinessPentecostal sects. ${ }^{39}$

This was certainly the case in Harlan County. Ed Johnson was a black bishop (ordained minister) with the Church of God (Cleveland, Tennessee). Originally from Alabama, he and his wife Hattie went to Harlan to plant black churches in the county in 1926. When the couple arrived, there were no black churches in the county. A decade later, the Johnsons had established "colored” churches in Tways, Kenvir, and Kildav, camps where Blacks made up the majority of the work force. ${ }^{40}$ Such brotherhood extended to the UMWA with the establishment of union locals in these, three camps and proved that operators could not use the race card against miners.

Thus, by the start of the Depression, class interests exceeded differences based upon ethnicity and race. The quality of education attributed to the homogenization of the county's work force as well, a factor that has not been addressed in the historiography of the mine wars up to this point. Regardless of ethnicity or race, increasing numbers of children were staying in school during the 1920s. The quality of the schools in Benham and Lynch contributed to the stability of the work force in both communities. This was especially true of Lynch, with its large number of black students whose parents and grandparents knew all too well of the limitations of illiteracy. For miners with children in the black school at Lynch, education proved to be a strong reason to remain in Lynch, even in the worst days of the Depression when the mines only operated four or five days a month. In 1938, the Lynch operations employed 2,500 persons. This included “57 percent white Americans, 7 percent foreign-born, and 36 percent colored.” Henrietta

\footnotetext{
${ }^{39}$ Brian Kelly, "Sentinels for New South Industry: Booker T. Washington, Industrial Accommodation, and the Working Class Under Jim Crow," published paper, in possession of author.

${ }^{40}$ Hattie Johnson, The Church of God Evangel, 1936.
} 
Sweatt, who first came to Lynch in 1923 to teach at the Colored School, stated that the quality of life, especially as it related to education, that was available to black miners and their families surely convinced many to stay. ${ }^{41}$

In the end, company investment in separate churches for blacks and whites failed to impede the unity of the working class. Church attendance and membership provided miners and their families with a sense of belonging and unity. Blacks and whites often worshipped together in special revival meetings and community-wide, holiday services. In some classes, black and white congregations shared the same facility, as was the case in community churches located throughout Harlan County. These churches also strengthened the social fabric connecting the church and community through the various societies available to women as well as men. The entire community frequented socials, bazaars, and bake sales sponsored by groups such as the Methodist Ladies Aid Society, and the Catholic Ladies Society. These groups were especially valuable to the members of Holiness-Pentecostal churches, both black and white, who found themselves on the outside, looking in because they were miners and religious radicals. The Church of God established a Ladies Willing Workers Band (L.W.W.B.) in 1936, an action that was important to both the local church and the Kentucky Church of God as well since this was the first L.W.W.B. organized in the state. Auxiliaries such as the L.W.W.B. sponsored chicken dinners, candy and bake sales, and sold box lunches and fried pies. The workers' bands at Lynch and nearby Loyall became "famous" for their fried pies. Bill Bosch fondly remembers the fried pineapple pie sales held in his school. Activities such as

\footnotetext{
${ }^{41}$ Wagner and Obermiller, African Migrants and Miners, 74.
} 
these generated funds that were contributed to church building and renovation funds as well as various social and mission activities. ${ }^{42}$

Tragedy and sorrow frequently united the mining community as well. Miners constantly faced dangers underground, and, in times of crisis, blacks and whites came to one another's aid. ${ }^{43}$ Hence, mutual need brought families together, as families came together to nurse the sick and comfort the grieving. Regardless of race or ethnicity, miners shared common grievances as well. Except for segregated housing and schools, all miners paid the same exorbitant prices at the company store, had no say in regards to problems at the work place or in the running of the company town, and were subject to violence and intimidation at the hands of gun thugs. Thus, with the passage of time, the miners acquired working class consciousness. Their days of acquiescence had come to an end. Even in the fiefdom of Lynch.

The successes and failures of organizing drives of 1933 and 1935 would teach both the rank and file and the leadership of District 19 valuable lessons. Organizers and local leaders would have their work cut out for them, especially in the fiefdom of Lynch. U.S. Coal \& Coke, the county’s largest producer, was not a member of the Harlan County Coal Operators Association and successfully warded off attempts by the UMWA to organize its mines. U.S. Steel's vehement anti-union policy came to be known as “Garyism” after the company’s principle officer between 1901 and 1927, Judge Elbert H. Gary. The judge had established the giant steel producer’s labor relations policy in 1901 when he declared that the company would not "deal with labor unions” in any manner. ${ }^{44}$

\footnotetext{
${ }^{42}$ The Church of God of Kentucky, 158, 187; email from Bill Bosch to author, n.d.

43 Joe Trotter, Coal, Class, and Color, 287.

44 John A. Barb, "Strikes in the Southern West Virginia Coal Fields, 1912-1922”( M.A. thesis, West Virginia University, 1949), 122-125.
} 
On June 3, 1933, in line with U.S. Steel Corporation's national labor policy, the subsidiary established the Union of Lynch Employees (ULE), an organization that the Harlan Daily Enterprise judged an appropriate substitute for the UMWA, one that was charged to be "harboring radicals and Communists." In spite of the company's new union, the UMWA continued with its plans to organize the company's thirty-two hundred miners, an objective that union officials considered to be the key to the successful organization of the county. ${ }^{45}$

A month later, the UMWA established Lynch Local 6067 and soon recruited nine hundred members. When the local held its first public meeting in nearby Cumberland, Lynch company officials monitored the meeting. The next day, the chief mine inspector summoned the local's newly elected president, James Westmoreland and warned, "If you are going to sign up with John L. Lewis and William Turnblazer, I will fire the last one of you. ${ }^{46}$

The campaign was a difficult one. On 24 November 1933, Turnblazer wrote Vice-President Philip Murray. In this letter, he discussed the problems that organizers were confronting in the most recent campaign to organize the miners at U.S. Coal \& Coke. Of special concern was the opposition of the company's black preachers to the UMWA:

At the present time they are doing everything they can to intimidate our people in the Lynch camp. Secretary Norris continually has one of the Lynch policemen at his side when he is in the camp; when he goes in to work in the morning he is standing there, and when he comes out at night he is standing there. We have considerable [sic] amount of Negroes working.

\footnotetext{
${ }^{45}$ Hevener, Which Side Are You On? 104-105.

${ }^{46}$ Hevener, Which Side Are You On? 116-117.
} 
At Lynch, all the Negro preachers are using their influence and some who hold official positions in the fraternal organizations are working at the behest of the coal company. It is about a 50-50 proposition between the white and colored. We practically have all the white miners signed up, and I feel when the election is held these darkies will not have to courage to come out and vote against it, therefore, we will be in very good shape. ${ }^{47}$

Black preachers’ opposition to the drive was not the union's only problem. Neither were they considered to be a real threat to a successful organizing drive. The great steel company's political and financial resources were bulwarks to union organizing, and the company's clout extended all the way to nation's capital. Its officers were committed to Garyism and were determined to keep the union out of its mines and mills, even if it meant defying federal authority. Thus, the union’s organizers were thwarted at every turn, and the drive of 1933 suffered a crowning blow the following year when the president and vice president of Local 6067 were fired for creating a fire hazard. Local president James Westmoreland had been distributing one-page union handbills to miners as they boarded the mantrip. Upon discovering this, the company fired Westmoreland. His dismissal occurred six days after Albert E. Timmons, a local mine committeemen, had been fired for failing to set his safety timbers. After they were fired, Westmoreland and Timmons submitted a grievance to the Union of Lynch Employees’ grievance committee but were refused a hearing. They then took their case to a labor board in where the board ruled that the men had indeed been fired for union activity and ordered their reinstatement. When the company refused to comply, the board referred its decision to the NRA's Compliance Board, where it became tangled up in red tape and was never enforced. The UMWA spared Westmoreland and his family hardship by appointing him

\footnotetext{
${ }^{47}$ Letter from William Turnblazer to Philip Murray, 24 November, 1933, Pennsylvania State University, Paterno Library, Historical Collections \& Labor Archives, UMWA MSS Box 89, fol 3.
} 
as a county field representative, but did nothing for Timmons, who was the father of seven children. ${ }^{48}$

The iron grip of the coal company and the government's inability to enforce the law must have shaken the working class' faith in the ability of even the federal government to protect their constitutional rights in Harlan County. As early as December 1933, local miners had accurately assessed the board's potential impact in the county when two fired Lynch miners wrote the president, "but we are really beginning to wonder if the N.R.A. really means anything to us-if it is a guarantted [sic] right of the American citizen, then we begin to wonder if this right is not given to us." ${ }^{49}$ In two years of operation, the Bituminous Coal Labor Board received ninety-one complaints from the county; held seven formal hearings, all but two of them exparte because the invited operators refused to attend; and issued six decisions. None of the six decisions was voluntarily complied with or enforced. A mine foreman at Clover Fork succinctly summed up most Harlan operators' attitude toward the NRA. When union miners refused to work beyond code hours, the foreman ordered them to either get back to work or get out of the mine, declaring, "Roosevelt's not running this mine, and we are not working any seven hour shifts.”50 This, coupled with the international's stubborn refusal to adequately support the district's attempts to organize Harlan County, once again told miners that, if they were going to gain union recognition, it would have to be done on their own. Until 1937, the union faithful continued to recruit new converts under the cover of darkness.

\footnotetext{
${ }^{48}$ Hevener, Which Side Are You On? 116-119; “Appeals to Roosevelt,” United Mine Workers Journal, 1 May 1934.

${ }^{49}$ Hevener, Which Side Are You On? 120-121.

${ }^{50}$ Hevener, Which Side Are You On? 120.
} 
Fellow Lynch miner Adie Dossett was only six years old when he and his family moved to Lynch in 1924. Dossett remembers Lynch as "a good place to live and work- if you were not a union man.” Dossett, who later became a minister, remembered the days when miners risked paying a steep price for taking the union obligation. Once, upon hearing that a group of miners had joined the union, company officials called the men into the office. One by one, each man entered the office and was questioned. If a man admitted to signing a union card, a company official asked him to drop his union card into the waste basket in exchange for a shot of whiskey. If he agreed, the miner returned to work. Those who refused to relinquish their membership card had to be out of the camp by nightfall. Reverend Dossett recalled the time when "several hundred men" were forced to leave their jobs and homes because they belonged to the union. The miners realized that, if a union was to ever be established in Lynch, they would have to recruit members, one by one, until the group was large and strong enough to meet as a group and demand recognition. Being hired as an official union representative would mean the kiss of death to an individual's employment. Thus, like many union stalwarts at Lynch, Dossett worked alone, drumming up support for the union, under the cover of darkness and secrecy.

In the beginning, he spoke to miners in secret, one by one, explaining the benefits of union representation as well as the risks involved. If a man "took the obligation" and signed a membership card, he did so, without the emotional and intellectual benefits that such a brotherhood brings. That these men did not initially reap the benefits of union brotherhood, failed to dampen their commitment to the union and one another. ${ }^{51}$

\footnotetext{
${ }^{51}$ SECC, Appalachian Archives, Oral History Collection, Interview with Reverend Adie Dossett, by Ethel Clark, 2 April 1982.
} 
Otis King was another miner and union stalwart at Lynch who began working in the mines at the age of sixteen, at the close of World War I. To Otis King and many of his peers, taking the obligation and joining the union was similar to becoming a Christian and joining the church. Both were sacred obligations. In taking the obligation, miners took an oath that sounded much like a "prayer" that brought miners into the union in the same way that saying a prayer brought "brothers and sisters together," in one accord, in the church. King, who was saved in 1939 and called to the ministry two years later, recalls taking the obligation as a "stiff obligation" that required that a man "never wrong your brother." As did the rest of the miners at Lynch, King and many of his fellow miners took the obligation in secret, usually meeting on a "river bank towards Evarts" where a man would be present to "give us a... obligation." 52

As Dossett remembers it, “men were members of the union without his fellow men working around him knowing it. It was just a gradual thing that they grew into.” Once enough men joined “to carry enough weight," union leaders began to hold meetings in secret, meetings the details of which were not revealed to any man who had not taken the obligation. This went on for several years before the union had a large enough membership “to ask for something." 53

\footnotetext{
${ }^{52}$ University of Kentucky Oral History Collection; Appalachian Oral History Project; Alessandro Portelli Project, Interview with Otis King , 22 December 1989.

${ }^{53}$ Interview with Reverend Adie Dossett.
} 


\section{CHAPTER 6}

\section{REVOLUTION IN THE COAL FIELDS: UNION CRUSADES IN BLOODY HARLAN}

Appalachia's coal miners found that the good days were short lived and rare. As a whole, the nation's coal industry suffered a severe economic downturn during the early 1920s, but the coalfields of eastern Kentucky were spared until the early spring of 1931 . Until the Depression, the coal industry in Harlan expanded rapidly for four reasons: first, with its low sulfur and ash content, Harlan coal was highly marketable; second, the absence of unionism permitted an uninterrupted operation of the county's mines; third, a lower wage scale, nonunion work rules, and lower freight rates gave the owners and operators of Harlan mines a distinct advantage over their northern competitors; and fourth, the presence of several, large captive mines whose entire output went to their parent firms. These factors, along with the absence of any type of competition from high-wage manufacturing employment, kept the Harlan field’s wages lower and more flexible than those of other coalfields.

During the early twenties, the UMWA remained a force to be reckoned with in the northern coalfields. In 1922, Harlan coal loaders earned 42 percent less than an Indiana miner, 24 percent less than an Ohio miner, and 5 percent less than a miner from Pennsylvania. Harlan operators enjoyed an additional cost advantage over their competitors: running time. In addition, the number of days worked in Harlan rose, from 105 days in 1922, to 259 in 1926 . At the same time, production and running time steadily decreased in northern union fields. Harlan County miners, the number of days worked 
and annual income increased between 1922 and 1929. Lower freight rates and wages, combined with the absence of strikes guaranteed the renewal of sales contracts. ${ }^{1}$ Thus, until the Depression, such advantages served both the operators and the miners well. In an industry where regular employment was rare for a number of reasons, Harlan miners did not want to do anything that might jeopardize it. This included union membership. As a result, regular employment encouraged miners' opposition to unionization of their field. Because of this, the county's first experience with unionism was "the product of government fiat." 2

The United Mine Workers enjoyed some earlier success in District 19. Harlan County was included in District 19, but mining in the county had begun in a nonunion era. In 1907, most of District 19's operators signed a contract with the UMWA, but the operators abrogated it in 1910. As a result, the district's membership, which had once numbered five thousand, dwindled to forty-eight by the eve of World War I.

The Great War created an increased demand for coal as well as a shortage of miners. These factors, combined with the encouragement of the Wilson administration, provided the union with a golden opportunity throughout the coalfields. Such an opportunity translated into the county's first, albeit brief, experience with unionism. In the spring of 1917, UMWA international organizers Van A. Bittner, William Turnblazer, Sr., David Robb, and William Feeney recruited fifteen hundred Harlan miners and organized them into three locals. Not surprisingly, Harlan's operators refused to recognize the union, and in August 1917, most of the county's mines closed down in response to strikes.

\footnotetext{
${ }^{1}$ John Hevener, Which Side Are You On?: The Harlan County Coal Miners, 1931-1939 (Lexington: University of Kentucky Press, 2002), 4-6.

${ }^{2}$ Hevener, Which Side Are You On? 6.
} 
Since any strike occurring during a time of war constituted a crisis, National Fuel Administrator Harry Garfield called the representatives of Harlan's operators and the union to Washington to negotiate a settlement. The operators stood their ground against recognizing the union, but they agreed to a wage increase, a shorter workday, election of checkweighmen, and establishment of mine committees to settle local grievances. On October 8, Harlan's miners returned to work, pending final agreement on wages and hours, and representatives from the union and operators' association signed a final agreement on November 1. Under the terms of the agreement, however, once the war ended, the agreement would as well. Nevertheless, by July 1918, Harlan's mines were organized with two exceptions: the giant captive firms of Wisconsin Steel Company (International Harvester's subsidiary at Benham) and U.S. Coal \& Coke Corporation (U.S. Steel's subsidiary at Lynch). ${ }^{3}$

The following March, District 19 miners elected S.A. Keller as their president. In 1919, District 19 was one of a small number of districts that were still full-fledged districts. Officials in full-fledged districts were not international appointees. According to miner preacher Jim Garland, who was a local union leader during the days of the National Miners Union in Harlan County, District 19 was one of only four full fledged districts to still exist by $1920 .{ }^{4}$ Keller, who had only been a union member six months prior to his election, proved to be a lackluster leader. Under his

\footnotetext{
${ }^{3}$ Hevener, Which Side Are You On? 5-6.

${ }^{4}$ James Garland believed that the use of provisional districts were John L. Lewis' way of "muzzling the rank-and-file.” See James Garland, Welcome the Traveler Home, Julia S. , ed., (Lexington: The University Press of Kentucky, 1983), 112. District 19 enjoyed its status as a full-fledged district until 1921 when Lewis appointed William Turnblazer as its president. That the district grew during this period and acted independently no doubt drew the ire of the autocratic Lewis. In 1920, a year after Keller's election, District 19 miners refused to endorse a contract that was negotiated by national organizer Van Bittner, because they believed that it only "paved the way" for the union's expulsion from the Harlan field. The miners quickly forced Bittner's transfer to Maryland, actions that surely fired the international president's anger against the
} 
administration, the district's treasury was exhausted. Without funds, the district would be not be prepared for the day when it faced off against the operators. ${ }^{5}$

On November 1, 1919, the union called a nationwide strike. When both sides agreed to arbitration by the Bituminous Coal Commission on December 12, the strike ended. Three months later, the commission awarded the miners a two-year contract that provided a forty-eight hour week and a 27 percent wage increase. In Harlan County, thirty-nine hundred union miners stopped 60 percent of the county's production and closed all major mines except those of Wisconsin Steel Company and the U.S. Coal \& Coke Corporation. Harlan's operators, who had no intention of extending a contract that they considered to be only a temporary interference in the operation of their mines, rejected the national contract and promptly removed the checkweighmen from their tipples and fired and evicted union miners. At the same time, operators raised wages four cents per ton above the union scale for loaders and thirty-five cents to one dollar per day above the union's daily wage scale.

When international organizer Van Bittner finally convinced the operators to sign a contract on August 13, 1920, the county's miners did not see this as a victory. Instead, they charged that such a contract only created an environment that would ensure that the union would be expelled from the Harlan field. This agreement was similar to the contract of 1918 in that it failed to cover corporations that were not members of the

district. In addition, while accounts of Harlan's union history mention District President Keller's ruination of the financial stability of District 19, this author found no evidence that document his mismanagement of the funds of District 19. Did this miner preacher exhaust the treasury or did Lewis order other officials in the district to set up conditions that would place the district's downfall on Keller? These events lead this author to speculate as to whether Lewis' stubborn resistance to repeated offers for assistance from William Turnblazer ,the jailed defendants form the Battle of Evarts, and various miners and their families had more to do with his need to "muzzle" the rank and file of District 19 than a lack of funds in the international's treasury. Edward Dean Wickersham, "Opposition to the International Officers of the UMWA, 1919-1913" ( Ph.D., diss., Cornell University, 1951), 192-193.

${ }^{5}$ Hevener, Which Side Are You On? 7-8. 
operators' association such as Wisconsin Steel, and U.S. Coal \& Coke, and Ford.

Furthermore, the contract only covered those mines where a majority of miners wished to work under it. Its most damaging provisions included the election of checkweighmen in open meetings at the mine mouth rather than by secret ballot in closed meetings at the union hall and excluded union recognition.

This contract also failed to give miners a raise in their wages. Instead, it called for a daily wage scale between thirty-five cents and a dollar lower than the prevailing Harlan scale. In essence, the contract did little more than offer the union a "remaining toehold” in the county. Thoroughly disgusted, the miners forced Bittner's transfer to Maryland. When the national agreement expired in 1922, miners who remained in the union went on strike but only managed to cut local production by 21 percent. Greatly weakened, the union was only able to sign a contract with the Black Mountain Coal Company. ${ }^{6}$

The miners were correct in their assessment of the 1920 contract. In 1924, Black Mountain abrogated its union contract, an action that sounded the death knell for the nine hundred member local union. When the agreement expired on March 31, 1924, the local union struck. The union held a rally on the courthouse square on the first of May. William Turnblazer, International secretary/treasurer Thomas Kennedy and Lawrence "Peggy” Dwyer, a field representative from Illinois gave speeches to an enthusiastic crowd that resulted in more than one thousand conversions to the gospel of trade union. Unfortunately, their victory would be short-lived. On September 1, the company fired, evicted, and eventually blacklisted forty-two union members, a number which included all the officers and committeemen of the local. Afterwards, the company surrounded its

\footnotetext{
${ }^{6}$ Hevener, Which Side Are You On? 7.
} 
property with fifteen private mine guards and resumed operation as an open shop. Many of the mine's former unionists left the county to find work, but a small number of them remained at the incorporated town of Evarts which was located near Black Mountain's camp. These men retained membership in UMWA Local 5355, a recruiting local without a single contractual relationship. To most observers, Local 5355 was a dying ember of coal. This single ember of coal would spark to re-ignite the labor movement in $1931{ }^{7}$ In spite of their lack of union representation, throughout the twenties, Harlan miners' were in an enviable position. Unlike miners in the northern fields, they generally prospered. While the miners in Harlan saw their daily wages and working conditions deteriorate, running time and annual earnings increased. These factors, coupled with the certainty of discharge, eviction, and blacklisting for union activity, were powerful bulwarks against union organization. More importantly, many union members had been particularly disillusioned with the contract that the UMWA and Van Bittner offered them in 1920. As Hevener adroitly points out, the psychology of the typical miner in Harlan County only reinforced their resistance to organization. Before the coal industry came to the county, these miners were struggling to survive on hillside farms. Thus, they were first-generation industrial workers who possessed independent spirits and had not yet accepted the idea of "permanent working-class status. Although life in a company town offered most mining families things that they could never have realized while living on the farm, many still hoped to return, someday, to their farms. Furthermore, these miners had little knowledge of the ways of the modern economic system and did not realize that, if the southern field continued to produce coal at the same, high rate, it would glut a coal market that was already saturated.

\footnotetext{
${ }^{7}$ Hevener, Which Side Are You On? 7-8.
} 
Harlan's miners failed to understand that overproduction would eventually bring unemployment and substandard wages to their own backyard. In 1929-1930, Harlan’s miners, as did the rest of the UMWA, supported the national regulation of the ailing coal industry. In spite of their support of governmental regulation, Harlan’s miners still did not attempt a sustained effort to rebuild their union, until it was almost too late.

Richard Callahan holds a different interpretation of the miners' irregular support of unionism throughout the twenties. Callahan sees such support as "episodic patterns of interest" that were related to a "cultural style” that was rooted in their religious traditions, particularly in the ways that mountain people viewed regular church participation and attendance.

According to Callahan, when viewed in "this light," organizational efforts of the UMWA can be compared to revival meetings and the union itself to an organized church:

Just as revival meetings gathered both sinners and saved, That is, those who had undergone the experience of conversion and those who had not- in periodic communal expressions of extraordinary worship, The organizational meetings of the UMWA took the form of revivals that attracted large numbers of miners to express their shared work experiences... Periodic revivals alone were sufficient for most people. They did not join a church. They returned to their daily lives not without religion but without feeling the need for sustained organizational worship.

When another revival took place, they likely took part... ${ }^{8}$

Equally important is the stance that the historian takes toward studies that blame the union's failure in areas such as Harlan on the "apathy among miners," declaring that their authors are guilty of the same methodological bias that led observers of mountain

\footnotetext{
${ }^{8}$ Richard J. Callahan, "Working With Religion: Industrialization and Resistance in the Eastern Kentucky Coal Fields, 1910-1932” (Ph.D., diss., University of California-Santa Barbara, 2002), 195-198.
} 
religion to conclude that low rates of church membership indicated a lack of religious interest. Union participation followed the same patterns as did religious revivals as thousand of miners took part in initial meetings but eventually drifted away from regular participation in union activities. ${ }^{9}$

Such an interpretation is a valuable contribution to the new paradigm proposed in this dissertation. Mountaineers and miners placed a great deal of importance on their religious beliefs and values. To them, it was more important to live their faith than it was to attend church on a regular basis. As it is with believers, regardless of socio-economic background, periods of crises usually drew them back to the fellowship of believers on a more regular basis-- at least for a time. Miners felt the same way about the union. They believed in the importance of labor unions and hoped and prayed that someday the union would establish more than a temporary toehold in Harlan County. Miners enthusiastically responded to the union's periodic calls to organize during times of trouble, but most miners rarely attended regularly scheduled union meetings after the crisis was over.

The good ole days of regular employment and good wages finally came to an end in Harlan County. The Depression, a warmer winter than usual, and the seasonal hiatus in the lake cargo trade severely depressed the coal industry. Any advantage that Harlan County's operators had enjoyed at the expense of their northern competitors was gone by the winter of $1930 .{ }^{10}$ The advantage was gone, but there remained in Harlan a glimmer of hope: Local 5355 at Evarts, miner preachers such as B.H. Moses, and international organizer Lawrence "Peggy” Dwyer who were permanent fixtures in the county

\footnotetext{
${ }^{9}$ Callahan, "Working With Religion," 195-198.

${ }^{10}$ Hevener, Which Side Are You On? 7-9.
} 
throughout the decade. B.H. Moses was most likely a member of a small, covert group of miners who continued to preach the gospel of Christ and trade unionism. Under the cover of darkness and unbeknownst to even those who worked with them, these committed unionists preached the gospel of trade unionism to individual miners, convincing them to join the union. Until they could be sure that there would be little risk of dismissal, eviction, or blacklisting, the union's leadership refrained from calling group meetings of any kind.

On February 16, Harlan operators cut wages by 10 percent, and irregular employment and reduced wages became the norm. As a result, miners and their families began to experience the same type of abject poverty that their peers in West Virginia and western Pennsylvania had been facing since the mid twenties. Most of the coal operators lent a hand by providing their unemployed miners with a dollar-a-day credit for food at the company store. Local relief funds were exhausted at the same time as the miners' need for relief peaked, and for the first time in its history, the county was forced to appeal to the outside for assistance. The national Red Cross tried to help, but its hands were tied since its funds were legally restricted to the victims of drought. Soon, the tension between miners and operators that had been simmering for more than two decades boiled over. The economic insecurity and the oppressive climate of company town life had finally pushed Harlan County's miners to the edge. ${ }^{11}$ Conditions, both in the camp and at the mine's face, had reached the crisis point, and the miners' conversion was at hand.

This was certainly apparent in Allen Talmadge’s description of the miners' conversion to unionism in the early thirties

\footnotetext{
${ }^{11}$ Hevener, Which Side Are You On?, 33; Tony Bubka, “The Harlan County Coal Strike of 1931” in Hitting Home: The Great Depression in Town and Country, Bernard Sternsher, ed., (Chicago: Quadrangle Books, 1970), 185.
} 
Camp environment was "completely degraded and getting worser and worser conditions till it got down to wher it [was] nearly unbearable. There had to be a change, there had to come a change. And when this change begin to take place, the moral and determined side of life, and the determination to have a better life... We don't have to live in no such conditions as this. Let's make our community, let's make our camp, let's make it a better place to live. You began to see churches spring up in the coal camps, and people began a-goin' out to church. They began to see the need of a better side of life, a better way of living. Because if they had hard timed, or if their families was starving, they were determined to help one another. It give them the determination, 'we're gonna stick together, we're gonna overcome this kind of life.' And they did. They did. I've seen it. I've seen it happen in my lifetime. I can clearly see the upgrading and a spark begin to flare up among people."

Callahan wisely points out that the preacher's narrative demonstrates the religious significance of historical events, "a religious significance that would be recognizable to those familiar with local cultural poetics but might be missed by those who looked for religion in other forms.”12

By the end of the winter of 1931, the effects of the Depression and a mild winter began to adversely affect the Harlan coal industry. Irregular work and reduced wages quickly took its toll on miners' families. The union had not been able to sustain the gains that it had made during the previous decade. The mighty hand of the HCCO and the everyday struggle of working and living in a coal town had squashed the union spirit. As the impending clouds of crisis loomed, UMWA district officials and local unionists seized this as an opportunity to re-establish the union in Harlan. Unionists had already begun a "clandestine revival” of the United Mine Workers Union. In early February, fifty-three miners attended a secret meeting in an abandoned mine entry at Black

\footnotetext{
${ }^{12}$ Richard J. Callahan, "Working With Religion: Industrialization and Resistance in the Eastern Kentucky Coal Fields, 1910-1932” Ph.D., diss. (University of California-Santa Barbara, 2002), 196-197.
} 
Mountain. ${ }^{13}$ Their purpose was to reorganize the union in southeast Kentucky, but every step had to be carefully planned. If the operators found out about their meetings, the men would be fired and blackballed from any mining job in the county. Chester "Red” Poore remembered the meeting and its leader W.B. Jones:

Jones was "the main man trying to organize... he handled the whole damn thing.... You'd be screened as you came to take your oath... One of the guys that went in the bunch turned out to be a thug here--carried the gun against us.

He took the United Mine Workers obligation same as I did, sure did. Everybody was welcome. Hell, you weren't screened too bad, but they'd screen you.

The miners continued holding meetings at various places. Finally, they decided to hold regular meetings in the woods in Pound Mill Hollow. Poore recounts one of those meetings:

We met here in the hollow one night...

Then it seems like we met down around Verda, Then the next night we met somewhere else. The next night was the big night at Pounding Mill... Great big place - could have been a corn patch, potato patch or anything. And one stump cut out, about as high as that chair.

[anyone standing on the] Stump, making him taller than everybody else...

They'd bring the meeting to order and tell you to gather up as close as possible, so we could hear every word he said, see... We'd all take the obligation same night, same time... You're supposed to stick by the union obligation, and that's it. ${ }^{14}$

By mid February, miners began seeking help from the international union.

Johnson Murphy, a black miner from Evarts, wrote John L. Lewis, asking him what the

\footnotetext{
${ }^{13}$ Hevener, Which Side Are You On? 33-35.

${ }^{14}$ Bill Bishop, “1931: The Battle of Evarts,” Southern Exposure (4: No. 1-2): 93.
} 
union planned to do for his wife and family "if they kill me for organizing.” For a while, it appeared as if the national was going to help the miners. The President of District 19, which covered southeastern Kentucky and eastern Tennessee, William Turnblazer and international representative Lawrence "Peggy” Dwyer issued a call in the February $15^{\text {th }}$ issue of the UMWA Journal, calling for the miners of District 19 to organize. In addition, Turnblazer distributed a circular in the fields that blamed the miners' hard times on "the insane policy of the coal operators in selling coal below the cost of production" and urged miners to organize and resist wage reductions, to abolish the cleanup system, elect checkweighmen, and improve living and working conditions. Turnblazer encouraged the miners to "fight and fight and fight against this terrible degradation that is being heaped upon you and your families.” Turnblazer also announced plans for a UMWA "rebirth meeting” in Pineville, on the first of March. The next day, operators proceeded to take an action that fueled their union conversion -- they announced a 10 percent wage reduction. On Sunday, March 1, more than two thousand miners from Bell and Harlan counties attended the rally in the Gaines Theater where they listened to UMWA vice president Philip Murray push for the reorganization of District 19.

The miners who stepped out in faith to attend the Pineville rally soon discovered that their commitment to the union was stronger than the international's commitment to them. The miners were ready to organize and strike for union recognition, but the international had no intention of supporting anything that extended beyond "a spirit of cooperation” between management and workers. In 1931, the UMWA was in a state of disarray after several years of enduring a depressed coal industry and rank and file pressure against John L. Lewis' autocratic leadership style. Lewis desired to make peace 
with the industry and control the miners. Thus, when Murray told the Harlan miners to go out and organize, he did not intend for them to "precipitate strikes." 15

The miners did not come to Pineville to hear pleas to organize with restraint, and W.B. Jones did not expect to be told to undertake a task that he had already accomplished. The miners were committed to the union, and they and Jones wanted visible support for the miners' commitment--relief aid and organizers from the international. Without it, the union would most likely be starved into submitting to the operators' demands to remain non-union.

The next morning, upon hearing the reports of company spies who had attended the rally, several Harlan firms began discharging and evicting employees who had attended the rally. Most of the discharged and evicted families moved to Evarts, one of the county's three unincorporated towns and home to UMWA Local 5355. In the next few days, increasing numbers of mine guards- known as "gun thugs" to the miners-- were hired and deputized by the Sheriff. In March alone, Blair swore in 26 new county deputies and 144 company employees, including the superintendent of Peabody’s Black Mountain mine. Peabody's home office also ordered the superintendent to institute the "yellow dog" contract system, a system in which miners had to promise not to participate in any kind of union activity in exchange for employment. Cash poor and heavily in debt to the company store, few miners could "turn tail and run." Thus, for most miners, the only choice that they had was to stand up and fight. For a time, the miners' continued the strike undaunted, despite disheartening responses to their letters from John L. Lewis, in response to requests for aid. Lewis 'standard reply to such letters contained the following:

${ }^{15}$ Bill Bishop, “1931: The Battle of Evarts,” 94-95 
"Under the laws governing the international union, there are no funds available for individual relief, and it’s therefore impossible for me to assist you.” A year later, W.B. Jones would receive a similar letter from the mighty John L. Lewis. ${ }^{16}$

By March, Jones, now the secretary-treasurer of the Black Mountain Local, was ready to demonstrate his local's resolve. On Sunday, March 15, 2700 miners and a few of their wives gathered on the school grounds in Evarts, marched across the Clover Fork, and down the road toward Verda. The peaceful march ended with 300 Verda miners taking the obligation, but the high point of the day came when Jones announced the date upon which the Black Mountain miners would walk off their jobs the following Tuesday, March 17.

Miners at the county's other fifty miners walked off the job as well, and Jones opened a UMWA office in the spare room of the house that he rented in town. To facilitate the creation of new locals, he created his own group of 12 to 16 organizers who worked in pairs, quietly behind the scenes, with leaders in non-union camps throughout the county. Poore said that Jones had "guys going everywhere...” even into Bell County, until they were "exactly like a damn octopus. We used to get into anything that opened." 17

In late March more than one hundred men were evicted from Black Mountain. Union leaders circulated a petition that asked Kentucky Governor Flem Sampson to remove the county sheriff and judge who enforced the union-busting tactics. By mid-

\footnotetext{
${ }^{16}$ Bill Bishop, “1931: The Battle of Evarts,” 94-95; John L. Lewis to William Hightower and W.B. Jones, 15 July 1932. William Hightower and W.B. Jones both wrote John L. Lewis from prison, asking that the union help their families, who were suffering financially. On July 15, Lewis wrote to them men and told them that it was "impossible" to assist their families and was sending their requests onto the International Executive Board, even though he had no idea when the next meeting was scheduled. Penn State University, Historical Collections \& Labor Archives, UMWA MSS, Box 88, fl 31.

${ }^{17}$ Bill Bishop, “1931: The Battle of Evarts,” 94-95.
} 
April 17,000 had signed the petition and marches with as many as 2500 marchers were commonplace. Rallies in front of the courthouse were hitting 4,000 by the end of April, and tensions were reaching the boiling point.

This time, operators had little hope of using racial animosity to break this strike. An integrated union had finally been established in Harlan. Both black and miners were united in wanting to see an end to the oppressive working and living conditions and seemingly endless stream of wage cuts and formed an integrated union. In spite of such a unity in purpose, this did not mean that they supported a union policy that called for an end to discrimination in housing and public facilities. As they had in most matters, black unionists took care of their own, and like white miners, they often "baptized" scabs in the creek. But when it came to union business, everyone had a voice. Holiness minister C.G. Green was a 30-year union man from Alabama and one of the regular black speakers at meetings in Harlan and Evarts. Tillman Cadle recalled one of these meetings in which Reverend Green was asked how a sheriff such as John Henry Blair could be elected by the people but be controlled by the coal companies. In response, the elderly man stated that a person can "go down to the store and buy yourself a piece of meat and take it home, you can cook it anyway you want to. You can boil it or fry it or cook it anyway you please because it's your meat. You bought it... That's the way the Sheriff is with the coal companies; they bought him and he's their meat." ${ }^{18}$

Union rallies continued to attract growing numbers of converts, but the international union maintained its policy of non-commitment. Any support for the strikers' actions threatened the coal industry and the United Mine Workers. The bankrupt union was unable and unwilling to contribute strike relief to a strike that it did not

\footnotetext{
${ }^{18}$ Bill Bishop, “1931: The Battle of Evarts,” 96-96.
} 
authorize. As any hope for national support faded, the frustration and violence erupted. A sniper's bullet wounded a mine guard at Black Mountain, union men publicly whipped and beat scabs, and mine entries were dynamited. In mid-April, a Knoxville NewsSentinel headline warned that a "Flare Up in Harlan Expected." Ten days later, a machine gun battle broke out between miners and a posse of deputies, and houses were burned and stores looted. On May 1, Jones was forced to establish armed patrols to guard Evarts’ businesses. ${ }^{19}$

Finally, on Monday, May 5, the violence peaked when three guards and a miner were killed in a thirty- minute gun battle just outside Evarts. At 9:30 a.m., three cars carrying nine mine guards from Black Mountain passed through Evarts on the way to Verda. They were escorting a new mine foreman to the Peabody camp. Union miners who had spotted the caravan earlier that morning, gathered around the Evarts depot and along the highway. Just as the caravan rounded a turn near the depot, a shot rang out and both sides opened fire.

For strikers, the May 5 battle was an important turning point. The outbreak in violence gave the operators an excuse to utilize the power of the local and state governments. In turn, UMWA officials were forced to either defend the strike, a strike that the national public viewed as a murderous and lawless uprising, or turn its back on its own rank-and-file. The international failed to waiver in its support of law and order. May 5 was the beginning of the end for this first, major battle in the workingman's revolution. ${ }^{20}$

\footnotetext{
${ }^{19}$ Bill Bishop, “1931: The Battle of Evarts, 99.

${ }^{20}$ Bishop, “1931: The Battle of Evarts,” 99.
} 
Two days after the battle, Governor Sampson sent the National Guard into Harlan with the written approval of Turnblazer and Dwyer. Under the terms of the agreement, the Guard was to disarm both miners and company guards. Within days, however, it became apparent that the agreement would not be fulfilled to the satisfaction of the union. Sheriff John Henry Blair refused to disarm his deputies, and the troops began to confiscate the miners' weapons. Local authorities also took steps to eradicate the union leadership with the arrest of W.B. Jones for the May 5 killings on the ninth. William Hightower took over the active leadership of the movement and made a series of speeches in Harlan and Bell counties to rally the unionists. Within days, he was also arrested for the killings. Eventually, forty-three miners were arrested on charges related to the battle, including the entire leadership of the local union. On May 11, Turnblazer and "Peggy” Dwyer met with Governor Sampson in an attempt to gain his support for a settlement that would substitute the open shop for the former nonunion shop. The agreement would provide for the reemployment of all discharged union members without discrimination, the removal of armed guards, the dissolution of outstanding injunctions, and the provision of food for starving miners and their families. For their part, the union would abandon its campaign, do everything in its power to end the growth of radicalism after the strike, and cooperate with operators on any program that would benefit both the industry and the miners. The Harlan County Coal Operators Association was clearly not interested in any type of cooperation with the union. In a later meeting arranged by the governor’s office between Turnblazer and R.C. Tway, a powerful operator and Republican state chairman, Tway refused to discuss the proposal with the union representative, let alone be in the same room with Turnblazer. ${ }^{21}$

\footnotetext{
${ }^{21}$ Hevener, Which Side Are You On? 48.
} 
Further evidence of the operators' consolidation of company and state power was demonstrated on May 12 when pickets stopped a furniture truck moving a strike breaker into Black Mountain only to have soldiers escort the vehicle into the camp. In order to re-establish order in the Harlan field and safeguard the newfound coalition of operators, district and international UMWA officials and local and state government entities, measures that would destroy the movement's ideological foundation followed on the heels of the waves of arrests and indictment. In a blatant act of betrayal, the international union took the first step. On May 15, the international announced that they were no longer supporting the organizing drive in Harlan and blamed the conflict upon "coal operators on who had allowed the IWW to get a foothold" in the field. In a separate editorial, the UMWA officially exited the Harlan field. ${ }^{22}$

On May 16, deputies raided Jones' house, where they found IWW literature, membership lists, application cards, and dues books. The sheriff's undercover agents reported that they had joined the UMWA in Jones' front room and had then been taken into a back room for initiation into the IWW. A Knoxville editor suggested that the sheriff planted the "evidence" to discredit the United Mine Workers union, an accusation that certainly had a great deal of merit since the IWW had been virtually defunct for more than a decade. ${ }^{23}$ Eventually, word that a well-known IWW member in the county turned out to be none other than one of the sheriff's paid informants, but the damage had been done. A week later, the UMWA convened a rally at the courthouse in Harlan. Deputies

\footnotetext{
${ }^{22}$ United Mine Workers Journal, 15 May 1931.

${ }^{23}$ Editorial, Knoxville News Sentinel, 17 May 1931.
} 
tossed tear-gas canisters from the roof of the courthouse to disperse the orderly crowd and the sheriff announced that no further rallies would be permitted. ${ }^{24}$

It would be six years before miners would feel free to assemble. The governor had turned his back on one of his last promises-- the union's right to assemble in daylight for organizational purposes- had been denied. Public support for the miners’ strike further deteriorated after Governor Sampson complained that "several undesirable citizens" from outside the state were in Evarts, "inciting and leading the trouble." His most damaging charge, that some of the county's unwelcome visitors belonged to “societies called 'Reds' and Communists,' and are opposed to the regularly constituted authority and to law and order," left miners who were already living on the fringe of the community, clinging to it by a few, worn, red threads. ${ }^{25}$ In his account of the end of the 1931 strike, John Hevener states that Sheriff John Henry Blair first initiated the "antiradical hysteria against the United Mine Workers and fastened upon the United Mine Workers an odium of radicalism and violence from which it required a decade to escape.”26 In reality, it was the union itself that did the fastening. The decline of the coal industry took its toll on the union's coffers and internal divisions further weakened the union. In the end, however, Lewis' decision to abandon the Harlan miners demonstrated the union's commitment to self-preservation at all costs.

Their hands tied, miners began drifting back to work. They had little choice, with their families starving, their leaders jailed and denied bail, their union labeled as radical, and their right to assembly and picket peacefully denied. By June 17, the strike was

\footnotetext{
${ }^{24}$ Hevener, Which Side Are You On? 50.

${ }^{25}$ Quotation in Bill Bishop, “1931: The Battle of Evarts,” 99-100; John Hevener, Which Side Are You On? 49-51.

${ }^{26}$ Hevener, Which Side Are You On? 50.
} 
declared dead when R.C. Creech Coal Company, the county's most thoroughly organized mine, resumed operations. When the last soldiers departed the county on July 23, all but 800 of 6,800 miners at seventeen mines were back at work. ${ }^{27}$ Between nine hundred and one thousand strikers refused to relinquish their union membership and sign yellow dog contracts, actions that put their names on blacklists where they would be refused employment and left to starve or leave the county. The strike was over, but the media was not ready to let it die. Ever hungry for stories that would boost readership, the media refused to acknowledge the war's end and continued to paint vivid pictures of the violence. Radical groups such as the IWW and Communist organizers wisely saw the miners' plight as an opportunity to add to their ranks. Thus, both IWW and Communist organizers were actively recruiting followers even before the final troops left in July. ${ }^{28}$ In mid-July, twenty-seven local National Miners Union members attended a Pittsburgh convention to help lay plans for another organizational campaign and strike in Harlan County. Although the miners were not ready for another strike, they were desperate for help from anyone who offered.

Long-time unionists knew that striking under such dire circumstances was futile. Besides, most miners had "had their fill of unionism and strikes." In spite of this, desperate men had little to lose, and miners in surrounding counties who had not yet revolted wanted to launch a second effort. The United Mine Workers Union refused the Harlan miners’ pleas for strike relief, offered only meager legal assistance to the victims of the first strike, and finally abandoned them altogether. In desperation, the miners turned to the National Miners Union, the UMWA's militant, Communist rival. As Tony

\footnotetext{
${ }^{27}$ Hevener, Which Side Are You On? 50.

${ }^{28}$ Hevener, Which Side Are You On? 50-51.
} 
Bubka notes in "The Harlan County Coal Strike of 1931," the significance of inadequate relief and its relationship to the Harlan strike is extremely important in the miners' willingness to support the National Miners' Union or any left-wing union that came to Harlan County to capitalize on the situation. ${ }^{29}$ For many miners, their loyalty to the United Mine Workers union was tenuous and dependent the union's ability to offer financial assistance. In spite of this, a small cadre of miners was resolved to seeing the union permanently established in Harlan County, but the miners were discouraged. For many of them, having to see the want in their children's faces was a new, gut-wrenching experience. Being helpless to do anything on their own to change their circumstances brought them to their knees. If they hoped for redemption, miners would follow the lead of any organization that would promise to help them out of their predicament. In 1931, the promise of food and relief was of paramount importance in encouraging miners to convert and transfer their loyalty from the operators to the United Mine Workers union. This required a great step of faith. When the UMWA abandoned them in the summer of '31, they were both desperate and devastated. Unfortunately, the worst was yet to come. In 1932, the coal depression hit rock bottom in Harlan County. Coal production plunged to 6,888,875 tons worth \$7.7 million dollars, one third of its value in 1929 . Miners were especially hard hit. Of the 11,920 miners employed in 1930, only 7,838 were working two years later. Miners who were fortunate to be working at all, worked only 156 days in 1932, for two dollars per day. Operators, who were losing money and watching mines close all about them, were in no mood to compromise and would not tolerate any labor agitation. Their ally in the sheriff's office, Sheriff John Henry Blair, had seen his hand strengthened by the public's outcry against violence and radicalism.

\footnotetext{
${ }^{29}$ Bubka, “The Harlan County Coal Strike,” 185.
} 
As John Hevener puts it, the UMWA was the "Union of the Damned" in the eyes of the coal operators and their supporters. ${ }^{30}$ In spite of this, hungry, desperate miners were ready to go to war on the side of any organization that promised to take them to the Promised Land.

Their great need for food and relief was, as Bubka points out, the most important factor that encouraged them to join left-wing unions that entered Harlan County to capitalize on their discontent. ${ }^{31}$ Their religion served several purposes during this period. In the beginning, their faith in God and the Bible reminded them to pray and trust that God would meet their needs and direct their paths. When the United Mine Workers, plagued by internal strife and limited funds, abandoned them, most of the miners believed that the arrival of the National Miners Union (NMU), a communist-backed union, was in answer to their prayers. The Communist Party had had little success in the United States before the Depression. The Communists vehemently disagreed with those who did not believe that unions could not be organized, let alone be engaged in strikes, during such desperate times and severely criticized the more cautious members of the party for exhibiting a lack of faith in "the growing radicalization and revolutionizing of the masses in the U.S.A.” ${ }^{32}$ The union had little chance of success in Kentucky. It did not have a local group of disciplined Communist party leadership in southeastern Kentucky, let alone a single functioning Communist party unit in the state of Kentucky at the time. In addition, there were never more than twenty local or outside trained party members operating in the field at any, one time, and the union's sizeable contingent of immigrant leaders bearing names such as Borich or Wagenknecht were at a decided disadvantage

\footnotetext{
${ }^{30}$ Hevener, Which Side Are You On? 55.

${ }^{31}$ Bubka, "The Harlan County Coal Strike," 185.

${ }^{32}$ Hevener, Which Side Are You On? 56.
} 
among the native born, population who were even suspicious of labor organizers from Pennsylvania. Nevertheless, NMU organizers were undaunted and arrived in late June, when the beleaguered and hungry miners were in the final days of their strike. ${ }^{33}$ Hunger, desperation, and the betrayal of the United Mine Workers Union made the Harlan miners open to the message of the NMU. This is evidenced in remarks made by holiness minister and coal miner Findley Donaldson in a meeting at Wallins Creek: "The National Miners Union is ready to handle it, to give you the same living conditions you had before the government put in these laws that were unjust. [He has in mind the Criminal Syndicalism statute which is the operators' easiest legal weapon against the formation of a union. See the chapter on legal terror.] The National Miners Union stands for the principles that our forefathers fought for us... I know that some time [sic] men will have to make a complete sacrifice; hundreds of men's lives will be sacrificed but nothing good ever came without somebody making a sacrifice... The National Miners Union is the only thing that has not failed us.”34

In mid-June, J. Louis Engdahl, chairman of the Communist relief auxiliary, the International Labor Defense (ILD), traveled to Harlan to offer legal help to Jones, Hightower, and the other defendants in the Evarts murder case, but the UMWA men declined his offer. In late June, a week after the Creech Coal Company resumed operations and the UMWA strike was definitely over, the first NMU organizer, Dan Slinger, alias Jessie Wakefield, and a young female field representative of the ILD, were sent to Harlan. They went at the request of a very small group of strikers who had been

\footnotetext{
${ }^{33}$ Hevener, Which Side Are You On? 56.

${ }^{34}$ Charles Rumford Walker, “Organizing A Union in Kentucky,” Harlan Miners Speak: A Report on Terrorism in the Kentucky Coal Fields Prepared by Members of the National Committee for the Defense of Political Prisoners, Reprint ed. (New York: Da Capo Press, 1970),48-49. Walker added the remarks enclosed in brackets.
} 
impressed with the militant rhetoric of the Daily Worker and who in early June had asked its editor to send NMU organizers. While National Guard troops were still in the county, radical literature, such as the Daily Worker, Southern Worker, and Labor Unity, was widely circulated. Most importantly, the NMU established seven soup kitchens, the most effective recruiting device for starving miners. By early July, ten local NMU unions had been formed.

Some of the most ardent social activists of the decade were miner preachers from the mountains and hollows of Appalachia. To them, leading the fight to unionize was a calling that was not unlike the one that they received to preach the gospel. They preached a simple message of salvation that was rooted in their deep faith in God and the Holy Bible. Their theology reflected the miner preachers' working class experience and deep belief in their right to interpret the Scriptures as led by the Holy Spirit. When they preached, whether the topic was on man's need for salvation or his need to demonstrate Christ's love and the brotherhood of discipleship through union membership, the words and phrases in their sermons and hymns reflected their simple, working class roots. They believed in the righteousness of their cause, and their fiery sermons had the power to pull the most stubborn sinner or scab to the altar of repentance. It is no wonder that miner preachers were in great demand as strike speakers. Some of the most radical miners to emerge as leaders during this period were holiness-Pentecostal miner preachers, such as Jim Garland, Jim Grace, and Gill Green. As previously discussed in chapter two, the leadership of holiness churches such as the Church of God (Cleveland) had struggled to reconcile their faith with their members' need to join labor unions, but few if any miners anguished over their decision to join the union. This was especially true as the miners' 
situation worsened. These men knew that going on strike would require them to commit actions that were both legally and morally wrong, but they believed that they had no other recourse. The operators had determined this course of events, as they slashed wages, hiked prices at the company store in order to compensate for falling coal prices, and hired increasing numbers of gun thugs. Thus, if miners committed such acts, they had been driven to it. The miners' reconciliation of their religious beliefs and desperation was summed up in a sermon that holiness preacher Findlay Donaldson gave at a union meeting at Straight Creek before the Battle of Evarts. The preacher's voice must have been heavy with heartache and desperation when he said, “...if you put a man in privation, you drive him to sin... if you give him something to live on, he can stand up to help the Christian world.,35

Holiness preachers were ready to lead their fellow miners into battle in order to gain a union and a contract. Jim Garland was a second generation miner preacher and unionist whose unionism ran back to his father's involvement with the Knights of Labor and the miners' strike in Coal Creek, Tennessee, in $1896 .{ }^{36}$ Although he was illiterate, Oliver Perry Garland was called into the ministry when he was only sixteen years of age. For years, Oliver preached at revivals that frequently lasted for weeks at a time. Since most churches held revivals during the harvest, he usually returned home with food, not cash. As did most preachers, Garland had to find a way to make a living, especially after he married and started a family. Garland became a farmer and operated a general store in East Bernstadt, Kentucky, and pastored the Missionary Baptist Church. When the miners

\footnotetext{
${ }^{35}$ Alessandro Portelli, The Death of Luigi Trastulli and Other Stories: Form and Meaning in Oral History (Buffalo: The State University of New York Press, 1990), 231.

${ }^{36}$ For more on the Coal Creek strike, see Karin Shapiro, A New South Rebellion: The Battle Against Convict Labor in the Tennessee Coalfields, 1871-1896 (Chapel Hill: University of North Carolina Press, 1998).
} 
went on strike in East Bernstadt, Oliver, his father, and uncle supported the strikers, an event that led to Oliver's downfall as a businessman. The storekeeper extended credit to the striking miners, and when they were unable to pay he went broke. After the store closed and work resumed in the mines, Garland initially resisted going to work in the mines and worked as a sharecropper, herb doctor, and veterinarian.

Oliver, also known as "Peoria," and his first wife, Deborah Robinson, had two children, Mary Magdalene, who later became known as “Aunt Molly Jackson,” and John, who died as an infant. After Deborah's death, Oliver married Elizabeth Lucas who gave birth to Jim and two other children. With six mouths to feed, Garland was forced to find additional work. Initially, he continued to farm and dig coal, but, money problems only worsened. Jim's mother told that him that when his father was sharecropping, the family had little to eat and the children often went about without the proper clothes.

During his sharecropping days, Oliver joined the Knights of Labor. Later, after he moved to Pittsburg, Kentucky, and began working in the mines, he joined an affiliate of the union. During the Coal Creek strike in 1896, the area coal operators hired local convicts to mine coal during the strike. Jim's father hid two prisoners for three weeks, until authorities abandoned the search. Once the search was over, union members set the convicts free. In time, his father taught himself to read by using the Bible and became an “excellent reader.” Eventually, Oliver Gardner joined the UMWA. From this point on, whether working in the mines or just living in coal camps as a preacher, Oliver Garland maintained his UMWA membership. During the boom years of World War I, Oliver Garland helped set up several new locals for the United Mine Workers. In time, his son 
Jim and daughter Molly would follow in their father's footsteps and make their own contributions to the union movement. ${ }^{37}$

The union's lack of support and exodus from the county led Jim, a miner preacher and member of the United Mine Workers Union like his father, to turn to the National Miners Union. By 1931, Garland was not sure that the NMU would have much success organizing the miners in eastern Kentucky. This was especially true of Harlan. Garland believed that three factors could ${ }^{38}$ make organizing efforts difficult: 1 . Thanks to improvements in roads and transportation, Harlan miners were more mobile; 2 . the largest operations were captive mines owned by large, powerful corporations; the miner preacher believed that it would be difficult to organize the judicious mixture of miners that remained working at Lynch.

Race would not be an issue on Straight Creek, an area where the NMU would see its greatest strength. This had not always been the case. Before 1921, Garland noted that many blacks lived along Straight Creek. Black miners joined the UMWA, and some were elected to local offices within the union. In spite of their success in the union, segregation existed above ground. Housing, schools, and churches were segregated. While Garland's father occasionally preached at black churches and opened his church to black preacher as well, this was not the norm on Straight Creek, or anywhere else in Harlan. The county's only race riot occurred in 1921, an event that preceded the black exodus from Straight Creek. A young, white man by the name of Girt Roarke started a fight with a black man over the object of both young men’s affections, a young, black girl. In the end, Roarke was shot and killed. When the boy's father found out, he went

\footnotetext{
${ }^{37}$ Garland, Welcome the Traveler Home, 26-34, 37-38, 102.

${ }^{38}$ Garland, Welcome the Traveler Home, 123.
} 
“berserk,” and began shooting at every black person he encountered, and soon`other whites joined in.

When members of the black community began to pour into Harlan Town, asking for help, the law refused. Many members of the community had been life long residents of the county, but those in authority evidently saw this as an opportunity to regain some of its former racial purity. Many black farmers left before they had the chance to sell their stock. Like many others, Al McFarland was forced to give his animals away to white neighbors. Within a week, all of the blacks had left Straight Creek, with most leaving all of their belongings behind. Only a few black miners continued to work at mines on the left fork of Straight Creek, but none lived along its banks. ${ }^{39}$

Straight Creek miners were in desperate straights in 1931. In spite of his concerns about the National Miners' Union, Garland, understood the miners’ desperation and supported the Communist union's plans to organize the county's miners. Finally, on July 15, NMU organizers Dan Brooks and Bill Duncan, along with Garland and Grace, led a twenty-seven member delegation to the NMU convention in Pittsburgh. Jim Grace described the desperate straits that the Harlan miners were in and the Red Cross and UMWA's refusal to assist them to convention delegates. Grace urged delegates to take their guns "out of their hiding places, and use them on the traitors and gun-men who represent our present form of government.. ${ }^{40}$ Frank Borich, the union's national secretary, promised relief to the striking miners and asserted that a strike would be called at the next convention. On July 22, the union issued a charter to the Harlan miners.

\footnotetext{
${ }^{39}$ Garland, Welcome the Traveler Home, 114-115.

${ }^{40}$ Garland, Welcome the Traveler Home, 114-115.
} 
By late summer, the union discovered that the poorer miners on Straight Creek in Bell County were most interested in joining the NMU, and for several weeks, the union led marches down both forks of Straight Creek and on into Pineville. A few, scattered picket lines closed down a few of the small number of working mines in the area, but no operation remained closed down for more than a couple of days. By late October, the arrests, acts of violence, searches, bombings, and raids had taken their toll. One Communist field organizer reported to New York headquarters that very little relief was being passed out to miners and that all but one of the soup kitchens had closed. The miners' locals were no longer holding meetings, and, for all intense purposes, the Communist party had ceased to function in Harlan County. ${ }^{41}$

In an attempt to bolster support for the union and a potential strike, the Communist party arranged for writer Theodore Dreiser, chairman of the National Committee for the Defense of Political Prisoners, and a committee of left wing writers and editors to visit Harlan County in November 1931 to investigate and publicize conditions in the eastern Kentucky coalfields. The committee interviewed various public officials, coal operators, striking miners, and members of the National Miners Union in Harlan and Bell counties. Their arrival earmarked the beginning of a "flood" of writers, theologians, students, and intellectuals to the area that lasted well into 1932. The Dreiser committee's visit generated a great deal of publicity for the NMU, but it did very little to alleviate the miners' suffering. Neither did their visits to miners' homes, church services, or rallies, result in many, new converts to Communism and the National Miners' Union. When the NMU issued the call to organize on the first day of 1932, of 4,000

\footnotetext{
${ }^{41}$ Hevener, Which Side Are You On? 57-58; Bishop, “1931: The Battle of Evarts,” 101.
} 
miners, only 83 responded. Conservative in both their politics and religion, few miners could support a union whose tenets included atheism and the overthrow of democracy. ${ }^{42}$

In time, however, their religious beliefs terminated their participation in the NMU. The leadership of the communist union assumed that, under their tutelage, the miners would react militantly against company oppression and reject certain aspects of their culture, namely their deep patriotism and religious beliefs. ${ }^{43}$ As Christians, they could not belong to a union that promoted atheism, adultery, communism, and, to a lesser extent, racial mixing. The leadership of the National Miners Union had under-estimated the importance of religion in the lives of miners. They erred in believing that class interests would outweigh the spiritual. To miners, the brotherhood that they enjoyed in a labor union was an extension of the brotherhood of Christ. Once they became aware of the atheistic stance of the Communist party and the National Miners Union, the miners parted company with the NMU. Although their earthly needs were great, they paled in comparison to their desire to remain faithful to their God. In the end, the National Miners Union and Theodore Dreiser, John dos Passos, and other intellectuals who visited the county in 1931 did more harm than good. As writers, Dreiser and Passos were fascinated with what the miners said in their speeches, sermons, and rousing labor hymns, yet they failed to truly listen to the messages. The miners did not use religious rhetoric just to convert miners’ to trade unionism or drum up support at rallies. They were religious people who could not support an organization nor do something that they considered sinful. Thus, most miners quit the union once they became aware of the union's

\footnotetext{
42 Bishop, “1931: The Battle of Evarts,” 101; Paul Taylor, Bloody Harlan: The United Mine Workers in America in Harlan County, Kentucky, 1931-1941 (Lanham: University Press of America, 1990), 27. 43 John Gaventa, Power and Powerlessness: Quiescence and Rebellion in an Appalachian Valley (Urbana and Chicago: University of Illinois Press, 1980), 115-116.
} 
affiliation with the Communist party. ${ }^{44}$ A miner who helped organize soup kitchens for the NMU remembered the moment that he became aware of the union's philosophy. He had gone to Pennsylvania, to help distribute some union literature. He sat down under a cucumber tree to rest. As he began reading some of it, he said, "Uh-oh, what have I gotten myself into." $\$ 5$

The coal operators and county officials perceived the miners' alliance with the communists' National Miners Union as a golden opportunity to pound the last nails into the union's coffin, and quickly made this the central issue. Those in power used the fear of communism to justify their refusal to issue relief to the families of striking miners, support the reinstatement of blacklisted miners, justify violations of the Constitution, and expel or jail radical organizers or their followers. As Hevener points out, the elite rationalized their actions as necessary for the preservation of social peace and civilization. In doing so, the operators, along with the sheriff, courts, the press, civic groups, veterans' organizations, vigilantes, and the United Mine Workers, all combined to destroy a radical movement. ${ }^{46}$ In the ongoing struggle for place, the miners lost, and the operators retained their hegemony. A line had been drawn, and the good people of Harlan were determined that no one would question its creation, including a group of clergymen whom they themselves invited to Harlan in May 1932.

A group of twenty-one ministers who had petitioned the United States Senate for an investigation were invited to visit the county to see conditions for themselves. On May 4-5, Reinhold Niebuhr, William B. Spofford, C. Rankin Barnes, and Cameron P.

\footnotetext{
${ }^{44}$ Alessandro Portelli, The Death of Luigi Trastulli and Other Stories: Form and Meaning in Oral History (Buffalo: State University of New York Press, 1990), 231-232.

${ }^{45}$ Bishop, "1931: the Battle of Evarts," 101.

${ }^{46}$ Hevener, Which Side Are You On? 57-58.
} 
Hall inspected a county mine and interviewed Bell County officials, social workers, UMWA leaders, ministers and miners. The group concluded that, in "an atmosphere of anti-Communism sentiment of hysterical proportions," county officials had approved the abrogation of civil liberties. The actions of ordinary citizens had not escaped the scrutiny of the clergymen, actions that revealed their inability to distinguish between "shades and degrees of radicalism.” When the groups urged that a congressional investigation might curtail the official sanction of lawlessness, local clergymen and officials accused them of religious modernism, a claim that would definitely undermine their credibility. ${ }^{47}$

Upon his return to New York, Reinhold Nieburh described his visit in an article published in the Christian Century ${ }^{48}$ While in Harlan, Niebuhr sensed that most of the citizens resented investigators who had descended upon the county. Such resentment was also aimed at Niebuhr's party of notable clergymen who had come to eastern Kentucky at the request of prominent business and church leaders in Bell and Harlan Counties. Locals resented the publicity that resulted from such publicized reports which grossly conditions and hurt the tourist trade. Niebuhr was aggrieved when he failed to hear citizens make any apologies for acts of violence that had rocked eastern Kentucky. Believing that they were acting only to preserve the county’s “purity, local citizens refused to offer up any apologies for acts of violence against miners or organizers. ${ }^{49}$ To the good citizens of Harlan, maintaining the status quo was more important than writing the wrongs inflicted upon the miners.

\footnotetext{
${ }^{47}$ Hevener, Which Side Are You On? 86.

${ }^{48}$ Reinhold Niebuhr, "Religion and Class,” The Christian Century 18 May 1932, 637-638.

${ }^{49}$ Niebuhr, Reinhold. "Religion and Class War in Kentucky, Christian Century, 18 May 1932, 637-638.
} 
The fallout from the Battle of Evarts, the appearance of the National Miners' Union, visits from investigators such as Theodore Dreiser and the discovery of "reds" in the county put an end to efforts to organize the miners in 1932. This left the rest of the community, both public officials and citizens, opposed to unions, even more so opposed to leftist, liberal-oriented organizations. As a result, the citizenry became increasingly intolerant of any future effort to organize the miners. Locals associated with the UMWA were linked to groups such as the National Miners Union, because of the violence and bloodshed during the 1931-1932 campaign. Most citizens agreed with William J. Cash’s equation: "labor unions plus strikers plus atheism plus social equality with the Negro equaled communists.” After 1932, Harlan became a closed society. Outsiders who dared to enter Harlan, risked personal injury, harassment, and intimidation. ${ }^{50}$ These events taught longtime UMWA loyalists such as B.H. Moses and William Clontz three valuable lessons, lessons that would have to be carefully heeded, if they were ever to realize the permanent establishment of the United Mine Workers Union in Harlan County:

\section{Lesson \#1}

Future organizing drives would have to be of the grass roots variety, led by locals, not outsiders. Outsiders included anyone coming from “afar,” outside southeast Kentucky. ${ }^{51}$ Lesson \#2

Future leaders must be God-fearing, patriotic men of impeccable reputation as defined by local consensus.

The convictions and sentences of life imprisonment handed down to William Hightower and five of the other defendants for their involvement in the Battle of Evarts

\footnotetext{
${ }^{50}$ Taylor, Bloody Harlan: The United Mine Workers in America in Harlan County, Kentucky, 1931-1941 (Lanham: University Press of America, 1990), 26-27; 33-34.

${ }^{51}$ Taylor, Bloody Harlan, 76.
} 
sent a clear message to miners: any future attempt to revive the organization in Harlan County would be declared an act of treason, a revolution, that would not be tolerated by the HCCOA and the good members of the community. To participate would mean, at the least, dismissal and eviction, and possibly, death.

If the miners were to ever be organized under the United Mine Workers union, it would have to be a grass roots effort, primarily led by local men without even a spattering of the red paint of communism. These would have to be men of good standing in the community, especially from within the mining community. Future leaders would have to hold the same values as both the mining community and the community at large: they would have to be god-fearing, patriotic, and fearless, qualities that would make it difficult for the coal operators and their middle class supporters to malign. Unionists also realized that it might be much harder to recruit new converts than it had been in the past. Thus, men exhibiting such attributes might possibly inspire miners to be willing to put their lives on the line to sign a membership card. It would also make it difficult for operators to discredit them, especially when it came to questioning their belief in God and their loyalty as Americans.

Participating in future organizing drives would require great strength and courage. As religious conservatives, most miners believed that strength and courage of this kind could only come from God himself, their ultimate Authority and Source of Power. They would not be able to look to the mainstream churches that were attended by the good people of Harlan. With their pews filled with local operators, mine managers, and their families and their offering plates full of company dollars, these churches gave little, 
if any, support to striking miners. Wanting a return to peace, prosperity, and order, the congregations and clergymen of the company churches turned their backs on the miners.

\section{The Perfect Solution:}

The third lesson that local unionist learned was that future organizers should come from the ranks of the county's preacher miners. These men should be the ones to stand in the front of the lines. They could use their ministerial status as part of the union's promotional strategy. Equally important were the additional resources at these men's disposal. Since the coal companies did not own their church buildings, their churches could serve as free spaces that could be used for local union meetings, rallies, relief centers. Most importantly, these buildings would act as free spaces where miners and their families could meet for encouragement and education on the righteousness of the union cause. 


\section{CHAPTER 7 \\ WE WILL MAKE YOU FISHERS OF MEN: \\ PREACHER ORGANIZERS AND THE UMWA}

Come now, you rich men,

Weep and howl for your torment has come upon you.

You have heaped up together treasures and the rust of them

shall eat your flesh as if it were fire.

You have held back by fraud the wages of those that labor in your fields and the cries of them have reached up to heaven against you.

\section{Reverend Oliver "Peoria” Garland ${ }^{1}$}

For miners, the day of reckoning had finally arrived. In June 1933, Congress passed the National Industrial Recovery Act (NIRA). Section 7 (a), of the act gave workers the right to join the union of their choice and to bargain collectively. UMWA President John L. Lewis, anticipating the enactment of section 7 (a) borrowed funds and committed the union's entire treasury to a massive organizing campaign. He told his organizers to act quickly "before the employers woke up to the fact that there were ways of getting around the law.” ${ }^{2}$ Lewis kicked off his campaign in the coalfields of western Pennsylvania in late May. One hundred organizers fanned out into the coalfields proclaiming the rights guaranteed under section 7 (a) and claimed that FDR wanted the miners to join the union. ${ }^{3}$ The majority of the operators in the soft coalfields had experienced tremendous losses when the wage, price, and market structure of the industry collapsed, and they were unable to mount an effective opposition.

\footnotetext{
${ }^{1}$ James Garland, Welcome the Traveler Home, Julia S. Ardery, ed. (Lexington: The University Press of Kentucky, 1983), 41.

${ }^{2}$ John W. Hevener, Which Side Are You On? The Harlan County Coal Miners, 1931-1939 ( Lexington: University Press of Kentucky, 2002), 94.

${ }^{3}$ James Gray Pope, “The Western Pennsylvania Coal Strike of 1933, Part I: Lawmaking from Below and the Revival of the United Mine Workers,” Labor History, 44 (No. 1-2, 2003): 15-16.
} 
Within weeks of the NIRA's enactment, the union had organized 92 percent of the nation's miners and UMWA membership rose from fewer than one hundred thousand to five hundred thousand. Only a few areas remained unorganized. Mines in Fayette, County, Pennsylvania, U.S. Steel Corporation’s Gary, West Virginia mines, various operations in western Kentucky; and the Harlan County field remained outside the protective fold of unionism. Anticipating that the UMWA would initiate a drive in Harlan County, the Harlan County Coal Operators Association (HCCOA) launched a preemptive strike. First, the association doubled the financial assessment on its membership in order to fortify its anti-union war chest. Next, on the eve of the NRA's enactment, the Harlan Association adopted a uniform field-wide scale and raised wages 10 percent. Only the Whitfield family’s two mines, Clover Fork and Harlan Collieries, rejected the new scale, which otherwise applied to twenty-eight of the thirty association mines and to eight thousand miners. ${ }^{4}$ U.S. Coal \& Coke was not a member of the association and had taken steps much earlier to safeguard its interests. Thus, operators were prepared for an all out war.

This was not the case for the miners. They had the legal backing of the federal government, but without the financial and organizational resources which only the international union could provide, the success of the first organizing drive of the New Deal Era would be short-lived. For the next three years, Lewis refused to authorize the funding of anything beyond a bare-bones campaign in Harlan, and a grassroots movement led by long-time unionists and miner preachers worked against all odds to

\footnotetext{
4 John Hevener, Which Side Are You On? The Harlan County Coal Miners, 1931-1939 (Urbana and Chicago: The University of Illinois Press, 2002), 94-104.
} 
keep the hope alive that someday the union would establish a permanent presence in Harlan.

Lewis’ position changed in 1937 when George Titler arrived in the county. First appointed as a field representative, Titler quickly rose to the presidency of District 19. With his meteoric rise in power, the flood gates opened, and the money poured into the union's efforts to organize the county. The international's change in strategy was no doubt precipitated first by Congress's passage of the Wagner Act in July 1935. This time, the various unions were cautious and waited until the Supreme Court approved the new labor policy on April 12, 1937. In the meantime, a subcommittee of the Senate Committee on Labor and Education, known as the LaFollete Civil Liberties Committee, manned by Senator Robert M. LaFollette, Jr., a progressive from Wisconsin, launched an investigation into violations of labor's civil liberties by employers determined to prevent the unionization of its workers. The committee focused upon Harlan County, and as a result of the probe and the operators' continued opposition to federal labor policy, the Department of Justice prosecuted sixty-nine operators and law officers for criminally conspiring to violate the Wagner Act.

The Fourth of July celebration of 1937 would be a dual celebration for Harlan County's miners. The following Sunday, on the seventh of July, miners gathered in Evarts to celebrate the law's enactment and to develop plans for reorganizing the county. Within weeks, organizers doubled the county's union membership to twenty-five hundred, and area newspapers and the union praised the role that this latest piece of New Deal legislation played in their success. At a Sunday afternoon rally in Evarts, international organizer, the Reverend Matt Bunch declared that union miners had "the 
arm of the United States Government” around their necks and encouraged miners to join immediately. George Titler concurred with the Presbyterian minister and proclaimed that the Wagner Act had "made Harlan County safe for Democracy.”5 Such success would have been much slower to materialize had it not been for the tireless efforts of those who had everything to gain and virtually nothing to lose- the miners and their miner preacher/organizers.

George Titler concedes that local leaders have not been given adequate credit for their contributions. In his book Hell in Harlan, Titler said that” too much credit could not be given" to the four preacher organizers that worked alongside him during his time in Harlan. ${ }^{6}$ Besides local preacher organizers Marshall Musick and William Clontz, Matthew Hollars, a Church of God (Cleveland) minister from Jellico, and Matthew Bunch, a Presbyterian minister from District 12 in Illinois, led the effort to organize Harlan in 1937. Although their doctrines were different, Titler declared that all four men "preached the same union doctrine" and had a "way of blending the emoluments of collective bargaining with the spiritual benefits of being a Christian.” To men such as these, "being a Christian" meant more than regular attendance at church. Instead, it extended beyond the walls of the sanctuary and into their homes, community, and workplace through loving and serving others. Like many of their fellow clergymen, these miner preachers received calls to the ministry. Yet, for men such as Musick, Clontz, Hollars, Bunch, and fellow preacher/organizer B.H. Moses, their callings extended to the labor union. Miner preachers were not the only men of God to be called to serve God as union leaders and organizers. Hamp Wooten was another miner who Titler credits with

\footnotetext{
${ }^{5}$ Hevener, Which Side are You On? 128-131; “Many Sign Up for Union’s Harlan Drive,” The Knoxville News-Sentinel 26 April 1937.

${ }^{6}$ George J. Titler, Hell in Harlan, (Charleston: BJW Printers, 1972), 141.
} 
being instrumental in bringing the union to Harlan, especially in the long-time nonunion fiefdom of Lynch. Although Wooten was not a preacher, he was a leader in the Church of God (Cleveland) in Lynch, and was the first president of Local No. 7425, the first U.M.W.A. local to have its headquarters in the city. Reverend Benjamin Harrison (B.H.) Moses

Benjamin Harrison (B.H.) Moses was born in Whitley County, Kentucky in 1900. Like most of his contemporaries, he started working in the mines well before he could vote. Moses became a miner at the age of fourteen, and three years later, he received the call to preach. Answering God's call to the ministry meant that he would follow in the footsteps of other men in the Moses family who were clergymen and prominent leaders in the Church of God Mountain Assembly. In 1895, J.H. Parks, a United Baptist minister, introduced the doctrine of sanctification to the McCreary/Whitley County area. It caught the attention of three other Baptist pastors in the area: Steve Bryant, Tom Moses, and William Douglas, who were affiliated with the local South Union Baptist Association of the United Baptist Church. For the next eight years, these pastors preached the "most un-Calvinistic doctrine" and won many Baptists. The Baptist Association regarded the holiness doctrine-- that a person could live a sinfree life-- as heresy, and the movement's growing number of Baptist converts finally led the association to summon Parks and his followers to appear before from the association to be tried for heresy. The charge against them was that they taught that "men could be lost after regeneration," a serious heresy to predestination Baptists. At their hearing, the association found the men guilty, expelled them from the association, and revoked their ministerial credentials. After the trial, five Baptist churches left the denomination, in 
sympathy with the holiness leaders. By 1906, these churches met in a General Assembly at the Jellico Creek Church in Whitley County and organized a new denomination that they called "The Church of God.” Several years later, the mountain group, after being told that other denominations were using the same name, added the words "Mountain Assembly” to distinguish their name from the others. ${ }^{7}$

The tenets of the Church of God Mountain Assembly and the Cleveland Assembly were similar, and in the early years the two groups enjoyed a close relationship that nearly resulted in a merger. Ministers from the two groups were frequent visitors and guest speakers to one another's General Assemblies. At the Mountain Assembly's sixth annual assembly, a motion was made to send a letter to the Cleveland Assembly, asking them to receive their messengers or representatives at their General Assembly that was to be held the following January in Cleveland, Tennessee. The Cleveland group agreed. Once the Assembly convened, General Overseer A.J. Tomlinson introduced J.H. Parks and S.N. Bryant to speak to the delegation concerning a union of the organizations, and a committee was appointed to work out plans for the consolidation. While the delegates were still in Cleveland, they accepted the committee's terms and the Cleveland group extended the right hand of fellowship to the men, but the merger of the two organizations never took place. While the exact reasons why the Church of God Mountain Assembly never finalized the union are not known, Mountain Assembly minister and historian Michael Padgett suggests two possible theories. His first theory deals with the conditions of union such as recognized tenure and status that some of the leaders of the Mountain Assembly may have found objectionable. His second theory

\footnotetext{
${ }^{7}$ Vinson Synon, The Holiness-Pentecostal Tradition: Charismatic Movements in the $20^{\text {th }}$ Century, $2^{\text {nd }}$ ed. (Grand Rapids, MI: William B. Eerdmans Publishing Company, 1997), 69-70.
} 
deals with the teachings of the Cleveland Church of God, teachings that certainly were troublesome to the vast majority of the ministers and lay members of the Mountain Assembly in Tennessee and Kentucky: the church’s teachings against union membership. As has been previously discussed, the Cleveland group's doctrine allowed its members to become dues paying members of labor unions if it was a condition of their employment, but they forbade their members to participate in meetings or other union activities. In 1912, the church would neither license nor ordain any minister connected to a labor union. If the Mountain Assembly agreed to support this tenet, the credentials of most of its ministers would be nullified. ${ }^{8}$

Like many mountain preachers, B.H. Moses worked in the mines during the week and preached on Sunday. B.H. first joined the United Mine Workers Union in 1917, shortly before he moved to Harlan County. Until he was killed in a roof fall in 1939, Moses preached the Gospel of Christ and trade unionism and tirelessly worked to establish the union in Harlan County. His testimony to the LaFollette committee in 1937 indicates that he was most likely a member of a small circle of miners who continued organizing under the cover of darkness during the twenties and thirties, after the international withdrew its support. When asked if he was a member of the United Mine Workers Union, Moses told the committee that "I first joined in 1917 in Whitley County, and I was a member until the last local union went down in 1924 in Harlan County. I rejoined in 1927 and was a member during the campaign there to try to organize, and

\footnotetext{
${ }^{8}$ Michael Padgett, A Godly Heritage: A History of the Church of God, Mountain Assembly, Inc. (Kearney, Nebraska: Morris Publications, 1995), 20-23.
} 
when it failed, I did not pay dues anymore until 1933 . When the N.R.A. was signed, I joined again. ${ }^{9}$

In 1928, Moses began working for the Clover Splint Coal Company. While working for the company, he and his family lived in the company town of Closplint where he also served as the pastor of the Closplint Church of God. In July 1932, the company fired Moses for refusing to work on Sunday and placed him on the blackballed list, an act that temporarily prevented him from obtaining work as a miner. Because of this and his family's subsequent eviction, he was forced to resign as pastor of his church. At this time, the congregation of the Black Bottom Baptist Church invited B.H. to become their pastor. Black Bottom was a tiny community located only a half mile from the coal camp of Closplint. After agreeing to become their pastor, B.H. and his family moved into some rooms adjacent to the church's sanctuary. During the four years that Moses worked for Clover Splint, the company had successfully kept the union out of its operations. This would change with the passage of the N.I.R.A. in June of the following year.

The UMWA began its organizing campaign on June 1. By the first of August, the union had signed up the majority of the nation's miners, even in Harlan. In an attempt to thwart efforts to organize a U.M.W.A. local at its mine, the superintendent at Clover Splint held a meeting at the mine and tried to start a company union, without success. A delegation of miners immediately went to Jellico to meet with William Turnblazer who advised them to sign up the rest of the men without delay. Following the district president's advice, the men returned and established a U.M.W. local at Clover Splint

\footnotetext{
${ }^{9}$ U.S., Congress, Senate, Subcommittee of the Committee on Education and Labor, Violations of Free Speech and Rights of Labor, $75^{\text {th }}$ Cong., $1^{\text {st }}$ sess., 1937,Part 10. Testimony of B.H. Moses, 3495. Thereafter cited as LFCH.
} 
shortly after the President signed the N.I.R.A. into law on June 16. Although Moses no longer worked at the mine, several miners visited Moses and asked him to join their local. Reverend Moses reminded them that he was no longer working as a miner and had been discharged from the mine, but they were not dissuaded. Moses, as a long-time union man, agreed to join their local and offered the local the use of his church as a meeting place. Once the local was established, the preacher began to work with the local, signing up other miners. That a well-respected man of God provided the free space and support necessary to maintain a successful organizing drive did not go unnoticed by the coal company. Soon after he resumed his union activities, the company sent the Moses family and the church at Black Bottom a clear message regarding their support for efforts to organize its miners in the form of four sticks of dynamite.

This first attempt on Moses' life took place shortly after he returned home from a short trip. As he caught up with the comings and goings of his family while he had been away, one of his daughters continued to play in the church. While playing, she found a "greasy bag.” The little girl thought that the bag contained some meat and ran to get her father. When the preacher opened the bag, he discovered that it contained four sticks of dynamite with fifty feet of fuse that had burned within eighteen inches of the cap. Moses believed that someone had attempted to bomb the church because the union had held a mass meeting in the church building on the previous evening. The meeting was supposed to have taken place outdoors, but when it rained, the local moved the meeting to the church. That night, someone planted the dynamite inside the building. Fortunately, the fuse burnt out, well before the flame reached the cap. ${ }^{10}$

\footnotetext{
${ }^{10}$ Testimony of B.H. Moses, LFCH, Part 10, 1937, 3496-3497; Telephone conversation with Mildred Moses, 3 June 2005.
} 
When Moses notified Sheriff Blair, the Sheriff's only response was that he was sorry that Moses had touched the dynamite and ruined the chance of obtaining any fingerprints. A few days later, Moses met Allen Bowlin, the deputy sheriff, in Harlan town. Bowlin asked the preacher to meet him in city hall. Moses' first thought upon hearing the deputy's request was of a similar meeting that had taken place in city hall some time earlier. In this instance, a union man was invited to a meeting at city hall, and when he entered the building, he was gunned down. When Bowlin assured Moses that no one else would be there, he agreed to the meeting. When the meeting took place, the deputy told Moses that he needed to leave, because "two companies" were planning to have him killed because the preacher was "giving them more trouble than all the rest of the men.” At the time, Moses was living between the Cornett-Lewis and Clover Splint Coal Companies. According to Bowlin, gunmen planned to kill Moses in the next eight hours, in a place where no one else would be harmed. However, the deputy refused to name the companies. Moses told Bowlin that he had no intention on leaving, but would stay away from home with a friend. Upon hearing this, the deputy advised him not to let anyone know where he would be staying. After the meeting, Moses told the man who had driven him to city hall to tell his wife that he would not be returning home that night and went to another camp for the night. While Moses was gone, his church hosted a political rally for the New Deal candidate for judge, Morris Saylor, who had been personally endorsed by the preacher and the union.

Earlier that spring, Sheriff John Henry Blair had fired eighty-six deputies at more than thirty coal camps where the operators had refused to support his run for the chairmanship of the county's Republican Party. To the God-fearing miners of Harlan 
County, the reduction in the number of deputies at the very same time that the NIRA guaranteed them the right to organize and engage in collective bargaining must have been seen as answers to prayer. Miners and union leaders were also hoping to take advantage of other changes in the political arena as well. The winds of change generated by FDR's New Deal administration had made their way to Harlan County, and a slate of New Deal candidates promised to bring reform to Bloody Harlan. The terms of current, county office holders were scheduled to expire on December 31, 1933, and the political outlook for the union beyond this date certainly looked promising. In the fall of 1933, a slate of reform candidates entered the Republican primary pledged to a New Deal for Harlan County. This primary held a special significance to miners since the Republican incumbents had long been known for their anti-union sentiments. Theodore Roosevelt Middleton, the police chief of Harlan, was running for sheriff. Middleton had won the support of miners during the summer of 1933, when he roped off city streets in Harlan City for union parades and rallies and protected participants. The union had also endorsed Elmon Middleton for county attorney, James Gilbert for circuit court judge, and Daniel Boone Smith for commonwealth’s attorney. As reform candidates, they promised to reduce the county's homicide rate, to reform the private guard system, and, most important to miners, to provide equal protection under the law for union members and organizers. ${ }^{11}$

Before the election, several candidates made specific promises and took actions that led miners to believe that life in Harlan County would be much different under their tenure. The candidates for sheriff and judge, whose duties included the appointment and confirmation of deputies, promised to no longer reappoint deputies such as Unthank,

\footnotetext{
${ }^{11}$ Hevener, Which Side Are You On? 98-100.
} 
Fleenor, White, and Lee, whom the union found objectionable. Morris Saylor was a 38year old merchant from Molus and a political newcomer, running against Sheriff Blair for county judge. For the family of B.H. Moses and the other mining families who attended the Black Bottom Baptist Church and the nearby Closplint Church of God, their support for the union and its choice for county judge came with a price. ${ }^{12}$

Mildred "Weets" Moses remembers her father as a "beautiful man who loved his family and was loved by many others as well.” In spite of his devotion to his family, Benjamin Harrison Moses’ call to serve God and man as a preacher and union organizer meant that he was frequently forced to stay away from his loved ones in order to ensure their safety. ${ }^{13}$ Such was the night that Moses partially heeded Deputy Bowlin's advice and stayed at the home of a friend who lived in another camp.

While Moses was in Harlan Town, Morris Saylor visited the preacher's home and asked Mrs. Moses for permission to hold a political rally in the church that very evening. B.H. had been campaigning for Saylor but was not aware of the plans for that evening's meeting. Mrs. Moses gave the candidate permission to hold the meeting in the church that evening. Later that evening, as the candidate was coming to the end of his speech, someone in the audience noted the odor of a burning fuse and quickly issued an alarm. Mr. Saylor and several attendees dove through a nearby window while others exited through a glass door. Fortunately, the fuse failed to go off this time as well as a small piece of fuse was found in a nearby ditch. When recounting the incident for the LaFollette committee, Moses stated that he believed that the person responsible for setting the fuse ran upon seeing the crowd's anxious exit from the church. In the end, the

${ }^{12}$ Hevener, Which Side Are You On? 99-100.

${ }^{13}$ Telephone conversation with Mildred Moses. 
injuries were slight. A few individuals suffered cuts to their hands when they

accidentally ran their hands through the glass in the door and another man had a finger smashed when a window fell on his finger as he dove through it to safety. ${ }^{14}$

Two days after the incident at the Black Bottom, Allen Bowlin once again warned Moses of plans to take his life. On the following Friday, Moses ran into the deputy and his wife in Harlan Town. As they passed one another on the street, Mrs. Bowlin quietly walked up to the preacher and told him to meet her husband in a nearby furniture store. The deputy was surprised that Moses was still in the county and reiterated the coal operators' plans to have him killed. Moses, while not expressing surprise at their determination, did wonder what he had done that necessitated such plans.

With his business in Harlan Town complete, Moses returned to the Black Mountain camp and remained there for a few days before returning home. On the morning of his return, a woman came into the Moses' home, distraught. In tears, she told the preacher that her husband had sent her, to warn him of an impending plan to murder him. According to her husband, several of the preacher's friends had been lying in the weeds that surrounded his house during the night, watching over him and his family. Finally, things had gotten "so hot," that Moses' friends and fellow unionists told the preacher that that he would be wise to "get away for a while." Moses took their advice and went to his former home in Whitley County, where he remained for a week. Since he wanted to be in Harlan for the election, Moses took a chance and returned home to help with the election, hoping that he could help "elect the man that promised the equal

\footnotetext{
${ }^{14}$ Testimony of B.H. Moses, LFCH, Pt. 10, 3500-3501.
} 
protection in the law and equal rights for the citizens in Harlan County.” To Moses, this meant everyone, regardless of occupation, class, or religious beliefs. ${ }^{15}$

During any other time of the year, most of the good people of Harlan cared very little about the views of coal miners, but this changed during an election year. Since miners made up a major part of the electorate, their support was crucial to any candidate's campaign. During the initial phase of the primary campaign of 1933, Moses had not yet thrown his support to any of the potential candidates for county judge. When a man by the name of Stokes asked the organizer which candidate the miners intended to support, he told him that while he had not yet decided. Moses told Stokes that he "was for the man that it took to beat John Henry Blair regardless who it was.” While in Harlan Town a few days later, Stokes once again approached Moses concerning the issue. A man by the name of Ayers, who was a barber in Harlan town, soon entered into the conversation between the miner preacher and Stokes. The preacher believed that the barber would be a good source of information regarding the "general rumor" of the public towards the upcoming election. When asked about his patrons' views of the candidates for county judge, Ayers told Moses that most of his patrons supported Morris Saylor. ${ }^{16}$ It soon became clear that Stokes knew what the outcome of the discussion would be all along, because, upon hearing this, he asked Moses to go to the merchant's home. The preacher miner agreed and accompanied Stokes to the Saylor home. Once the introductions had been made, Stokes left and the two men began to discuss the up andcoming election. Moses had two issues to consider before he could consider supporting the political newcomer for judge. No doubt, Saylor expected one of those issues to be the

\footnotetext{
${ }^{15}$ Testimony of B.H. Moses, LFCH, Pt. 10, 3500-3501.

${ }^{16}$ Testimony of B.H. Moses, LFCH, Pt. 10, 3500-3501.
} 
lack of legal protection afforded to minors. His first concern, however, concerned the treatment of Holiness people whose churches did not receive the same kind of protection given to other churches in the county. Holiness-Pentecostal churches had been the target of frequent attacks since the turn of the century for their emotional services, speaking in tongues, and strict standards of behaviors. Holy Rollers were controversial, and their ways were not accepted by most Christians. They were commonly persecuted, with holiness-Pentecostal preachers and believers teased, sworn at, assaulted, and sometimes the targets of shootings. While the reasons behind such extreme reactions are unclear, Richard Callahan believes that believers' claims of sinless-ness and their physical displays disgruntled many members of their communities. ${ }^{17}$ Whatever the reason, Holiness churches frequently had their services disrupted by drunken revelers or law enforcement officers investigating reports that of their services disturbing the peace. ${ }^{18}$

While no official record of reported attacks upon holiness churches in Harlan has been uncovered, a previous resident of Lynch recalls that the community exhibited a good deal of animosity toward Holiness-Pentecostal followers. Mrs. Bennie Wilder, whose older sister and two female cousins were among the charter members of the Lynch Church of God in 1930, claims that neither the coal company nor many of the townspeople wanted such a church in their town. When members of the future church first began meeting, they held worship and prayer services in various homes in Lynch and frequently received visits from the coal company's police force who asked them to stop

\footnotetext{
${ }^{17}$ Richard J. Callahan, "Working with Religion: Industrialization and Resistance in the Eastern Kentucky Coal Fields, 1910-1932” (Ph.D., diss. University of California, Santa Barbara, 2002), 178-179.

${ }^{18}$ During a family reunion in July 2003, the author heard stories about her paternal great grandmother, Mary Harvey, who was a member of a Holiness-Pentecostal church in Kitzmiller, Maryland at the turn of the twentieth century. In one account, her great-grandmother and several others in the congregation were jailed for disturbing the peace; Telephone conversation with Bennie Wilder 7 March 2006.
} 
making such a commotion. Without insulation, the thin walls of coal company houses, even those in the model town of Lynch, provided no barrier against noise. ${ }^{19}$

Moses no doubt knew that he had a good chance of gaining the support of the candidate on this issue, since, as Saylor related to the preacher, most of "his people were of that belief.” He then promised Moses that, if he was elected, “a man was guilty of disturbing the church, that he would fine him to the extent of the law regardless of what church it was.” The miner preacher's subsequent question concerned the labor situation, a situation, claiming that the miners had never "had an even break with the coal operators.” Although they did not own their homes, Moses reminded the judge that miners were still taxpayers and citizens who should enjoy the same rights as others in the county. Saylor had been a merchant in nearby Molus for several years and supporter of the miners during strikes in that community. The discussion then turned to the subject of the appointment of deputy sheriffs in the county. As a judge, Saylor would have the responsibility of approving the appointments of deputy sheriffs. With Saylor's promises to afford both miners and Holiness people equal protection under the law and refuse to approve the future appointments of any deputies currently serving in the county, Moses promised to support the man's run for judge. $^{20}$

A few days later, Saylor stopped at Moses home. While there, Moses told the candidate that several miners had questioned him regarding the merchant's support of coal operators who had asked him to sign a bond for a man who had applied for a mine guard in a nearby county. Saylor denied signing the man's bond and asked the organizer to accompany him to Pineville where he could obtain a certified copy of the man's bond

\footnotetext{
19 Telephone conversation with Bennie Wilder 7 March 2006.

20 Testimony of B.H. Moses, LFCH, Pt. 10, 3500-3501.
} 
to prove that he had not signed it. Moses agreed. On the way to Pineville, Moses stated that the two men discussed the deputy sheriff situation, where once again, the candidate for judge promised not to reappoint any of the present deputies on the list if he was elected. ${ }^{21}$ Reverend Moses believed that he was campaigning for a candidate who truly wanted to reform the system. Unfortunately, Moses and the miners would find out that they had sadly misplaced their trust.

The Clover Splint local discontinued its meetings at the Black Bottom Church after the Saylor rally. Reverend Moses and his family remained at the church until shortly after the August 5 election. When Moses obtained employment with the Black Mountain Coal Corporation, he moved his family into a company house in Kenvir. Upon his arrival, he established a church that would become part of the association of which his family helped to found, the Church of God Mountain Assembly.

The mining camp of Kenvir was home to Black Mountain Coal Corporation’s mining operations, the only operation that remained under union contract at the end of 1935. The community should be remembered as a leader in social justice for another reason: the Kenvir Mountain Assembly (Colored) broke the color barrier in the Church of God Mountain Assembly. The Black Mountain Coal Corporation employed a large number of African American miners during the 1920s, a decade in which the Ku Klux Klan figured prominently in Harlan County. When B.H.Moses founded the Kenvir Mountain Assembly in 1933, his church was not the first Church of God, Mountain Assembly in Black Mountain Coal Corporation’s company town. The first church associated with the Mountain Assembly group was officially received into the Assembly’s fellowship in 1924. This church, known as the Kenvir Mountain Assembly

${ }^{21}$ Testimony of B.H. Moses, LFCH, Pt. 10, 3500-3501. 
(Colored), and was started by the Reverend E.D. Johnson. A year later, Reverend Johnson became the first African American to preach at a General Assembly when he was invited to speak at the Mountain Assembly’s 1925 general meeting. The Kenvir church did not remain in the organization. Two years later, the church joined the Cleveland group, and Johnson started a "colored work" in the community of Kildav, a mining camp owned by the King Harlan Coal Company. ${ }^{22}$

Reverend Moses was a busy man and saw his ministry to both the church and the union increase during the next, six years. By day, he continued to work as a miner for the Black Mountain Coal Corporation in Kenvir, and participated in union activities as an organizer and officer in Local No. 6659. In the latter part of the decade, B.H. served as the president of his local union. On nights and weekends, Moses tended to the needs of his growing family, church, Sunday school, and the national organization of the Church of God, Mountain Assembly. After he established his church in Kenvir, he became an active member in the national organization of the Mountain Assembly. He served as a member of the Board of Elders between 1925 and 1929 and was a featured speaker at the General Assembly in 1927, 1931, 1934, 1936, and 1937. Other members of the Moses family figured prominently in the organization. Two of his uncles, Kim and Ira, served as assistants to the General Overseer and General Trustees and served on the Board of Elders and Resolution Committee. Kim Moses also served as the Kentucky State Overseer. $^{23}$

The miner preacher's life was cut short on February 11, 1939, when he was killed in a roof fall in Mine No. 31. Moses was working the day shift when the roof fell at

\footnotetext{
${ }^{22}$ Michael Padgett, A Godly Heritage, 32-33.

${ }^{23}$ Michael Padgett, A Godly Heritage,32-33, 41-43, 108-109, 118-123, and 127.
} 
about 10:00. The falling slate struck and killed him almost instantly. The veteran miner, preacher, and union leader was only forty-eight years old at the time of his death. ${ }^{24}$

\section{Reverend Marshall A. Musick}

In addition to Reverend Moses, another man of the cloth was involved with the Cornett-Lewis local, the Baptist miner preacher Marshall Musick. In time, Musick was wounded twice, his son murdered, and he became known as the most harassed organizer in the county.

Marshall Musick had been a Lay minister for the Missionary Baptist church for more than a half dozen years when he moved to Harlan County in 1923 to find work in the mines. ${ }^{25}$ Reverend Musick worked at various mines in both Bell and Harlan Counties until his employment with the Cornett-Lewis Coal Company in the early months of 1933. In the spring of the same year, the union organized the miners at Cornett-Lewis, and Musick became the local's first financial secretary. When he first began working at Cornett-Lewis, the miner preacher was employed as a coal loader, but his position changed to checkweighman after he became the local president.

Until the contract between the union and the coal operators' association went into effect on October 2, the local union met off company property, at first, meeting at the Black Bottom Baptist Church. After the thwarted bombing of the church, the local moved its meetings to the nearby Closplint Church of God. Within days, the church was destroyed by dynamite. Debbie Spicer was twenty-six years old when the church was destroyed. She knew the Musick family quite well and remembers the day that the church was destroyed.

\footnotetext{
24 “Slate Fall Fatal to Kenvir Man,” Harlan Daily Enterprise 12 February 1939.

25 Testimony of Marshall Musick, LFCH, Pt. 10, 3452-3453.
} 
Debbie Spicer was born into a farming family near the town of Evarts in 1907. When the mines came, her father began working as a construction worker around the mining operations. He worked on the construction crews that built the coal tipple and commissary at Louellen. Spicer met her future husband when he was working at the mine and living in Louellen, and she lived in nearby Clover Splint where her family owned a farm. She was only sixteen years old when they were married in 1923 and "went to housekeeping" at Louellen. All three of the Spicer children were born at home. The Musicks lived near the Spicers in Louellen, and Mrs. Musick was with Mrs. Spicer when she gave birth with her daughter Pauline.

As a child, Debbie attended the Baptist church. Later, she began attending a holiness church, most likely the Closplint Church of God and knew both Musick and B.H. Moses. She recalled the dynamiting of the Black Bottom Church and attributes the failure of those who set the dynamite to God's protection:

You can't destroy a child of God as long as the Lord's got something for him to do, you can't do nothing with him. They didn't do nothing with Daniel, they put him in the lions' den but the lions wouldn't eat him, they just laid down... [the dynamite] didn't blow brother Moses up. Didn't even singe the hair on their head. Brother Moses was a real man of God, he's a real preacher. ${ }^{26}$

Mrs. Spicer recalls that Reverend Musick was a "good preacher" as well, and that both men were well-loved by their congregations, characteristics that contributed to their effectiveness as leaders, both in the church as well as in the union hall. She also recognized this when she told Portelli that "people love "preachers.” And the preachers have a weight

${ }^{26}$ Debbie Spicer, interviewed by Alessandro Portelli, 10 October 1988. 
with the people, you know. Now, brother Gilbert over here, brother

Gilbert was pastor in that church when they blowed it, you know. And

this preacher you see was a good man, and they knowed that the sinner

people had a-fit for them preachers. Yeah, they would, cause they knowed

they lived good.[sic $]^{27}$

Just few days after Moses and his family moved to Kenvir, the Closplint Church was dynamited and completely destroyed. In his interview with the LaFollette Senate Committee, Reverend Moses told the committee that the church had not been used for anything but a church until the United Mine Workers began to meet in it. ${ }^{28}$ Mrs. Spicer no doubt concurred with Reverend Moses' testimony. In his interview with Mrs. Spicer in 1988, Portelli asked Mrs. Spicer “Who blowed it? Which side?” She replied, “Oh, they was [sic] having union meetings, so you can take it for granted which one did it." ${ }^{, 29}$

Soon after the building was destroyed, church members tore the church down. Eventually, men of the Closplint church and the Lynch Church of God purchased an abandoned theatre building, razed it, and used the lumber to rebuild the Lynch and Closplint churches. There was no doubt in Debbie Spicer's mind as to who was responsible for setting the dynamite at the Closplint church. Lynch Church of God burned during the same period. Extensive research in church records and conversations with the

\footnotetext{
${ }^{27}$ Debbie Spicer interview. A thorough search through Church of God Annual Assembly Minutes and Records failed to turn up any minister by the name of Gilbert, but the clerk of record during 1933- was a man by the name of Gilbert, who, in all likelihood, was taking care of the church's pastoral duties. In 1933, the Closplint Church of God (Cleveland, Tennessee) had been in existence for only three years. The congregation was very small and, in all likelihood, did not have its own pastor during its early years. Like many of the Church of God congregations in Kentucky during this time, the congregations were served by visiting clergymen and evangelists, while clerks of record managed the day-to-day needs of the church. When the union local began meeting at the Closplint church, its clerk may have been a miner by the name of Gilbert.

${ }^{28}$ Testimony of B.H. Moses, LFCH, Pt. 10, 3499.

${ }^{29}$ Debbie Spicer interview.
} 
present pastor of the Lynch church and a former church member who has written about the church's history reveal that the origin of the fire was not of a suspicious nature. ${ }^{30}$ The mining families of the Blackbottom Baptist Church and the Closplint Church of God and the union locals that met there may have lost one battle, but they were determined not to lose the war.

Once the 1933 contract with the HCCOA went into effect, the miners began holding their union meetings at the company theater in Louellen, where they continued to meet until the contract expired on April 1, 1934. The miners worked under an extension for thirty days, but the trouble continued for Preacher Musick before the extension expired. The anti-union violence intensified, particularly in the vicinity of HarlanWallins' Verda mine. In early May, when snipers fired on a Verda miners' rally at the Evarts ball park, the miners were forced to reconvene on railroad property at Ages. In the meantime, the Sheriff took aim at Marshall Musick. ${ }^{31}$

With the expiration of the contract's extension on Saturday, May 19, came a renewed assault against the union. Sheriff Middleton announced his strike strategy the day before when he announced that he intended to take "drastic action" to cleanse the county of "roving bands of troublemakers" who were using "mob violence" to coerce the coal operators into signing a union contract. ${ }^{32}$ The sheriff's announcement did not affect the union's plans to hold a Sunday afternoon rally at Verda. As soon as the strike began, deputies Ben Unthank, George Lee, Frank White, Charley Bleyer, and “another man” arrived to arrest Marshall Musick. At the time of his arrest, the deputies failed to inform the preacher of the charge. Knowing that it was safer to accompany them back to Harlan

\footnotetext{
${ }^{30}$ Reverend Marshall Rainey and Mrs. Bennie Wilder, telephone interviews with author 7 March 2006.

${ }^{31}$ Testimony of Marshall Musick, LFCH, Pt., 11, 3814.

${ }^{32}$ Hevener, Which Side Are You On? 109.
} 
than resist, Musick left with the deputies and was taken to the court of Judge Morris Saylor and charged with criminal syndicalism. Reverend Musick was jailed without bond and remained incarcerated for a little more than nine hours when he was finally released on a $\$ 5,000$ bond and ordered to appear for trial on the following Monday.

The operators took their anti-union campaign to the community on the following morning via the Harlan Enterprise. On Sunday morning, the editor of the Harlan Enterprise exhorted the county's citizens to support their sheriff, who was acting to protect their homes from "lawless bands” of union pickets, “idle men without jobs” who did not want jobs and "would not work if they had them.” Earlier that morning, a truckload of union miners from Liggett gained access to the Verda rally. Soon, sheriff's deputies arrived, ordered visiting miners to leave, and blockaded all highways to prevent other miners from attending the rally. ${ }^{33}$

When Musick went to court for his trial on the morning after the foiled rally, he found that the presiding judge was none other than the miner's candidate for county judge, Morris Saylor. Within minutes of convening the trial, the judge ordered Sheriff Middleton to call Bob Lawson, the superintendent of the Cornett-Lewis Mines, to see "what he wanted done about the case" and reset the case for later that day. Before the trial could reconvene, the judge and county attorney Elmon Middleton called Musick and his attorney into a consultation room and told them that Lawson was willing to dismiss his case, as well as cases lodged against other miners arrested on house detainer warrants, if they would return to camp. As the men mulled over the offer, William Turnblazer sent word that the contract had been signed and ordered the miners back to work.

\footnotetext{
${ }^{33}$ Hevener, Which Side Are You On? 108-109; Harlan Daily Enterprise 18, 20 May 1934.
} 
Turnblazer appointed Musick as a district field representative in June, putting him in charge of the Cloverfork section, an area that eventually included seventeen locals. On a Sunday afternoon in June, the union scheduled a rally at Shields. Musick was leading a group of Cornett-Lewis miners down the railroad tracks to the rally. As they approached a road crossing near High Splint, a group of armed deputies stopped them and turned them back. When Musick lagged behind the group, George Lee jabbed him with a rifle, temporarily paralyzing his leg and hip. When the preacher fell, Merle Middleton, the sheriff's cousin, kicked him across the railroad tracks. Other deputies pistol-whipped a miner until he bled profusely, and others were threatened and abused. ${ }^{34}$

Musick continued to work at Cornett-Lewis as a checkweighman until August 6 when the mine superintendent informed him of a new law that made it illegal to draw a salary for two positions. In addition, the superintendent told Musick that he could be prosecuted if he continued. Upon hearing this, the miner preacher resigned his position with the coal company and was soon served with an eviction notice. ${ }^{35}$

As Musick traveled throughout the section, Musick was constantly being shadowed by sheriff's deputies. He successfully eluded them by removing his dentures or wearing a heavy, jacket and a miner's cap and blackening his face with coal dust. Just as B.H. Moses, the preacher organizer often realized that he was in too much danger to return home to his family at the end of the day. When he requested protection from county officials, Sheriff Musick told him that as long as he continued to work "in the racketeering labor organization,” neither he nor his family could expect any assistance from the sheriff's department. The Musick family paid the ultimate price for the

\footnotetext{
${ }^{34}$ Hevener, Which Side Are You On? 109-110; Testimony of Marshall Musick, LFCH, Pt., 11, 3810-3811.

${ }^{35}$ Testimony of Marshall Musick, LFCH, Pt., 11, 3820.
} 
preacher's involvement in the union when their oldest son Bennett was murdered during the 1937 organizing campaign.

When the campaign began in early January of that year, the Musick family was living in the town of Evarts. With the beginning of the campaign came a renewed effort to intimidate and harass Marshall Musick, his wife Mallie, and their five children. One instance took place on the way to visit members of his congregation in the nearby town of Ridgeway. On the last Sunday of January, Reverend and Mrs. Musick left their home in Evarts to travel by foot to visit the Brewer and Adkins families. Mr. Brewer and Mr. Adkins were deacons at Reverend Musick’s church, and they were meeting to discuss the effect that the meningitis ban was having on their church. Citing supposed cases of meningitis, the director of the county health department had closed schools and churches while roadhouses and taverns owned by Sheriff Middleton and his friends remained open. Musick thought that if “Middleton's folks could sing and dance with a packed dance hall, 6 or 7 nights out of each week," then churches "should have a right to meet and sing and pray and preach.”36

As the Musicks walked along the highway, they spotted two cars occupied by a coal company official from the Cook-Sharpe Coal Company and several deputy sheriffs. Once the deputies saw the Musicks, they began to follow them. When the Musicks realized that they were being followed, they decided against visiting the Brewers. Mr. Brewer worked for the coal company, and a visit with the union organizer would probably result in his discharge. With this decision made, Mr. and Mrs. Musick made their way to the home of Mr. Adkins.

\footnotetext{
${ }^{36}$ Testimony of Marshall Musick, LFCH, Pt., 12, 4231.
} 
While the Musicks were visiting with the Adkins family, Mrs. Brewer and her son arrived. Mrs. Brewer told the Musicks that "there was some indication" that the minister was under surveillance and in danger. After a great deal of discussion, the couple decided to return home later that afternoon. This time, however, they decided to catch a bus, down the highway from the Brewer home. As they walked along the side of the road, the preacher organizer and his wife began hearing shots fired from two different angles. Fortunately, none of the shots hit their intended targets, and Marshall and Mallie continued walking until the bus pulled up along side them. When the bus stopped at the White Elephant saloon to pick up passengers, they saw the same two cars that had followed them earlier, parked by the side of the saloon. The Musicks arrived at their home, safely, but they knew that the danger was not over. ${ }^{37}$

On February 9, Reverend Musick went into Evarts, where he learned that fellow organizer Tom Ferguson had been shot the previous evening and was in serious condition. While he was in town, he saw George Middleton, the uncle of Sheriff Theodore Middleton who warned Musick that his life was in danger and that he should leave town. He also spoke with John Clem, the police judge in Evarts. Like Musick, Clem was a marked man, having decided against Merle Middleton, another one of the sheriff's relatives in several cases. Clem had received a similar warning and told his friend that they both would probably have to leave the county. As the preacher went about his business, he was closely followed by numerous sheriff deputies, acts that served to underscore the warnings that he had received.

When Musick returned home, he told his wife about the warnings and the news of Tom Ferguson's shootings. Realizing that his family was in danger, Reverend Musick

\footnotetext{
37 Testimony of Marshall Musick, LFCH, Pt., 12, 4230-4231.
} 
and his wife decided that they would be safer if he left for a while. The preacher organizer remained at home, with his family until later that evening. He had decided to take the 7:00 coal train to Pineville, hoping that his departure would be hidden under the cover of darkness. Just before Musick started for the train station, he called to his son Bennett and told him of the warnings that he had received earlier in the day. As he started to leave the house, he said, "Bennett, I want you to stay here tonight and try to take care and watch over your mother and the other children.” The young man agreed, saying, "Pop, I will do that.” These words were the last ones that he would ever hear his son speak. Before he reached Pineville, Bennett Musick was dead.

After returning home from walking her husband to the train, Mallie and her four children, Pauline, their oldest child and only daughter, Bennett, who was nineteen years old at the time of his death, and his younger brothers, Virgil and Bert, gathered together in the living room. The preacher had been gone for only an hour and a half when the first shot rang out, entered the living room near the fireplace. Upon hearing the second shot, Mallie, Pauline, and the two, younger boys rose from their seats and headed for the bedroom and dropped to the floor. Bennett was already there. A week after the shooting, one of his brothers recalled seeing Bennett get out of his chair and head for the bedroom after the first shot was fired. The shot hit the nineteen year old, for he fell to the floor shortly after he turned into the bedroom. The family remained on the floor for several minutes after the gunfire ceased. When it was over, they found Bennett, already dead. ${ }^{38}$

With the murder of Bennett Musick, the operators and their hired guns in the sheriff's department had overstepped the bounds of common decency. Over the years,

\footnotetext{
38 Testimonies of Marshall Musick and Mallie Musick, LFCH, Pt. 12, 4229-4239; John Hevener, Which Side Are You On? 135.
} 
the people of Harlan had become de-sensitized to the harassment, beatings, and wounding of union organizers, but the cold-blooded murder of an innocent, young man was more than they could stomach. Deputy Sheriff Henry Lewis, no doubt suspecting that his fellow officers were involved, resigned his commission, admitting that "killing the Musick boy... was a bad piece of work.” Leaders in the community, however, managed to keep “a lid on it locally.” Both a regular and a special grand jury, one headed by a deputy and the other headed by an operator's brother, investigated the Ferguson wounding, and the Musick murder, and other incidents of violence against union officials, and adjourned without returning indictments. ${ }^{39}$

Local officials and operators were able to keep “a lid on it,” but they were powerless to do the same once the news reached the rest of the nation. The murder provoked the La Follette Committee's investigation, an investigation that proved to be "the turning point in the ongoing struggle to free the miners of Harlan County." Union officials temporarily suspended their campaign and traveled to Washington, D.C., with affidavits and photographs to urge the committee to investigate the terrorist campaign against the union. The committee staff quickly began issuing subpoenas, and on March 22, held a preliminary session. On April 14, two days after the Supreme Court upheld the Wagner Act, the committee convened regular sessions. ${ }^{40}$

A week after the committee convened, William Turnblazer asked George Titler to come to Jellico. The district president told the organizer that the "ordeal in Harlan had made a nervous wreck" of lead organizer "Tick" Arnett and handed the reins over to Titler. Turnblazer gave Titler a check for $\$ 3,000$ and told him to establish a payroll and a

\footnotetext{
${ }^{39}$ Hevener, Which Side Are You On? 136.

${ }^{40}$ Hevener, Which Side Are You On? 135-137.
} 
headquarters in Harlan County. With his appointment and this initial check, the international began to pour money into the county. Titler established his headquarters in the Turner Building in Evarts and hired Bob Hodge, Matt Hollars, and Bob Owens, from Morley, Tennessee, Virgil Hampton, Ed Beane, and Jim Westmoreland. Hampton and Beane were from Black Mountain, and Westmoreland was now living in nearby Big Stone Gap, Virginia. Reverend Matt Hollars remained on with Titler, rounding out the international representative's inner circle of lead organizers. ${ }^{41}$

Neither the press nor the recent commencement of the LaFollette Senate Committee hearings lessened the harassment and intimidation of organizers and unionists. Organizers had to remain on guard, constantly, if they hoped to remain among the living. Another obstacle to the organizing drive was the constant accusation of antiunion forces that the organizers were "red-necked Communists, atheists, and anything else that was distasteful to the Mountaineers' code." ${ }^{42}$ The local unionists had an important weapon in their arsenal to combat such accusations: four preachers; Musick and Clontz were from Harlan County, Hollars was from nearby Jellico, Tennessee, and Bunch was from Illinois. They were featured union speakers during the 1937 campaign, and advertising circulars for mass meetings always announced the speakers as Reverend Matt Bunch, or Reverend Matt Hollars, or Reverend Marshall Musick, or Reverend William Clontz. In one meeting at Lynch, the union advertised all four as speakers, a strategy that was very effective against U.S. Steel \& Coke’s propaganda that union organizers were "evil men." One of the circulars read as follows:

\footnotetext{
${ }^{41}$ Titler, Hell in Harlan, 137.

${ }^{42}$ Titler, Hell in Harlan, 140.
} 
TO THE MINERS OF BENHAM AND LYNCH ORGANIZATION CAMPAIGN UNDER NEW MANAGEMENT.

"By orders of the International Officers of the United Mine Workers of America, the organization of Benham and Lynch has been turned over to International Representatives Matt Bunch and George J. Titler, who have been in charge of organizing the commercial mines of Harlan County, under the jurisdiction of District No. 19. An entire change in policy will be inaugurated and the policies of the International and District Organizations will be carried out to the letter."

"Local unions at both Benham and Lynch will start holding secret meetings and a new tabulation of our membership will be taken. If you are in favor of a bona fide Labor Union, join the UMA of A."

"The personnel of the new organizing staff will be: Rev. R. A. Music, Rev. Wm. Clontz, Rev. Matt Bunch, and others who are wellknown and highly respected by the people of the community."

"If you have not joined this great organization, get in touch with Matt Bunch and his bunch of organizers who will explain the principles and benefits of the world's largest and greatest labor organization."

"The only bona fide collective bargaining agency for the coal miners of America."

"Get on the band wagon of the union that has brought 7 hour day, 35 hour week, time and a-half for overtime and 200 percent increase in wages to 97 percent of the coal miners in America in the last 4 years."

WILLIAM TURNBLAZER, President of District No. 19 GEORGE J. TITLER, International Representative in charge of Organization in Harlan County. ${ }^{43}$

\section{Reverend William Clontz}

Reverend Clontz had lived and worked in Harlan County since 1920, and at the time of his testimony before the La Follette Senate Committee, he was a lay minister in the Methodist Church at Wallins Creek. Until the union hired him as a field representative in 1934, he worked at the Creech Coal Company, where he had spent the last nine years as an assistant foreman. Reverend Clontz first joined the union after the

\footnotetext{
${ }^{43}$ Titler, Hell in Harlan, 140-141.
} 
passage of the NRA and participated in contract negotiations in 1934. As a field representative, he was in charge of the southern end of Harlan County as well as four locals. Reverend Clontz became known as an "emotional union stalwart," and he was consistently hounded by sheriff deputies. In time, however, the harassment escalated beyond surveillance, intimidation, and threats, to acts of violence against the man and his family. $^{44}$

Of the four companies whose miners were under UMWA jurisdiction and in Clontz' charge, the Creech Coal Company gave the union and this field representative the most trouble. Reverend Clontz told the committee that he "probably had him (R.W. Creech) before the board every month during the life of this arbitration board” and only succeeded in reaching a settlement with the mine operator "two or three times." While relations between Clontz and R.W. Creech were always “civil,” this was not the case between the preacher and Creech's son Ted. In one particular instance, in an apparent attempt to intimidate the minister, Ted Creech showed Clontz his .45. When Senator La Follette asked Clontz about the occasion that surrounded the incident, the preacher told him that he "never took the time to ask... and ran away to keep from getting killed."45 Hostilities between the union and the coal operators continued to mount during 1934, and Reverend Clontz realized that he, too, was a marked man. In one incident, the preacher found three sticks of dynamite, two caps, with forty feet of fuse hooked to it, placed under his son's bedroom. The fuse had been lit and burned up to about ten feet of the cap when it burned out. The preacher learned of the attempt on his life when his dog found it, dragged it out from underneath the house, and laid it on the front steps. Clontz

\footnotetext{
44 Taylor, Bloody Harlan, 71.

45 Testimony of William Clontz, LFCH, Pt.10, 3623-3627.
} 
reported the incident to Harlan County circuit court judge James Gilbert, but no attempt was ever taken to investigate the matter. The preacher organizer also received a threatening letter through the mail. Marked as Exhibit 1237 in the LFCH appendices, the letter read as follows:

BILL CLONTZ: A word of Worning [sic] if you don't quit giving Trouble you will be took out of her and you want return any moore don’t let this slip you mind.[sic] ${ }^{46}$

On the third Monday of September 1934, gunmen shot up his home while he was in Knoxville, at an arbitration meeting. His elderly mother, the preacher's wife, and his son were home at the time. As was frequently the case, he and Mr. Creech were in front of the board over a grievance. Since the hour was late when the meeting adjourned and he had other cases to present, Clontz decided to remain in Knoxville for the night. Since the two men had shared a cordial relationship, he asked the operator to stop at his home and tell his wife that he would most likely be returning home before the following evening. Mr. Creech agreed and arrived at the Clontz home about 9:30. Everything was quiet at the Clontz home until approximately four hours later when ten shots were fired through the house. When the hail of gunfire stopped, his wife found four bullets in their son's bedroom, in the front of the house, near the highway. One bullet had passed just above their sleeping son's body, while a second bullet passed below his body, traveling through his pillow, missing his head by an inch or an inch and a half. The .45 bullet split the boy's mattress wide open. The bullets had come through the front window. In addition to the ones that landed in the boy's bedroom, some traveled into the dining room, where they smashed dishes, destroyed furniture, and various articles of clothing.

\footnotetext{
${ }^{46}$ Testimony of William Clontz, LFCH, Pt.10 3623-3628.
} 
The preacher was unaware of the shooting until he arrived in Wallins on the following evening. As he drove into town, several men ran up to his car and told him about the shooting. When he arrived at his home, a large crowd of people were there and his wife and son were in tears. That his only child came so close to "being destroyed while he lay sleeping, "rattled” the preacher's nerves. Clontz called a taxi and went to pay Sheriff Middleton a visit. When he asked the sheriff to send deputies to his home to investigate, the Sheriff told Clontz that he did not have a deputy in the area and had no intention of sending anyone to his home to investigate. Further arguments concerning his rights as a citizen and taxpayer who had "never been indicted for anything" failed to move the sheriff. The high sheriff had only one piece of advice for Clontz: "leave the county., ${ }^{47}$

The following morning, Reverend Clontz traveled to Harlan to take up the matter with the circuit court judge. When the sheriff saw him entering the court house, he motioned for Clontz and told him that he would send some of his men to the town of Wallins to investigate the shooting. His deputies arrived at the Clontz home before the preacher could return. Upon his arrival home, Mrs. Clontz told her husband of their visit, describing their questions and collection of evidence. Neither the sheriff nor the circuit court judge took any further action, and the matter was dropped. When Reverend Clontz asked Judge Gilbert about the shooting and the possibility of obtaining some protection for his family, the judge replied, "Mr. Clontz, you are just like I am; my hands are tied, and yours is, too. I cannot get my court waited on."

\footnotetext{
${ }^{47}$ Testimony of William Clontz, LFCH, Pt.10, 3631.

${ }^{48}$ Testimony of William Clontz, LFCH, Pt., 10, 3632.
} 
Shortly after the shootings, Ted Creech told Clontz that he was no longer permitted on Creech company property, and the company began discharging local officials, one at a time. In time, the Creech miners, fearing that they, too, would lose their jobs, stopped participating in union activities, and the union finally folded in $1935 .{ }^{49}$ Reverend Matt Bunch

George Titler remembered the Presbyterian minister and international representative from Illinois as the only preacher on his staff who carried a gun and Bible and was always trying to save his soul.

John L. Lewis first appointed Matt Bunch an international organizer in the spring of 1936, but reassigned the preacher organizer to District 30 shortly before Christmas. Bunch and his wife Laura left a lasting impression on George Titler. He said that the ordained minister "came from a different bread [sic] of cats." Matt was long, tall and lean, and smooth as a school marm's elbow. He married Laura Smiddy when they were both kids and had a large, fine family. They were inseparable.” Bunch and his wife Laura moved their family to Evarts shortly before the 1937 campaign began, into an apartment in the Turner building. Laura proved to be as courageous as her husband. According to Titler, "when a wave of terror broke out and it became necessary to stand guard at night, Mrs. Bunch stood guard with a shotgun” while her husband slept. ${ }^{50}$

Titler remembered the minister as a busy man who was always spreading the word of the Gospel or the union. When he was not making organizing speeches, he was in a pulpit preaching the Gospel, or "doing missionary work attempt to convert some heathen like me.” One evening, Titler and Bunch drove down to Wallins Creek to rescue

\footnotetext{
${ }^{49}$ Testimony of William Clontz, LFCH, Pt., 10, 3633.

${ }^{50}$ Titler, Hell in Harlan, 141.
} 
an organizer who was "trapped by some thugs." As they speeded down the highway, Reverend Bunch took the opportunity to lecture his superior on his sadly neglected spiritual life. Titler conceded to the truth of his words, but his was advice had little appeal in the heat of the moment. He once asked the preacher what he planned to do if they ever got into a fight and he was "forced to kill a thug in self defense? You go around with a Bible in one pocket and a pistol in another. If you are forced to kill a thug, you will probably sit down on a stump and search your Bible for a way to justify your deed. If that happens, Matt, and I was you, Matt, I would search in the Old Testament. You might find something comforting under Mosaic law.”51

Matt Bunch firmly believed that the organization of Harlan County was under “divine guidance.” The preacher never "converted” Titler, but he made a believer out of the old union man on this point. The union held mass meetings every Sunday for eighteen months, and not one meeting was ever rained out. ${ }^{52}$

\section{Matt Hollars}

Matthew Hollars was a Holiness preacher, most likely at the Jellico (Tennessee) Church of God. ${ }^{53}$ Only men of great courage were considered for employment as organizers. This became especially true in 1937 after the operators' stepped up their antiunion campaign, and George Titler and his organizers put the operators' association on notice that they were now armed, and, if necessary, were ready to defend themselves against the association's legion of hired guns. Nevertheless, one man still refused to

\footnotetext{
${ }^{51}$ Titler, Hell in Harlan, 141-142.

52 Titler, Hell in Harlan, 140-143.

${ }^{53}$ This author could not find Hollars on any of the lists of licensed or ordained ministers from Church of God (Cleveland) records. However, an article in the UMWA describes a rally that the UMWA held in Harlan County in 1939 in observance of the Eight Hour Day. Approximately four to five thousand persons attended the anniversary celebration and enjoyed music supplied by the Cloversplint quartet, string bands and quartettes from Lynch, Verda, and a singing program from the Jellico Church of God choir, sponsored by G.M. Hollars. “At Harlan, Ky.,” United Mine Workers Journal, 4 April 1939, 15.
} 
carry a gun: Matt Hollars. According to Titler, this Holiness preacher had "plenty of courage,” but he depended upon practicing passive resistance and by preaching the Word of God wherever he went. And it worked. The preacher was "absolutely fearless" and traveled throughout the county, unmolested. Matt Hollars' preaching appealed to Titler, because, like Marshall Musick, he "preached short sermons." ${ }^{54}$

\section{Hamp C. Wooten}

Hamp Wooten was not a preacher, but he was a leader in the Lynch Church of God. It was not unusual for boys as young as nine or ten years of age to go to work in the mines during the early years of the coal industry. More often than not, they went to work with their fathers, working first as trappers or breaker boys, before moving on as miner's helpers, and finally, full-fledged miners. For these boys, childhood soon became a dim memory as they assumed the work and responsibilities of manhood. For Hamp Wooten, the experience turned him into a diehard union man.

The Wooten family was of Cherokee Indian lineage and left the reservation in North Carolina and settled in Leslie, Clay, and Perry counties. Eventually, members of the Wooten clan made their way across the mountains, into Harlan County, to work in the mines. ${ }^{55}$ Hamp Wooten was born in Clay County in 1905 and would follow the men of his family into the mines as well. At the age of eleven, Hamp left school to go to work in the mines. The experience taught him a valuable lesson: without a union, miners would never see good wages and benefits or an end to child labor.

According to Reverend Alfred Carrier, a Pentecostal historian from eastern Kentucky who visited preachers around the region, Holiness meetings began to take place in the early to mid-teens and rapidly spread in the coal mining areas. Between 1910 and

\footnotetext{
${ }^{54}$ Titler, Hell in Harlan, 141-146.

55 "Wooten Family Heritage,” < http://www.pawsofpa.com/wooten_family_heritage.html> (4 May 2006).
} 
1912, Holiness believers began holding meetings in schoolhouses in Harlan County, and Holiness preachers preached on the streets and held meetings in homes. People traveled from the "far side of Pine Mountain" to attend a meeting on Wallins Creek in 1912, and the Creech Coal Company let participants ride mining machinery up and down the mountain to make the journey easier. ${ }^{56}$

By 1920, the holiness-Pentecostal movement had taken root in the county, and Johnson and Wooten families became leaders in the Church of God (Cleveland) in the city of Lynch. Initially, many holiness families from the Lynch area joined the Church of God in Harlan. Eventually, a small circle of believers started holding church services and prayer meetings in the home of John and Ethel Harris. As the circle expanded, the members began to take turns holding services at their homes. The thin walls of the miners' company houses could not soften the loud, emotional singing, praying, and preaching that was characteristic of Holiness-Pentecostal churches.

As the church grew, so did the complaints from the neighbors to the Lynch police department, occurrences that did not please the officials of U.S. Coal \& Coke. Thus, the congregation was forced to look for a possible site for their church outside the city limits of Lynch. When the former Moose Hall became available, three men of the congregation, William Powell, John Harris, and Blaine Adams, bought the building for $\$ 300.00$ to serve as the first home of the Lynch Church of God. The church was organized in 1930 with eight charter members. Of the eight, six were women, and three

\footnotetext{
${ }^{56}$ Callahan, “Working With Religion,” 175.
} 
of these women were from the Johnson-Wooten clans. Hamp’s future wife Mary was still a teenager when she and her two future sisters-in-law signed the church’s charter. Mary Johnson Wooten came from Irvine, Kentucky, where her father was a preacher and policeman before coming to Harlan County. After Hamp and Mary married in 1932, Mary taught school, and Hamp continued to work at U.S. Coal and Coke as a motorman. The two, young people were very religious people and determined that God would be the central, driving force in their family.

Both Hamp and Mary were devoted to God and their family, but their faith did not spare them from experiencing great sorrow when their first three infants, all boys, died in infancy. Their next three babies were girls, Beuna, Arizona, and Naomi, who thrived. Finally, Hamp, Jr., was born. Hamp, Sr., wanted his children to serve and "work for God." ${ }^{57}$ For this to happen, Hamp and Mary believed that, when the doors of the church were open, their family should be present. Thus, neither the lateness of the hour nor an early shift in the mines kept the family away from church. The Wooten children remember many mornings when, after getting home from a revival meeting that lasted until one or two in the morning, their dad still got up at 4.a.m., to get ready for work. ${ }^{58}$ Whether serving the church or the union, Hamp Wooten served God and man with fervor. For Lynch miners, it took more than fervor to belong to the union. It took courage and the protective hand of God almighty and men who were totally committed to furthering the gospel of Christ and unionism. Hamp was one of these men.

U.S. Steel miners such as Hamp Wooten, Otis King, and Adie Dossett worked under the cover of darkness to recruit enough men "to ask for something” between 1935

\footnotetext{
57 "Wooten Family Heritage."

58 "Wooten Family Heritage."
} 
and 1937. With John L. Lewis' refusal to contribute financial or organizational resources of any substance to the campaign and the federal government's inability to enforce the provisions of the Coal Code in Harlan, the miners certainly had their work cut out for them. Thus, if the union were to ever succeed in establishing a permanent beachhead in Harlan County, it would have to bring the miners of Lynch into the fold, once and for all. This would also require some definite changes in strategy, especially with the large number of black miners employed in U.S. Steel Corporations operations in Lynch.

U.S. Steel's Lynch mines employed thirty-two hundred miners, and union officials considered their conversion the key to successful organization. On June 3, 1933, in line with the company's national labor policy, the company instituted the Union of Lynch Employees (ULE), which the pro-operator Harlan Daily Enterprise praised as a suitable substitute for the United Mine Workers Union, an organization that the paper's editor "charged with harboring radicals and Communists."59 The company could depend upon the assistance of black preachers and leaders of black, fraternal organizations to exhort the virtues of the ULE over that of the United Mine Workers, a tactic that convinced William Turnblazer of the futility of holding an election at Lynch in November $1933 .{ }^{60}$ The steel giant resorted to more sinister methods to convince its miners that membership in the ULE was in their best interests, namely violence and intimidation. Harassment and threats of violence and dismissal were especially effective with its substantial number of black miners until 1937.

By January 1, 1934, mine owners had regained political control of the county, and thereafter, until 1937, privately paid deputy sheriffs harassed both union organizers and

\footnotetext{
${ }^{59}$ Hevener, Which Side Are You On? 104; quotation from the Harlan DailyEnterprise, 5 June 1933.

${ }^{60}$ William Turnblazer to Philip Murray, 24 November 1933. Penn State University, Special Collections \& Labor Archives, UMWA MSS, Box 89, fl 3.
} 
miners alike. In 1934, the majority of the county’s black coal miners were employed by U.S. Steel. In fact, more than half (55 percent) of its work force was black. ${ }^{61}$ The company launched a campaign of violence and intimidation against their black miners that effectively discouraged them from joining the UMWA. When the Harlan agreement was up for renewal in the spring, operators intensified its campaign, prompting UMWA Local No. 6067 (the Lynch local in Cumberland) to file a resolution against U.S. Steel with the national labor board. In it, the union specifically charged the company with violating the right miners had under Section 7 (a) to join the union of their choice without discrimination, violence, or intimidation. According to the resolution, which was published in the April $15^{\text {th }}$ edition of the United Mine Workers Journal, U.S. Steel had "hired sentinels” posted at or around their homes to keep them from attending regular meetings of the union. Besides the posting of guards in the black sections of Lynch, deputy sheriffs and mine guards interfered with conversations between miners and union officials, sometimes by stepping on their toes or handcuffing miners and threatening them with the loss of their jobs if they repeated the offense. The harassment extended to meetings other than those of the United Mine Workers as well. In one instance, a meeting of the Knights of Pythias was being held in their hall in Lynch. Mine guards had been posted around the building and overheard the membership discussing the United Mine Workers. Upon hearing this, the guards entered the hall, removed the speaker, ordered him to leave the town, and never return. The most damning threat was one that surely rattled black miners to the core. It involved the loss of their livelihoods. Company official told miners that joining the UMWA would result in the loss of their seniority

\footnotetext{
61 “Colored Miners at U.S. Steel Mines Demand Right to Join U.M.W.A.,” United Mine Workers Journal, 15 April 1934.
} 
rights and be taken off motors and machines (two of the better paying job classifications in the mine), and ultimately be replaced with white miners. In one instance, a paid company committeeman told miners assembled in the bath house that if any of them joined the union, they would be fired. James Moreland and Joe Norris, the president and secretary of Local No. 6067 filed an unfair labor resolution against the company, hoping to assure the company's black miners that charges made by company officials were false and that the union was totally committed to the ideals established in the union's constitution. $^{62}$

The experience of one black miner at Lynch had already proved that the company's threat to dismiss miners who joined the union was not an idle one. His story made its way to Reverend Carl Vogel, the minister at the Cornett-Lewis Methodist Memorial Church, one of the few company preachers willing to stand up against the nonChristian behavior of the operators in his congregation. The miner, who was rumored to have signed a UMWA membership card, entered his assigned room in the mine, only to be told by his boss that he would not be the only miner working the room during that shift. The supervisor told him that seven or eight other men would be working the room as well. Since he was paid by the ton, having to share his room with other miners would restrict his ability to make any money at all that day since each man would have to take a turn at working in such a small space. In the end, the black miner had no other option but to leave.

\footnotetext{
62 “Colored Miners,” United Mine Workers Journal.
} 
His boss ordered him out of the mine in order to make space for the white miners waiting to replace him in his room. ${ }^{63}$

The harassment extended to miners' families off company property as well when a large group of mining families from Lynch traveled to Cumberland to attend a carnival during the fall of 1935. When they arrived, they were met by a gunman who threatened the miners with dismissal if they did not return to Lynch. The carnival provided local unionists and organizers with an ideal opportunity to approach Lynch miners about joining the union. Thus it is no wonder that the company clearly did not want its miners in Cumberland, especially its black miners. ${ }^{64}$ According to Philip Murray, the only obstacle to establishing a union for the U.S. Steel miners within the fiefdom of Lynch was the resistance of its black miners. The majority would have most likely abandoned the company union for the United Mine Workers. It would be foolish to ignore the race factor in southern culture. Yet, as this dissertation has already shown, racism was no longer an impediment to working class conscious. The mighty fist of the steel giant kept its black miners in their place.

George Titler came to Harlan County in 1937. In January, District 19 President William Turnblazer presided over a convention whose sole purpose was to plan and organize a new campaign to organize the Harlan miners. At the time, Titler was working in Chattanooga, Tennessee as a field representative for the UMWA in charge of the mine workers in the Sequachia Valley and Tracy City area. Upon hearing of the up-and-

\footnotetext{
${ }^{63}$ This miner was not a member of Reverend Vogel's church. Evidently, the minister had heard the story and related it to William Hutchinson during a conversation. Memorandum regarding an incident July 1934, as told to William J. Hutchinson, the president of Berea College, by Mr. Carl Vogel. Berea College, Hutchinson Library, Southern Appalachian Collection, Harlan County Struggles MSS, Box 1, fl 8.

64 "Brutal Gunmen Terrorize Colored Miners of Harlan County, Kentucky,” United Mine Workers Journal, 1 September 1935.
} 
coming convention and campaign, he asked Turnblazer to assign him to Harlan County. Upon hearing Titler's request, the district president told him that he was "nuts," because "the men who go into Harlan County will probably come out feet first." In spite of his initial reservation, Turnblazer assigned Titler to the Harlan field.

According to Titler, the convention was an "enthusiastic one," with the International pledging its support through various speakers that included several District officials. Representatives came District 5 (Pittsburgh), 17 and 31 (West Virginia), 20 (Alabama), 23 (Western Kentucky), 30 (Eastern Kentucky), and District 28 in Virginia. Each of the Districts loaned one or more of its organizers for the drive which was to be headed by District 19 Vice President “Tick” Arnett. Besides Titler, District 19 organizers Reverend Bill Clontz and Reverend Marshall Musick were to assist Arnett in the next campaign. Reverend Matt Bunch, an international representative from District 23 would also lend a hand. ${ }^{65}$

In April, the union held a rally at Evarts where union organizers explained the Wagner Act and its benefits to organized labor to a crowd of miners and their families. International organizer Matt Bunch told the crowd that the union the miners now "have the arm of the United States Government around our necks," and urged miners to join the union to realize their dream of better wages and working conditions. International representative George Titler told them the crowd that the Supreme Court's upholding of Wagner finally "made Harlan County safe for democracy" and that the opening of the organizing campaign was "not a joke," that it was the "law and the fact." As the speakers praised Wagner and the benefits of union representation, organizers moved throughout

\footnotetext{
${ }^{65}$ George J. Titler, Hell in Harlan (Charleston: BJW Printers, 1972), 135.
} 
the crowd, seeking new members. Union representatives told the miners that the union had already signed up a thousand miners and hoped to sign up all 16,000 of the county's miners within the next sixty days. ${ }^{66}$

The union may have had the "strong arm of the U.S. government around its necks” in April of 1937, but this did not stop operators from resorting to strategies that had served them well in the past. Operators stepped up their anti-union campaign by threatening miners with dismissals and evictions, intimidation, harassment, and violence. This was especially true at Lynch. One of U.S. Steel \& Coke's tools in its arsenal in the fight against the UMWA was a man known as "Preacher Johnson." Johnson worked for U.S. Coal \& Coke as both a "classified worker" and as a boss. Before his employment with the coal company, Preacher Johnson had served as a deputy to both John H. Blair and Theodore Middleton. Titler described Johnson as a "big... ugly... so-called preacher” who beat up men at Lynch who no doubt answered to the head of the company's police force. For the first three and a half months of the campaign, union organizers were not permitted to carry arms of any kind even though it was not against the law to carry a gun in the state as long as it was not concealed. This would change as companies such as U.S. Coal \& Coke stepped up their anti-union campaign. It was decided that every man was allowed to carry a pistol in accordance with the law so that he could "face as an equal the convicts parading as minions of the law." They were instructed that, if the gun thugs tried to stop them as they lawfully carried out their duties, they could meet "force with force," but that they should use their guns "only in selfdefense.” The organizers informed George Ward, secretary of the operators' association

66 “Many Sign Up In Union’s Harlan Drive,” Knoxville News-Sentinel, 26 April 1937. 
and warned him that they were now armed and intended to defend themselves when necessary. However, fearing a veto, no one asked the district president for his approval. Having to carry arms while traveling around the county had become a necessary evil, but the federal government was about to "clip the wings" of operators such as Pearl Bassham through the actions of the LaFollette Senate Committee. ${ }^{67}$ The hearings dealt with the period 1933-1937 for two reasons. Focusing on years when the miners' right to organize and bargain collectively had been protected by federal law strengthened the position of the government and avoided the "embarrassing" union violence of 1931. The committee sought to prove that the HCCOA was continuing to finance and direct a conspiracy to control county politics and to use the sheriff's department to prevent unionization of the county's miners in direct violation of federal law.

The committee exhibited an association by-law that pledged its members to oppose the closed shop as a way to indicate that one of the group's main purposes was to wage war again the organization of its miners. Witness testimony and association minutes proved that during each of the union's major campaigns in 1933, 1935, and 1937, the organization had doubled its assessments on member coal companies. In addition, the committee exposed the direct link between the association and key county political officials.

The La Follette Committee was more interested in discrediting antiunion employers and assisting the CIO unions in organizing industrialists' shops and mines than gathering information that would produce subsequent labor legislation or deal with violators of the Wagner Act. ${ }^{68}$ Although the committee’s work did not force local

\footnotetext{
${ }^{67}$ Titler, Hell in Harlan, 142-148.

${ }^{68}$ Hevener, Which Side Are You On? 141.
} 
operators to accept a union contract, it did result in a temporary local upheaval in local politics, the permanent abolition of the private mine guard system, and the nearly solid organization of local mines almost while the committee was still in session. These changes allowed the union to reenter the county on April 24, 1937, and to make its first real gains in four years, as, every Sunday, between April 25 and June 20, the union held giant rallies protected by the state police. By August, nine thousand, or 65 percent, of the miners had taken the obligation. Only this time, miners openly took the oath, without the cover of darkness. On April 2, 1937, the union finalized a two-year national agreement that provided for a $\$ 5.60$ southern basic daily wage and a seven hour day. However, because Black Mountain was the only county firm to sign the agreement, the rest of the operators held out for a month. Two, important events no doubt persuaded the Southern Appalachian operators to relinquish their opposition. First, the Steel Workers' Organizing Committee and U.S. Steel Corporation reached an agreement on March 2 that certainly fueled the hopes of U.S. Coal \& Coke’s three thousand miners at Lynch that they, too, would be under a UMWA contract. Because of this, Tennessee and southeastern Kentucky signed a union contract on May 2. In mid-May, Governor Chandler began pressing the county's operators to negotiate a contract for its miners.

With the signing of a contract with the Steel Workers Organizing Committee in 1937, covering the plants of United States Steel Corporation, its mining subsidiaries were under intense pressure from the parent corporation to "fall in line.” The H.C. Frick Coke Company, a subsidiary of the mighty steel corporation, signed a contract with the UMWA in April 1937. The United States Coal \& Coke Company in Lynch also signed a contract covering the union's membership in the UMWA later that summer. As a result 
of the La Follette committee’s investigation, several mines, among them, Harlan-Wallins and Clover Splint, withdrew from the HCCOA. The union made significant gains following June 21 as the union signed contracts at Harlan-Wallins, Clover Splint, Harlan Crown, Black Mountain, U.S. Coal \& Coke, Black Star, and Berger and Cook \& Sharpe, contracts that covered nearly five thousand miners. By the end of the year, approximately six thousand of the county's miners were covered by some type of UMWA agreement.

Although the HCCO only represented the interests of the employers of six thousand miners in the county, the operators stood firm, giving the union "the strongest opposition" that it had ever faced in the county. In spite of the union's blanket invasion of talented organizers and the stigmatism of being dressed down in public through the activities of the La Follette Commission and subsequent FBI investigations, association members once again began discharging union employees and initiated a new strategycompany unions-to thwart organization. Because the operators refused to sign a contract, the federal government moved against them. On September 27, the federal grand jury in Frankfort indicted twenty-two coal companies, twenty-four coal operators, Sheriff Middleton, and twenty-two of his deputies for conspiring to deprive miners of civil rights accorded them under the Wagner Act. The defendants were charged with violating the Civil Rights Act of 1870, Section 19, Title 18, of the U.S. Criminal Code, which provided for a maximum penalty of ten years' imprisonment and a $\$ 5,000$ fine. In 1938, after spending $\$ 1$ million to defend themselves in a conspiracy case (U.S. vs. Mary Helen) which they subsequently lost, the operators' association finally agreed to sign a union agreement rather than submit to retrial of the case. After obtaining John L. Lewis' 
approval, Turnblazer, Titler, and the association signed a contract in Cincinnati, on August 28. By the close of 1938, more than twelve thousand miners were under UMWA contract. In September, George Titler told the U.S. attorney general’s office that “every Operator in Harlan County is doing their utmost to keep the faith and it is my opinion this matter is working out as well as can be expected.” 69

When the union began its 1937 campaign, the organizers from District 19 knew that they would have to use every ounce of strength available to fight back against U.S. Coal \& Coke and to organize men of nearly every creed and color. One of union’s greatest strengths was the rank and file members who worked during the drive. Two men stood out in George Titler's memory: one was a black moderator of the Baptist church whom he hired to help organize his congregation. Under Titler, the union increased its hiring of local, black miners as organizers. The other man was Hamp Wooten. Wooten was a motorman at the company's Lynch mine in 1937. He may have been small in stature, but he had the "strength and courage of a wolverine.” In 1937, the union established its first local in the city of Lynch. Local 7425 held its first meeting to a standing room only crowd of more than five hundred miners in the basement of a local church, with Hamp Wooten as its president. Hamp engineered the building of the Lynch local union hall that was dedicated January $1,1940 .^{70}$ What many had believed to be impossible was now a reality.

\footnotetext{
${ }^{69}$ Hevener, Which Side Are You On? 143-147; 151, 153.

${ }^{70}$ Titler, Hell in Harlan, 145; Wagner and Obermiller, African American Migrants and Miners, 75.
} 


\section{CONCLUSION}

So the ark of the Lord compassed the city, going about it once:

And they came into the camp, and lodged in the camp.

Joshua 6:11

The power of the Harlan County Coal Operators Association had finally been broken. What its officers had declared to be impossible was realized. With the help of the United States government, the people had finally been heard. Thus, it was with a great shout (through the testimony of witnesses to members of the Senate LaFollette Committee), the back of the Harlan County Operators Association had been broken, and a local union of the United Mine Workers was established in Lynch in 1937. The late Judge Elbert Gary, the former president of U.S. Steel, surely turned over in his grave when the corporation signed an agreement with the United Mine Workers the following year. A local of the UMWA was now lodged in the coal camp of Lynch, one of the jewels in the company’s crown.

By 1940, scholars had already begun to scrutinize the region's culture of otherness and poverty. Questions began to surface that, up until now, remained unanswered. Sociologist John Holt was the first scholar to wonder if a connection existed between the popularity of holiness-Pentecostal sects and the growth of labor unions. In his article, “Cultural Shock and Social Reorganization,” Holt posed a question for future research when he said that it would be "interesting to see if there is a correlation between "the phenomenal growth" of the Holiness and Pentecostal denominations or sects in rural-industrial areas where former agricultural workers migrated to find work in coal mines and textile mills and the rise of labor movement in 
these rural-industrial areas. ${ }^{1}$ More than forty years later, the question resurfaced during interviews that Alessandro Portelli was conducting with miners and their families on life and work in Harlan during the 1930s. His interviewees had little to say about the role of international leadership of the UMWA, leading the renowned scholar to ask several miners and their wives, "Who really organized Harlan County?" The response was always, "the miner preachers."

Theology student and activist Michael Szpack realized that a link might exist between the Church of God (Cleveland, Tennessee), the rise of the mining and textile industries, and the growth of trade unions in Southern Appalachia as he conducted research for a series of papers during the 1980s and 1990s. By 2000, Szpack was an ordained minister in the Methodist Church and a religious liaison for the AFL-CIO. As this scholar and Szpack discussed their work in a series of telephone conversations and visits, the question's scope was refined: "The number of UMWA locals and Church of God (Cleveland, Tennessee) congregations in these coal field communities grew at the same rate during the 1920s and 1930s. Is there a connection?” Szpack's data indicated that a clear link existed between the growth of labor unions and the Pentecostal Church of God did exist and could be proven with a bit more digging.

As this dissertation illustrates, the real story behind the Harlan County mine wars is one of a grass roots movement in which everyday people, their churches, and preachers, did not lose hope. Until the passage of New Deal legislation such as Section 7 (a) of the National Industrial Recovery Act and the Wagner Act protected workers' right to organize and bargain collectively, company domination, kept the union

\footnotetext{
${ }^{1}$ John B. Holt, "Holiness Religion: Cultural Shock and Social Reorganization” American Sociological Review5 (October 1940), 740, 742.
} 
was establishing a permanent beachhead in these coal towns. In time, the Scriptures provided justification for miners’ belief and involvement in the labor movement and resources located within the numerous mountain churches scattered throughout the county kept their hope for a union alive. In spite of overwhelming operator opposition, the miners of Harlan County kept the union fires burning, until the federal government stepped in to provide "fire insurance" in the form of New Deal legislation, the La Follette Senate hearings, and legal action instituted by the Justice Department. In the interim, the United Mine Workers Union regularly entered and exited the field when it was expedient.

The real workers behind the labor movement were local miners and miner preachers, and international organizers, including George Titler, provided the window dressing for the final, victorious act. Local men were at the forefront of organizing drives from the beginning. A cadre of miner preachers and other miners who were members of their congregations led the way, preaching and practicing a working class theology that promoted trade unionism and the rights of the working man. Miner such as Findley Donaldson, Benjamin Harrison Moses, Marshall Musick, William Clontz, and Hamp Wooten believed that God called them to minister the Gospel of Jesus Christ and Trade Unionism. To these men, serving their fellow man, whether through their church or local union, was part of their Christian duty, a duty that they performed out of love. As preachers, local union officers, and organizers, they served as leaders of the working poor. In doing so, they were practicing the tenets of liberation theology, a theology that, as this dissertation demonstrates, was practiced in the mountains of Appalachia long before it became the solution to the poverty and oppression in Latin America. The miner preachers and their congregations' literal interpretation of the Bible upheld their belief in 
the right to revolt in order to achieve true economic, social, and political justice in the coal fields. The word of God sanctified their revolution, and the Holy Spirit empowered the miners to go up against the coal field elite who considered them outsiders on two counts: as miners and as Holy Rollers.

The various mountain churches scattered throughout the coal camps and towns provided other, more visible resources as well. Besides the leadership provided by miner preachers, these churches provided miners, regardless of race, ethnicity, or religious affiliation, with free spaces where they could gather to receive instruction and information from union officials, hold union meetings and political rallies for pro union candidates, and establish aid distribution during strikes. Equally important was the plausibility of belief that resulted from the fellowship of believers, whether they were gathering for prayer meetings, worship services, or rallies. In all three cases, miner preachers stood in the pulpit, at the pit mouth, and on the picket line praying for victory and encouraging the weary to maintain their faith in God's Promises. In turn, their belief spread throughout the mining community and infected miners regardless of their religious orientation.

The stories of these miner preachers and their tiny churches give us a new, more vibrant portrait of mountain religion. For nearly a century, the American public and mainstream Protestantism in particular, has insisted that the religious beliefs and practices of mountain people are antiquated and factors in the region's chronic poverty. In doing so, a long line of scholars, journalists, ministers, missionaries, and social workers painted a portrait of mountain life and culture, especially in terms of its religion, in lifeless shades of gray, beige, and black, the colors found in cemetery headstones. One of the goals of 
this dissertation was to create a new painting of mountain religion, one that reflected the religious beliefs of a group of people whose religion empowered them. The mountain churches of Harlan County were more concerned with the plight of mining families than their preservation. Instead of serving as an apology and legitimation of the status quo, their religion served as a means of protest, change, and liberation. To this end, they yielded to the leading of the Holy Spirit and the teachings of Scripture and diligently worked to establish the United Mine Workers Union in Harlan County. Armed with the Word of God, the power of the Holy Spirit, and, occasionally, a Smith and Wesson revolver, the miners willingly engaged in a revolution that more than a few perceived as a holy war. These believers kept their eyes on heaven, but this did not mean that they accepted the conditions of the present. The stories of B.H. Moses, Marshall Musick, William Clontz, and Hamp Wooten provide us with a new portrait of the religious landscape, one that is full of vibrant colors that point to the inherent power in religion, one that includes deep shades of red for the sacrifices and blood shed during the reign of terror; purple, to represent the miners’ devotion to their Lord, labor’s first organizer; brilliant white, standing for the conversions to the cause of trade unionism; working man blue; and the color of so many things in nature (and money), green. 


\section{BIBLIOGRAPHY}

\section{Archival Collections}

Berea College, Berea College. Berea, Kentucky.

Southern Appalachian Archives,

Appalachian Religious Survey Records, 1931.

John W. Hevener Collection

Harlan Struggles Manuscript Collection

Dixon Pentecostal Research Center, Lee University, Cleveland, Tennessee.

Church of God (Cleveland, Tennessee) Records

Church of God General Assembly Minutes, 1906-2002. (2006; CD-Rom)

National Archives and Records Administration, Washington, D.C., Microfilm Division. U.S. Census.

Paterno Library, Pennsylvania State University, State College, Pennsylvania

Historical Collections and Labor Archives

United Mine Workers of America Manuscript Collection.

South East Community College, Cumberland, Kentucky.

Appalachian Archive:

Benham and Lynch Manuscript Collection

Oral History Project

State Historical Society of Wisconsin. Madison, Wisconsin.

Miles W. Horton Papers

\section{University of Kentucky, Special Collections, Lexington, Kentucky.}

George Titler Papers

Herndon Evans Papers

\section{Personal Collections}

Oral Histories from the Oral History Collection of Alessandro Portelli, Rome, Italy.

Miles Horton, 15 July 1987

Deborah Spicer, 10 October 1988

\section{Unpublished Materials in the Author's Possession}

Personal Correspondence and Telephone interviews.

Ball, Doris. Telephone interview with Author, 24 May 2005.

Barkey, Fred. Telephone interview with Author, 15 February 2000.

Bosch, William. Correspondence with Author, 2005-2006.

Moses, Larry. Correspondence and Telephone interviews with Author, 2005-2006.

Moses, Mildred. Correspondence and Telephone interviews with Author, 2005. 
Rainey, Marshall. Telephone interview with Author, 7 March 2006.

Szpack, Michael. Correspondence and Telephone interviews with Author, 1999-2005.

Taylor, Paul F., Telephone interview with Author, 25 May 2005.

Wilder, Bernie. Telephone interview with Author, 7 March 2006.

Wooten, Naomi. Correspondence and Telephone interviews with Author, 2005.

\section{United States Government Publications}

U.S. Congress. House. From the Report of the Denhardt Commission. Congressional Record, 74th Cong., 1st sess. (1935), vol. 79, 8987-8988.

U.S. Congress. Senate. Committee on Education and Labor. Violations of Free Speech and Rights of Labor. Hearings before a subcommittee of the Committee on Education and labor on S.R. 266, 75 Congress, 1st session. (1937), Pts. 9-13.

U.S. Department of Commerce. Bureau of the Census. Religious Bodies: 1926. vol. 1-2.

U.S. Department of Commerce. Bureau of the Census. Religious Bodies: 1936. vol. 1-2.

Unpublished Papers in the Author's Possession

Harvey, Paul. "Racial Interchange in Early Southern Pentecostalism,” Paper for Southern Historical Association, November 2001.

Kelly, Brian. "Sentinels for New South Industry: Booker T. Washington, Industrial Accommodation \& Black Working Class Under Jim Crow,” forthcoming in Eric Arnesen, ed. Black Labor and the Fight for Equality

Szpack, Michael.

“Removing the 'Mark of the Beast:' The Church of God and Organized Labor, 1908-1934” (n.d.)

"The Church of God (Cleveland, Tennessee) and the Labor Movement, 1908-1934: A Research Update” (December 21, 1984)

"The Church of God and the Labor Movement: 1907 1935; A Second Research Update” (May 1985)

"The Church of God (Cleveland, Tennessee) and Its Position Regarding Labor Union Membership: Time for a New Direction?” (October 1992)

\section{Journals and Periodicals}

Church of God Evangel

Coal Age

United Mine Workers Journal 


\section{Newspapers}

Harlan Daily Enterprise

Knoxville News-Sentinel

Louisville Courier-Journal

Middlesboro

New York Times

Pineville Sun

Tri-City News

Wheeling Majority

\section{Articles, Books, and Theses}

Albanese, Catherine L. Religions and Religion. Belmont, California: Wadsworth Publishing, 1981.

An Open Letter to Ministers of the Gospel. Washington, D.C.: The American Federation of Labor, n.d.

Ayers, Edward. L. The Promise of the New South: Life After Reconstruction. New York: Oxford University Press, 1992.

Bailey, Kenneth R. “A Judicious Mixture: Negroes and Immigrants in the West Virginia Mine Wars, 18880-1917.” West Virginia History 34 (January 1973): 141-161.

Barb, John A. "Strikes in the Southern West Virginia Coal Fields, 1912-1922.” M.A. thesis, West Virginia University, 1949.

Barkey, Frederick A. “The Socialist Party in West Virginia from 1898 to 1920: A Study in Working Class Radicalism.” Ph.D., dissertation. University of Pittsburgh, 1979.

Beaty, James M. "The First Twenty-One Years of the Church of God.” $<$ http://www.ChurchofGod.cc/resources/heritage/First/Years.Pdf (12 January 2006)

Beik, Mildred Allen . The Miners of Windber: The Struggle of New Immigrants for Unionization, 1890s - 1930s. University Park: The Pennsylvania State University Press, 1996.

Billings, Dwight B. "Religion as Opposition: A Gramscian Analysis,” American Journal of Sociology, 96 (July 1990): 1-31.

Billings, Dwight B.,and Shaunna L.Scott. "Religion and Political Legitimation,” Annual Review of Sociology 20 (1994): 173-176. 
Bishop, Bill. “1931: The Battle of Evarts.” From "Special Report: Harlan County, 1931-1976,” Southern Exposure (4: No. 1-2): 90-114.

Bosch, Bill. "How Did We Get Here?” http://www.home.earthlink.net/ audra-bill/bio.htm> (12 January 2006)

----- "Coal Towns in Harlan County" $<$ http://www.home.earthlink.net/ audra-bill/towns.html> (4 June 2005)

Bubka, Tony. "The Harlan County Coal Strike of 1931.” In Hitting Home: The Great Depression in Town and Country, Bernard Sternsher, ed. Chicago: Quadrangle Books, 1970.

Bunker, Thomas. "Civil War in Harlan,” Class Struggle June 1931. $<$ http://www.weisbord.org/OneTwo.htm> (4 May 2006)

Burchett, Michael H. "Promise and Prejudice: Wise County, Virginia, and the Great Migration, 1910-1920.” Journal of Negro History 82 No. 3 (1997): 312326.

Bush, Bush. "Religious Fervor in the Fairmont Field: Calls for Revival and Reform in the 'Coal City,' 1908-1929.” < http://are.as.wvu.edu/cbush.htm> (14 July 2006)

Butler, Jon and Harry Stout, eds. Religion in American History: A Reader. New York and Oxford: Oxford University Press, 1998.

Callahan, Richard J. "Working With Religion: Industrialization and Resistance in the Eastern Kentucky Coal Fields, 1910-1932.” Ph.D., dissertation, University of California-Santa Barbara, 2002.

Cantrell, Doug. "Immigrants and Community in Harlan County, 1910-1930." Register of the Kentucky Historical Society 86 No.1 (1988) : 119-141.

Cardill, Harry M. Night Comes to the Cumberlands: A Biography of Depressed Area Boston and Toronto: Little, Brown, and Company, 1963

----- Theirs Be the Power: The Moguls of Eastern Kentucky. Urbana and Chicago: University of Illinois Press, 1983.

Carson, Roy. "Coal Industry in Kentucky (As of December, 1960)," A paper given before the Filson Club, 5 December 1960. The Filson Club History Quarterly 40 (1966): 29-42.

Corbin, David A. Life, Work, and Rebellion: The Southern West Virginia Miners, 1880-1922. Urbana: University of Illinois Press, 1981. 
Cressey, Paul Frederick. "Social Disorganization and Reorganization in Harlan County, Kentucky,” American Sociological Review 14 (June 1949): 389-394.

Crews, Mickey. The Church of God: A Social History. Knoxville: The University of Tennessee Press, 1990.

Dotson, John A. "Socio-economic Background and Changing Education in Harlan County, Kentucky.” Ph.D., dissertation, George Peabody College for Teachers, 1934.

Dubofsky, Melvin and Foster Rhea Dulles. Labor in America: A History, $6^{\text {th }}$ ed. Wheeling, Illinois: Harlan Davidson, Inc., 1999.

DuBois, W.E.B. The Souls of Black Folk, David W. Blight and Robert GoodingWilliams, eds. Boston and New York: Bedford Books, 1997.

Duke, David C. Writers and Miners: Activism and Imagery in America. Lexington: The University Press of Kentucky, 2002.

Dunn, Durwood. Cades Cove: The Life and Death of A Southern Appalachian Community, 1818-1937. Knoxville: University of Tennessee Press, 1988.

Eller, Ronald D. Miners, Millhands, and Mountaineers: Industrialization of the Appalachian South, 1880-1930. Knoxville: University of Tennessee Press, 1982.

Fones-Wolf, Elizabeth and Ken. "Trade-Union Evangelism: Religion and the AFL in the Labor Forward Movement, 1912.” Working-Class America: Essays on Labor, Community, and American Society, ed. Michael H. Frisch and Daniel J. Walkowitz. Urbana: University of Illinois Press, 1983.

Fones-Wolf, Ken. "Revivalism and Craft Unionism in the Progressive Era: The Syracuse and Auburn Labor Forward Movements of 1913” New York History 63 (October 1982): 388-416.

----- Trade Union Gospel: Christianity and Labor in Industrial Philadelphia, 18651915. Philadelphia: Temple University Press, 1989.

Fones-Wolf, Ken and Ronald L. Lewis, ed., Transnational West Virginia: Ethnic Communities and Economic Change, 1840-1940. Morgantown: West Virginia University Press, 2002.

Garland, James. Welcome the Traveler Home, Julia S. Ardery, ed. Lexington: The University Press of Kentucky, 1983.

Gaventa, John. Power and Powerlessness: Quiescence and Rebellion in an Appalachian Valley. Urbana and Chicago: University of Illinois Press, 1980. 
Gompers, Samuel. “Editorial.” American Federationist (October 1912), 828-831.

Grammich, Clifford, Jr. Local Baptists, Local Politics: Churches and Communities in the Middle and Uplands South. Knoxville: The University of Tennessee Press, 1999.

Gramsci, Antonio. Selection from the Prison Notebooks, edited and translated by Quintin Hoare and G.N. Smith. New York: International, 1971.

Gutman, Herbert G. Essays in American Working Class and Social History. New York: Vintage Books, 1977. ----- Protestantism and the American Labor Movement: The Christian Spirit in the Gilded Age.” The American Historical Review 72 (1966): 74-101.

Guttierez, Gustavo and Richard Schaull. Liberation and Change, Ronald H. Stone, ed., Atlanta: John Knox Press, 1977.

Hennen, John C. The Americanization of West Virginia: Creating the Modern, Industrial State, 1916-1935. Lexington: The University of Kentucky Press, 1996.

Hevener, John W. Which Side Are You On? The Harlan County Coal Miners, 19311939. Lexington: University Press of Kentucky, reprint, 2002.

Heyrman, Christine L. Southern Cross: The Beginning of the Bible Belt. Chapel Hill-London: The University of North Carolina Press, 1997.

Hickson, Peter C. "History of the Church of God Colored Work," http://www.faculty.leeu.edu/ drc/BlackMinistry/earlyworks.htm $<3 / 2 / 2006>$

Hill, Samuel S., ed., Varieties of the Southern Religion Experience, Samuel S. Hill, ed., Baton Rouge and London: The Louisiana University Press, 1988.

Hopkins, Howard C. The Rise of the Social Gospel in American Protestantism, 1865-1915. New Haven: Yale University Press, 1940.

Hudson, Winthrop S. and John Corrigan. Religion in America: A Historical Account of the Development of American Religious Life. $6^{\text {th }}$ ed. Upper Saddle River, NJ: Prentice-Hall, Inc., 1999.

Ingersoll, Robert Stanley. "Burden of Dissent: Mary Lee Cagle and the Southern Holiness Movement.” Ph.D. dissertation. Department of Religion, Duke University, 1989.

Isaacs, Barbara. "Kentucky Writers Speak Out Against Mountaintop Removal,” Lexington Herald-Leader, posted 14 April 2006 $<$ http://.www.kentucky.com/mld/Kentucky/news/state/14414398.html> (May 4, 2006) 
Kehl, Timothy H. “The Protestant Church and the Labor Movement, 1877-1920.” Master’s thesis. Chicago: Chicago Theological Seminary, June 1973.

Kelemen, Thomas A. “A History of Lynch, Kentucky, 1917-1930.” Ph.d., dissertation. University of Kentucky, 1972.

Lacour, Lawrence Leland. "A Study of the Revival Methods in America, 1920-1955, With Special Reference to Billy Sunday, Aimee Semple McPherson, and Billy Graham.” Ph.D., dissertation. School of Speech, Midwestern University, 1956.

Laing, James T. “The Negro Miner in West Virginia,” in Blacks in Appalachia. William J. Turner and Edward J. Cabbell, ed. Lexington: University of Kentucky Press, 1985, 71-79.

Lewis, Ronald L. Black Coal Miners in America: Race, Class, and Community Conflict, 1780-1980. Lexington: University of Kentucky Press, 1987.

Livingston, William John Bryant. "Coal Miners and Religion: A Study of Logan County, West Virginia.” Ph.D., dissertation, Union Theological Seminary, 1951.

Lofland, John, and Rodney Stark, "Becoming a World-Saver: A Theory of Conversion to a Deviant Perspective” American Sociological Review 30 (June 1965): 862-875.

May, Henry F. Protestant Churches and Industrial America (New York: Harper \& Brothers, Publishers, 1949.

McCauley, Deborah Vansau. Appalachian Mountain Religion: A History. Urbana and Chicago: University of Illinois Press, 1995.

Miles, Emma Bell. Spirit of the Mountains, a facsimile edition. Knoxville: The University of Tennessee Press, 1975.

Miller, Robert Moats. American Protestantism and Social Issues, 1919-1939. Chapel Hill: The University of North Carolina Press, 1958.

Morgan, Louis F. "Bishop J.H. Curry: An Eminent Church Leader." Church of God History and Heritage, Winter/Spring 2003) http://www.faculty.leeu.edu/drc/BlackMinistryExhibit/CurryArticle.htm (2 March 2006)

National Committee for the Defense of Political Prisoners. Harlan Miners Speak: A Report on Terrorism in the Kentucky Coal Fields. Reprint. New York: Da Capo Press, 1970. 
National Endowment for the Humanities. On Dark and Bloody Ground: An Oral History of the U.M.W.A. in Central Appalachia, 1920-1935. Charleston, WV: The Miners' Voice, 1973.

Niebuhr, Reinhold. "Religion and Class War in Kentucky.” Christian Century, 18 May 1932: 637-638.

Odum, Howard W. Southern Regions of the United States. Chapel Hill: The University of North Carolina Press, 1936.

Padgett, Michael. A Godly Heritage: A History of the Church of God, Mountain Assembly. Kearney, Nebraska: Morris Publications, 1995.

Peabody, Frances Greenwood. Organized Labor and Capital: The William L. Bull Lectures for the Year 1904. Philadelphia: G.W. Jacobs and Company, 1904.

Pope, James Gray. "The Western Pennsylvania Coal Strike of 1933, Parts 1,2: Lawmaking from Below and the Revival of the United Mine Workers." Labor History Vol. 44, No.1-2 (1993): 15-48.

----- Lawmaking from Above and the Demise of Democracy in the United Mine Workers.” Labor History, Vol. 44, No. 2 (1993): 235-264.

Pope, Liston. Millhands and Preachers: A Study of Gastonia. New Haven: Yale University Press, 1942.

Portelli, Alessandro. The Death of Luigi Trastulli and Other Stories: Form and Meaning in Oral History. Buffalo: State University of New York Press, 1990.

Ross, Malcom. Death of a Yale Man. New York: Farrar and Rinehart, 1939.

Roebuck, David G. "Restorationism and a Vision for World Harvest: A Brief History of the Church of God."

$<$ http://www.ChurchofGod.cc/resources/heritage/Restoratinism.pdf > (January 2006)

Savage, Lon. Thunder in the Mountains: The West Virginia Mine War, 1920-1921. Pittsburgh: University of Pittsburgh Press, 1990.

Scott, Shaunna Lynn. Two Sides to Everything: The Cultural Construction of Class Consciousness in Harlan County, Kentucky. Albany: State University of New York Press, 1995.

Shackleford, Thomas Heflin. "What Can Be Done to Bridge the Gap Between Labor and the Church?” Ph.d., dissertation, Emory University, 1919. 
Shelton, Floyd Bunyon. "An Investigation of the Social Life of a West Virginia Coal Field.” Bachelor’s thesis, Emory University, 1920.

Shifflett, Crandall. Coal Towns: Life, Work, and Culture in Company Towns in Southern Appalachia, 1880-1960. Knoxville: University of Tennessee Press, 1994.

Smith, Timothy L. Revivalism and Social Reform: American Protestantism on the Eve of the Civil War (Baltimore and London: The John Hopkins University Press, 1980

Stelzle, Charles. The Church and the Labor Movement. Philadelphia: American Baptist Publication Society, 1911.

Stout, Harry S. and D.G. Hart., eds. New Directions in American Religious History New York: Oxford University Press, 1997.

Synan, Vinson. The Holiness-Pentecostal Tradition: Charismatic Movements in the Twentieth Century, $2^{\text {nd }}$ ed: Grand Rapids Michigan: William B. Eerdsman Publishing Company, 1997.

Szpack, Michael. "Removing the 'Mark of the Beast': The Church of God (Cleveland, Tennessee) and Organized Labor, 1908-1934” Labor’s Heritage (Summer 1994)

Tankel, Phillip. "Bloody Harlan in 1931-1939: An Appalachian Coal County in the Thirties.” Honors Thesis, Brandeis University, 1968.

Taylor, Paul. Bloody Harlan: The United Mine Workers in America in Harlan County, Kentucky, 1931-194. Lanham: University Press of America, 1990.

----- “Coal and Conflict: The UMWA in Harlan County, 1931-1939.” Ph.d., diss., University of Kentucky, 1969.

----- The Church of God in Kentucky: A History, 1911-1988. Charlotte, North Carolina: The Delmar Company, 1988.

“The Revolt of the Miners,” Harry F. Ward, Winifred L. Chappell, eds. The Social Service. New York: The Methodist Federation for Social Services, 1931.

Titler, George J. Hell in Harlan. Charleston: BJW Printers, 1972.

Trotter, Joe William. Coal, Class, and Color: Blacks in Southern West Virginia, 1915-1932. Urbana: University of Illinois Press, 1990.

The Church of God of Kentucky, A History, 1911-1987 Charlotte, N.C: Delmar, 1988. 
Wagner, Thomas E. and Phillip J. Obermiller. Appalachian Migrants and Miners: The Eastern Kentucky Social Club. Urbana and Chicago: University of Illinois Press, 2004.

Ward. Harry F., and Winifred L. Chappell, ed.. "The Revolt of the Miners." New York: The Methodist Federation for Social Services, 1931.

Weber, Max. The Protestant ethic and the Spirit of Capitalism. New York: Charles Scribner's Sons, 1958.

Wickersham, Edward Dean. "Opposition to the International Officers of the UMWA, 1919-1913,” Ph.D., diss. Cornell University, 1951.

Wolfe, Margaret Ripley. "Alienation in Southern Appalachia: Catholics in the Coal Camps, 1900-1940.” Appalachian Heritage 6 (1978): 43-56.

----- "Wooten Family Heritage."

http://www.pawsofpa.com/wooten_family_heritage.html> (4 May 2006) 